\title{
Analysis of the World \\ Distribution of Metal-Rich Subsea Manganese Nodules
}




\section{Analysis of the World Distribution of Metal-Rich Subsea Manganese Nodules}

By V. E. McKelvey, Nancy A. Wright, and Roger W. Bowen

GEOLOGICAL SURVEY CIRCULAR 886 


\section{United States Department of the Interior}

JAMES G. WATT, Secretary

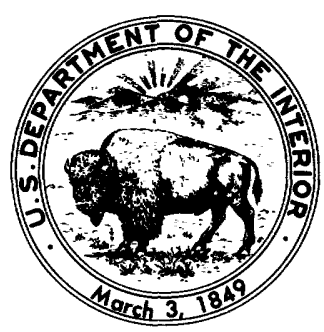

\section{Geological Survey}

Dallas L. Peck, Director

\section{Library of Congress Cataloging in Publication Data}

McKelvey, V. E. (Vincent Ellis), 1916-

Analysis of the world distribution of metal-rich subsea manganese nodules.

(Geological Survey circular ; 886)

Bibliography: p. 53

Supt. of Docs. no.: I 19.4/2:886

1. Manganese nodules. I. Wright, Nancy A. II. Bowen, Roger W. III. Title. IV. Series.

QE75.C5 no. 886557.3 s [553.4'629] $82-600335$

[QE390.2.M35] 


\section{CONTENTS}

Abstract
World average metal content of manganese nodules
Average metal content of nodules in each of the oceans
World average metal content of nodules in latitudinal zones
Relation of metal content of nodules to water depth
Relation of nodule concentration to water depth
Metal-rich types of manganese nodules
Targets for exploration
Other elements in manganese nodules
Genetic implications of variations in composition of manganese nodules
$\quad$ Relation of metal content to mineralogy
$\quad$ Relation to water depth
Effects of direct precipitation from seawater in comparison with diagenetic precipitation -
Relation to regional variations in sediment type, biologic productivity, and physiography -
Summary -- cited
References cions

\section{ILLUSTRATIONS}

1. Map showing manganese nodule stations in the Scripps Institution of Oceanography's Sediment Data Bank as of March 1980

2-13. Diagrams showing relations between:

2. Manganese.content in manganese nodules and their latitudes at stations in the Scripps Institution of Oceanography's Sediment Data Bank

3. Combined nickel and copper content in manganese nodules and their latitudes at stations in the Scripps Institution of Oceanography's Sediment Data Bank

4. Depth and combined nickel and copper content in manganese nodules at stations in the Scripps Institution of Oceanography's Sediment Data Bank

5. Depth and cobalt content in manganese nodules in the Scripps Institution of Oceanography's Sediment Data Bank

6. Depth and combined nickel and copper in Pacific Ocean manganese nodules at 1,770 stations in the Scripps Institution of Oceanography's Sediment Data Bank

7. Depth and combined nickel and copper content in Atlantic Ocean manganese nodules at 296 stations in the Scripps Institution of Oceanography's Sediment Data Bank

8. Depth and combined nickel and copper content in Indian Ocean manganese nodules at 300 stations in the Scripps Institution of Oceanography's Sediment Data Bank

9. Depth and cobalt content in Pacific Ocean manganese nodules at 1,710 stations in the Scripps Institution of Oceanography's Sediment Data Bank

10. Depth and cobalt content in Atlantic Ocean manganese nodules at 285 stations in the Scripps Institution of Oceanography's Sediment Data Bank

11. Depth and cobalt content in Indian Ocean manganese nodules at 289 stations in the Scripps Institution of Oceanography's Sediment Data Bank

12. Depth and manganese content in manganese nodules at stations in the Scripps Institution of Oceanography's Sediment Data Bank

13. Depth and concentration of manganese nodules at stations in the Scripps Institution of Oceanography's Sediment Data Bank 
14-18. Maps showing distribution of manganese nodules containing:

14. 1.8 percent combined nickel and copper or more

15. 1.0 or more and less than 1.8 percent combined nickel and copper

16. 1.0 percent cobalt or more

17. 0.5 or more and less than 1.0 percent cobalt

18. 35.0 percent manganese or more

19-21. Maps showing distribution of manganese nodules having high metallic contents in:

19. Pacific Ocean

20. South Atlantic Ocean

21. Indian Ocean

22-28. Maps showing target areas for exploration for manganese nodules rich in combined nickel and copper in:

22. Central northeastern Pacific Ocean

23. Central north equatorial Pacific Ocean

24. Southeastern equatorial Pacific Ocean

25. Central southeastern Pacific Ocean

26. Central South Pacific Ocean

27. Central south equatorial Indian Ocean

28. Southeastern Indian Ocean

29. Ternary plot of principal mineral phases of manganese nodules at 107 stations in the Scripps Institution of Oceanography's Sediment Data Bank for which analyses of all constituents shown have been made

\section{TABLES}

TABLE 1. World metal contents, nodule concentrations, depths, and metal ratios of manganese nodules

2. Comparison of the world average metal contents of manganese nodules listed in table 1 with the values reported by Cronan (1980)

3. Metal contents, concentrations, depths, and metal ratios of manganese nodules in the Pacific, Atlantic, and Indian Oceans

4. Average metal contents of manganese nodules, by ocean

5. Some metal ratios in manganese nodules in comparison with those in the Earth's crust and seawater

6, 7. Metal contents, concentrations, depths, and metal ratios of manganese nodules, grouped by latitude, in:

6. Northern hemisphere

7. Southern hemisphere

8. World average and maximum metal contents of manganese nodules, categorized by latitude

9-11. Average and maximum metal contents of manganese nodules, categorized by latitude in:
9. Pacific Ocean
10. Atlantic Ocean
11. Indian Ocean

12. Metal contents, concentrations, depths, and metal ratios of manganese nodules in water depths of less than 2,000 and more than $4,000 \mathrm{~m}$

13. Metal contents of manganese nodules in water depths above and below $3,000 \mathrm{~m}$

14-16. Metal contents, concentrations, depths, and metal ratios of manganese nodules containing:

14. 1.0 percent combined nickel and copper or more

15. 1.0 percent combined nickel and copper or more outside the Clarion-Clipperton zone

16. More than 0.5 percent cobalt and more than 35 percent manganese

17-20. Other elements in manganese nodules:

17. Of the world and of the Pacific, Atlantic, and Indian Oceans

18. Means of the world, grouped by latitude

19. Means in water depths above and below $3,000 \mathrm{~m}$

20. Grouped by combined nickel and copper, manganese, and cobalt contents

21. World means and ocean maximums of several other elements in manganese nodules that have exceptionally high concentrations 


\title{
Analysis of the World Distribution of Metal-Rich Subsea Manganese Nodules
}

\author{
By V. E. McKelvey,' Nancy A. Wright,, ${ }^{2}$ and Roger W. Bowen
}

\begin{abstract}
Publicly available data on the composition of subsea manganese nodules extend previous reports of differences in average metal contents from ocean to ocean and of variations related to latitude and depth. Pacific Ocean nodules have the highest average manganese, nickel, and copper contents, and Atlantic Ocean nodules have the highest average iron content. The average manganese, nickel, and copper contents generally increase toward the equator in both hemispheres, and iron content generally decreases. The variation of metal content with water depth is not linear; instead, there appears to be a threshold depth of about 2,900 to $3,000 \mathrm{~m}$, above which combined nickel and copper contents are generally less than 1 percent and below which cobalt content is generally less than about 0.6 percent.

The composition of the nodules varies widely, but three rarely overlapping types that are of possible economic interest can be recognized. (1) Nodules containing more than about 1 percent combined nickel and copper only exceptionally contain more than 0.5 percent cobalt and 35 percent manganese. (2) Nodules containing more than 0.5 percent cobalt rarely contain more than 1 percent combined nickel and copper and 35 percent manganese. (3) Nodules containing more than 35 percent manganese only exceptionally contain more than 0.5 percent cobalt, although they average nearly 1.1 percent combined nickel and copper. Current economic interest in nodule mining is focused on the ClarionClipperton zone in the northeastern equatorial Pacific Ocean, the largest known area in which nodules average 1.8 percent or more combined nickel and copper. Several other areas in which nodules are rich in these metals are found in the Pacific and Indian Oceans and may be viewed as targets for exploration.

Nearly 60 chemical elements have been found in manganese nodules, many in concentrations far exceeding their crustal abundances. The amounts in which many minor elements are present vary with the amounts of principal metals present, but the three metal types described above do not include the maximum reported values for several other elements, such as titanium (8.9 percent), vanadium (0.5), zinc (9.0), and lead (0.75). It seems possible, therefore, that there may be other kinds of metal-rich types, some of which may have pötential economic value.
\end{abstract}

1U.S. Geological Survey, retired.

2 Deceased.
Many of the variations in nodule composition are in large part a function of variations in mineral composition, to which many factors contribute. Some of the regional variations can be broadly related to oceanic circulation, basin morphology, and depth, but a better understanding of ocean processes and regional oceanography and geology is needed to explain all the variations observed in the composition of manganese nodules.

\section{INTRODUCTION}

Through the good offices of J. Z. Frazer, we have entered in the U.S. Geological Survey computer in Reston, Va., all data on subsea manganese nodules in the Scripps Institution of Oceanography's Sediment Data Bank, which includes all published and otherwise publicly available analyses of manganese nodules, reported on or converted to a water-free basis (for a description of the bank, see Frazer and Fisk (1980)). We are thus able to analyze variations in nodule composition related to geographic distribution, water depth, and other factors and to identify areas in which the metal content of available samples is high enough to justify further exploration for deposits that might someday be suitable for mining. The results reported here place principal emphasis on variations in manganese, iron, nickel, copper, and cobalt contents (collectively referred to as the "metal content").

\section{WORLD AVERAGE METAL CONTENT OF MANGANESE NODULES}

As of March 1980, the Scripps Sediment Data Bank contained chemical analyses of nodules from 2,401 stations. The metal contents, concentrations, depths, and metal ratios from these stations are summarized in table 1 . Because the stations are irregularly distributed (see fig. 1), even world averages must be regarded as only approximations. More than 400 stations are located in the 


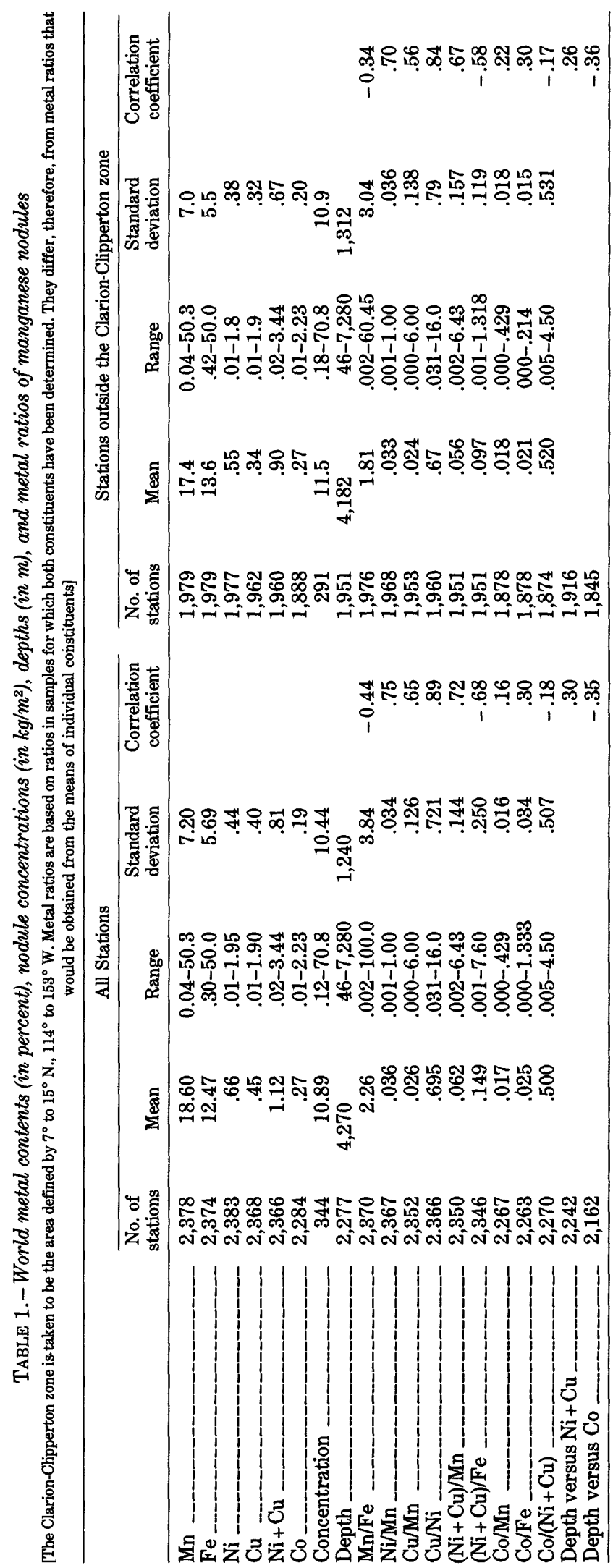




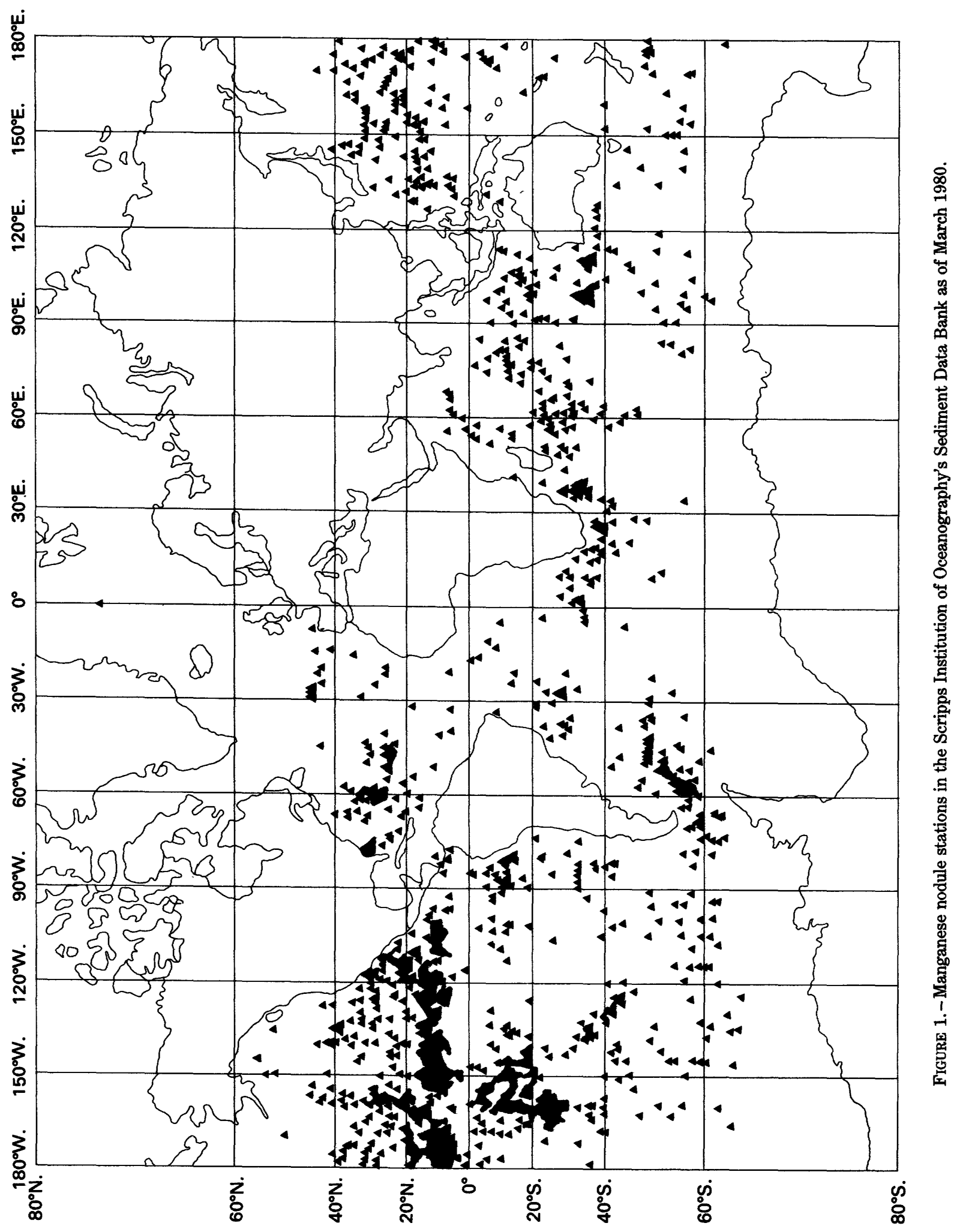


Clarion-Clipperton zone in the northeastern equatorial Pacific-an area of about 2.5 million square kilometers in which nodules average 25.43 percent manganese, 6.66 iron, 1.27 nickel, 1.02 copper, and 0.22 cobalt (McKelvey and others, 1979). Hein (1977) reported almost identical averages for the several thousand samples collected from the Clarion-Clipperton zone by the Centre National pour l'Explotation des Oceans namely 25.56 percent manganese, 6.40 iron, 1.25 nickel, 1.05 copper, and 0.24 cobalt. The disproportionate number of samples there biases the world averages. As the comparison in table 1 shows, exclusion of Clarion-Clipperton zone values from the world averages decreases somewhat the average nickel, copper, and manganese contents, increases iron content, and has no effect on cobalt content. The world averages estimated by Cronan (1980, slightly revised from $1976 ; 1977)$ are even lower in manganese, nickel, and copper and higher in iron and cobalt (table 2). Because more than 70 percent of the stations outside of the Clarion-Clipperton zone are in the Pacific and because the average manganese, nickel, and copper contents of Pacific nodules are higher than those of Atlantic and Indian nodules (table 3), the influence of Pacific samples on the world averages shown in table 1 is considerable. D. Z. Piper (personal commun., 1981) pointed out, however, that nodules are far more abundant in the Pacific Ocean than they are in the Atlantic and Indian Oceans and that the number of Atlantic stations in the Scripps Sediment Data Bank (about 300 in comparison with about 300 Indian stations and nearly 1,800 Pacific stations) may give the Atlantic undue weight in the world average.

\section{AVERAGE METAL CONTENT OF NODULES IN EACH OF THE OCEANS}

Mero (1962), Cronan and Tooms (1969), and Cronan (1977) called attention to the fact that the average manganese, nickel, and copper contents of Pacific nodules are higher than those of Atlantic and Indian nodules. These differences and others are shown in table 3. Even when the ClarionClipperton zone stations are eliminated, Pacific nodules contain 1.38 and 1.2 times as much manganese and 2.36 and 1.5 times as much combined nickel and copper as Atlantic and Indian nodules, respectively. As might be expected, these differences also show up in the maximum values; nodules from the Pacific Ocean contain as much as
TABLE 2.-Comparison of the world average metal content of manganese nodules listed in table 1 with the values reported by Croman (1980)

[The Clarion-Clipperton zone is taken to be the area defined by $7^{\circ}$ to $15^{\circ} \mathrm{N} ., 114^{\circ}$ to $153^{\circ} \mathrm{W}$.]

\begin{tabular}{|c|c|c|c|}
\hline & \multicolumn{2}{|c|}{ Table 1 values (in percent) } & \multirow[b]{2}{*}{$\begin{array}{l}\text { World values } \\
\text { reported by Cronan } \\
\text { (in percent) }\end{array}$} \\
\hline & World & $\begin{array}{l}\text { World excluding } \\
\text { Clarion-Clipperton } \\
\text { zone }\end{array}$ & \\
\hline $\mathbf{M n}$ & 18.60 & 17.45 & 16.174 \\
\hline $\mathrm{Fe}$ & 12.47 & 13.63 & 15.608 \\
\hline $\mathrm{Ni}$ & .66 & .55 & .4888 \\
\hline $\mathrm{Cu}$ & .45 & .34 & .2561 \\
\hline $\mathrm{Ni}+\mathrm{Cu}$ & 1.12 & 0.90 & .7449 \\
\hline Co & .27 & .27 & .2987 \\
\hline
\end{tabular}

50.3 percent manganese and $\mathbf{3 . 4 4}$ percent combined nickel and copper in comparison with maximums of 40.9 and 32.3 percent manganese and 2.3 and 3.24 percent combined nickel and copper for the Atlantic and Indian Oceans, respectively. On the other hand, both the mean and the maximum iron contents are highest for Atlantic nodules -16.97 and 50.0 percent, respectively, in comparison with 14.23 and 39.63 for Indian nodules and 11.4 and 41.9 percent for Pacific nodules. Although the mean cobalt content is the same for nodules from the Pacific and the Atlantic, the maximum in Pacific nodules is 2.23 percent in comparison with 1.44 in Atlantic nodules and 0.94 in Indian nodules. The mean cobalt content of Atlantic nodules is more than twice the mean copper content and is nearly as much as the mean nickel content.

The metal ratios also differ considerably. Not only is the manganese-iron ratio much lower in Atlantic and Indian nodules, but the copper-nickel ratio in Atlantic nodules is also appreciably lower than the copper-nickel ratios in Pacific and Indian nodules. The moderate negative correlation between manganese and iron in Pacific nodules is much weaker in Indian Ocean samples and is nearly absent in Atlantic nodules. The strong positive correlation between nickel and copper and the negative correlation between combined nickel and copper and iron found in the Pacific nodules are weaker in Atlantic and Indian nodules.

For comparison, table 4 shows the ocean averages previously estimated by Mero (1962), Goldberg (1965), and Cronan (1980) along with those from table 3.

The average depth of the nodule stations is about the same in the Pacific and Indian but is nearly $\mathbf{7 0 0}$ $m$ shallower in the Atlantic. No data on concentration are available in the Atlantic; those in the In- 

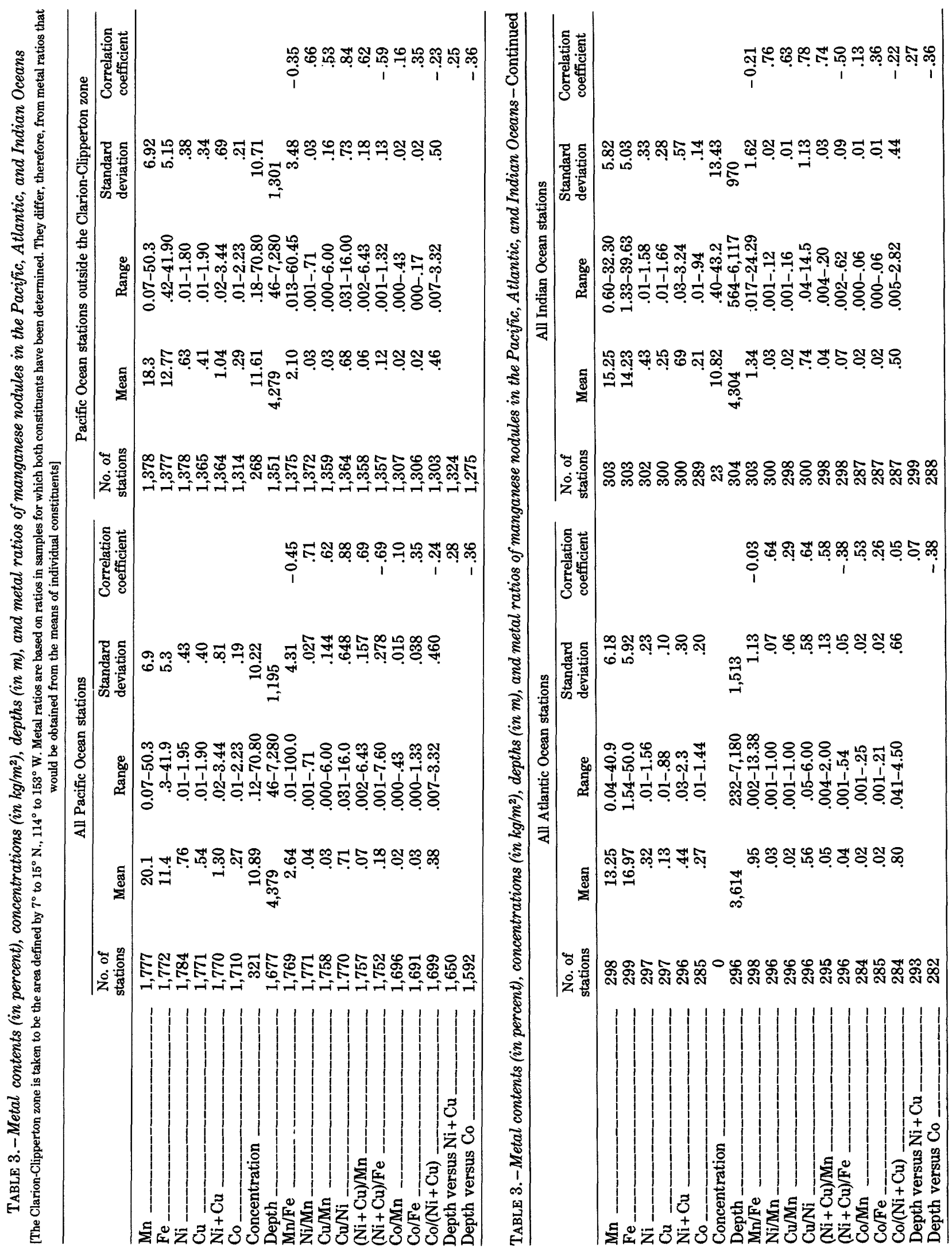
TABLE 4. - Average metal contents of manganese nodules, by ocean

[The Clarion-Clipperton zone is taken to be the area defined by $7^{\circ}$ to $15^{\circ} \mathrm{N}$., $114^{\circ}$ to $153^{\circ} \mathrm{W}$.]

\begin{tabular}{|c|c|c|c|c|c|c|c|c|c|c|}
\hline & \multicolumn{5}{|c|}{ Pacific Ocean } & \multicolumn{3}{|c|}{ Atlantic Ocean } & \multicolumn{2}{|c|}{ Indian Ocean } \\
\hline & $\begin{array}{c}\text { All table } \\
\mathbf{3} \text { stations }\end{array}$ & $\begin{array}{l}\text { Table } 3 \text { stations } \\
\text { minus Clarion- } \\
\text { Clipperton zone }\end{array}$ & $\begin{array}{c}\text { Mero } \\
(1962) \\
\end{array}$ & $\begin{array}{c}\text { Goldberg } \\
(1965)\end{array}$ & $\begin{array}{l}\text { Cronan } \\
(1980)^{1} \\
\end{array}$ & Table 3 & $\begin{array}{c}\text { Mero } \\
(1962) \\
\end{array}$ & $\begin{array}{l}\text { Cronan } \\
\left(^{(1980)^{1}}\right.\end{array}$ & Table 3 & $\begin{array}{l}\text { Cronan } \\
(1980)^{1} \\
\end{array}$ \\
\hline $\mathrm{Fe}$ & 11.4 & 12.77 & 14.0 & 14 & 11.96 & 16.97 & 17.5 & .78 & 14.23 & 14.74 \\
\hline $\mathrm{Ni}$ & .76 & .63 & .99 & .4 & .634 & .32 & .42 & .328 & .43 & .464 \\
\hline $\mathrm{Cu}$ & .54 & .41 & .53 & .5 & .392 & .13 & .20 & .116 & .25 & .116 \\
\hline
\end{tabular}

1 Estimates made on the basis of detrital-free material.

dian Ocean are sparse but, for what they are worth, average about the same as those in the Pacific.

In the Earth's crust as a whole, in most of its common rocks, and in seawater, with few exceptions, $\mathrm{Fe}>\mathrm{Mn}>\mathrm{Ni}>\mathrm{Cu}>\mathrm{Co}$ (Lee and $\mathrm{Yao}, 1970$; Goldberg and others, 1971). Except for means in Atlantic nodules, this relationship holds true also for means of nickel, copper, and cobalt shown in table 3; only in Atlantic nodules, however, is the mean iron content greater than the mean manganese content. As table 5 shows, the average ratios of nickel to cobalt and copper to cobalt in world and Pacific nodules outside the Clarion-Clipperton zone are somewhat similar to those in oceanic crust, although they do indicate a moderate impoverishment of cobalt relative to nickel and copper in the nodules. In seawater and Clarion-Clipperton zone nodules, the mean ratios of nickel to cobalt and copper to cobalt are much higher than those in the Earth's crust or its major subdivisions. The differences between the mean ratios of these metals in nodules and in average Earth's crust are minor, however, in comparison with the difference in the manganese-iron ratios. In the Earth's crust, iron is more than 40 times as abundant as manganese, and, even in seawater, it is $\mathbf{1 . 5}$ times higher. Iron is more abundant than manganese in some nodules also, but only in the Atlantic is the mean iron content of the nodules greater than the mean manganese content. In Clarion-Clipperton zone nodules, the average manganese content is more than four times the average iron content. In comparison with average contents in oceanic crust, world nodule means for nickel, copper, and cobalt are 47,53 , and 73 times greater, respectively, and the mean for manganese is 103 times greater, but that for iron is only 1.67 times larger. The difference between concentrations of iron and other metals in ocean crust and in Clarion-Clipperton zone nodules is even greater. The average manganese, nickel, copper, and cobalt contents in Clarion-Clipperton zone nodules are 141, 91, 120, and 59 times greater, respectively, than their averages in oceanic crust, whereas the iron content is 0.89 times greater than its average in oceanic crust. The iron ratio would be even lower if it were based only on soluble iron, for, according to D. Z. Piper (personal commun., 1981), about 25 percent of the total iron in metal-rich nodules is in insoluble silicates, most of which are very likely of extraneous origin. In marine manganese nodules, many metals are found in concentrations many times higher than their crustal abundances, but iron generally is not one of them; in fact, iron is less abundant in the nodules of greatest current economic interest than it is in oceanic crust.

\section{WORLD AVERAGE METAL CONTENT OF NODULES IN LATITUDINAL ZONES}

It has been known for some time that the subsea manganese nodules richest in nickel and copper are found in the equatorial regions of the Pacific Ocean (Mero, 1962; Horn and others, 1972, 1973; Arrhenius, 1975; Piper and Williamson, 1977; Skornyakova, 1979; Cronan, 1980; Heath, 1981; Exon, 1982), although J. Z. Frazer (written commun., 1980) pointed out that, whereas nodules greatly enriched in copper occur only near the equator, nodules high in nickel occur in many different regions. Hutchinson (1947) also reported a latitudinal zonation of the iron-manganese ratio in surficial sediments of the Atlantic, and Goldberg (1954) found a pronounced dependence of this ratio on latitude in pelagic sediments of the Pacific (see also Skornyakova, 1965; Greenslate, 1975; Piper and Williamson, 1977). Tables 6 and 7 show that the relation between latitude and the metal content of the nodules extends to higher latitudes as 
TABLE 5. - Some metal ratios in manganese nodules in comparison with those in the Earth's crust and seawater

[Crustal values from Lee and Yao (1970). Seawater values from Goldberg and others (1971). Concentrations of manganese, nickel, and copper listed by these authors are much higher than more recent determinations by Bender and others (1977) and Bender and Gagner (1976), who are skeptical about the validity of higher values reported earlier, but these differences seem unlikely to affect sense of comparison of metal ratios shown here. Manganese nodule ratios based on ratios in samples for which both constituents have been determined. They differ, therefore, from metal ratios that would be obtained for means of individual constituents. The Clarion-Clipperton zone is taken to be the area defined by $7^{\circ}$ to $15^{\circ} \mathrm{N} ., 114^{\circ}$ to $153^{\circ} \mathrm{W}$.]

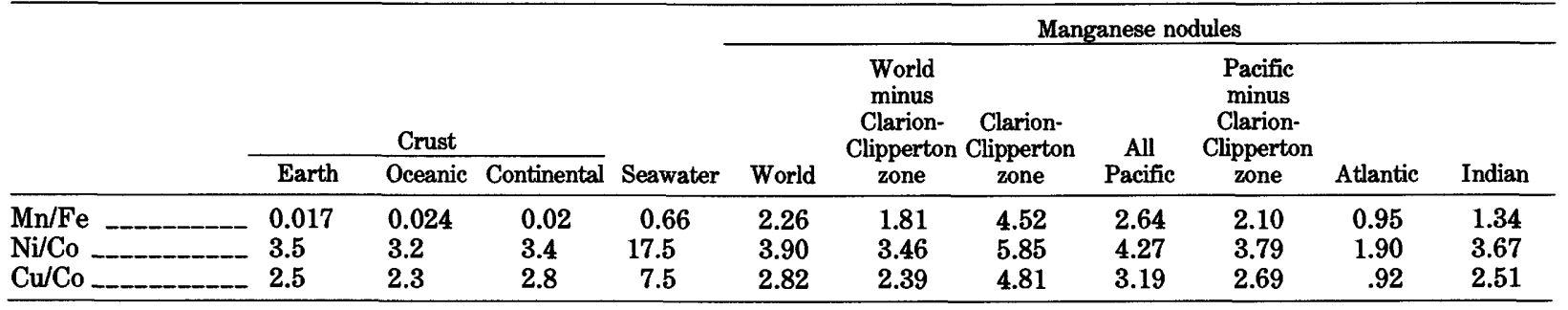

well. These data are summarized in table 8 for easy comparison. The average manganese, copper, and nickel contents generally increase toward the equator in both hemispheres, and iron decreases, although its high is in the $20^{\circ}$ to $40^{\circ} \mathrm{S}$. zone. Cobalt decreases slightly toward the equatorial region in the northern hemisphere but shows the opposite relation in the southern hemisphere. The increase toward the equator holds nearly as well for the maximum values of manganese, nickel, and copper. Curiously, however, the maximum values of iron and cobalt in both hemispheres are between latitudes $20^{\circ}$ and $40^{\circ}$. Although the total metal content also increases toward the equatorial regions in both hemispheres, the difference is relatively small, except below latitude $60^{\circ}$, where the total of the five metals considered is only about 25 percent, an indication that less than half of the nodules are composed of iron and manganese minerals.

The latitudinal relations for manganese and combined nickel and copper are also shown in figures 2 and 3 . These plots show well the increase in these metals toward the equator, but the graphs indicate that their contents decrease rather abruptly in the zone extending a few degrees north and south of the equator, as Piper and Williamson (1977) also showed. The graphs also show a rather curious decrease in manganese and combined nickel and copper between $20^{\circ}$ and $30^{\circ} \mathrm{S}$.

Although the average values for both nickel and copper generally increase toward the equatorial regions (the value for nickel between $40^{\circ}$ and $60^{\circ}$ $\mathrm{S}$. is a slight departure from this trend), the copper-nickel ratios are not uniform (J. Z. Frazer, written commun., 1980). In the northern hemisphere, the copper-nickel ratio increases from an averge of 0.49 between $40^{\circ}$ and $60^{\circ} \mathrm{N}$. to 0.8 in the equatorial region. In the southern hemisphere, it is more erratic; the high average of 0.80 is south of $60^{\circ} \mathrm{S}$. (where nickel and copper values are very low), and the low average of 0.59 is between $20^{\circ}$ and $40^{\circ} \mathrm{S}$. The latitudinal change in the percentages of nickel and copper contents is much greater than that for iron and manganese contents (Skornyakova, 1979).

The world averages are strongly influenced by the large number of Pacific stations, but somewhat similar latitudinal relationships prevail in each ocean (tables 9, 10, and 11). Expectably, the trends for Pacific nodules are essentially the same as those for world averages. Although the data for some Atlantic latitudinal categories are too sparse to justify much confidence in the trends there, the general increase in manganese toward the equator is found in Atlantic nodules, although the highest value in the northern hemisphere is between $40^{\circ}$ and $60^{\circ} \mathrm{N}$. The highest means for nickel and copper are in the $20^{\circ}$ to $40^{\circ}$ range for both hemispheres in the Atlantic, and, although general equatorial increases are shown for these metals in the Pacific and Indian Oceans, slight secondary highs occur in the $40^{\circ}$ to $60^{\circ}$ range in both. The iron content of North Atlantic nodules decreases toward the equator but seems erratic in the South Atlantic. Although iron contents generally decrease toward the equator in the Pacific and Indian Oceans, the highest means are found in the $20^{\circ}$ to $40^{\circ}$ range in both, and the highest value for the world (50 percent) is located in the $20^{\circ}$ to $40^{\circ}$ N. range in the Atlantic.

\section{RELATION OF METAL CONTENT OF NODULES TO WATER DEPTH}

Many previous investigators have reported a relation between nodule composition and water depth (Menard, 1964; Mero, 1965; Barnes, 1967; 

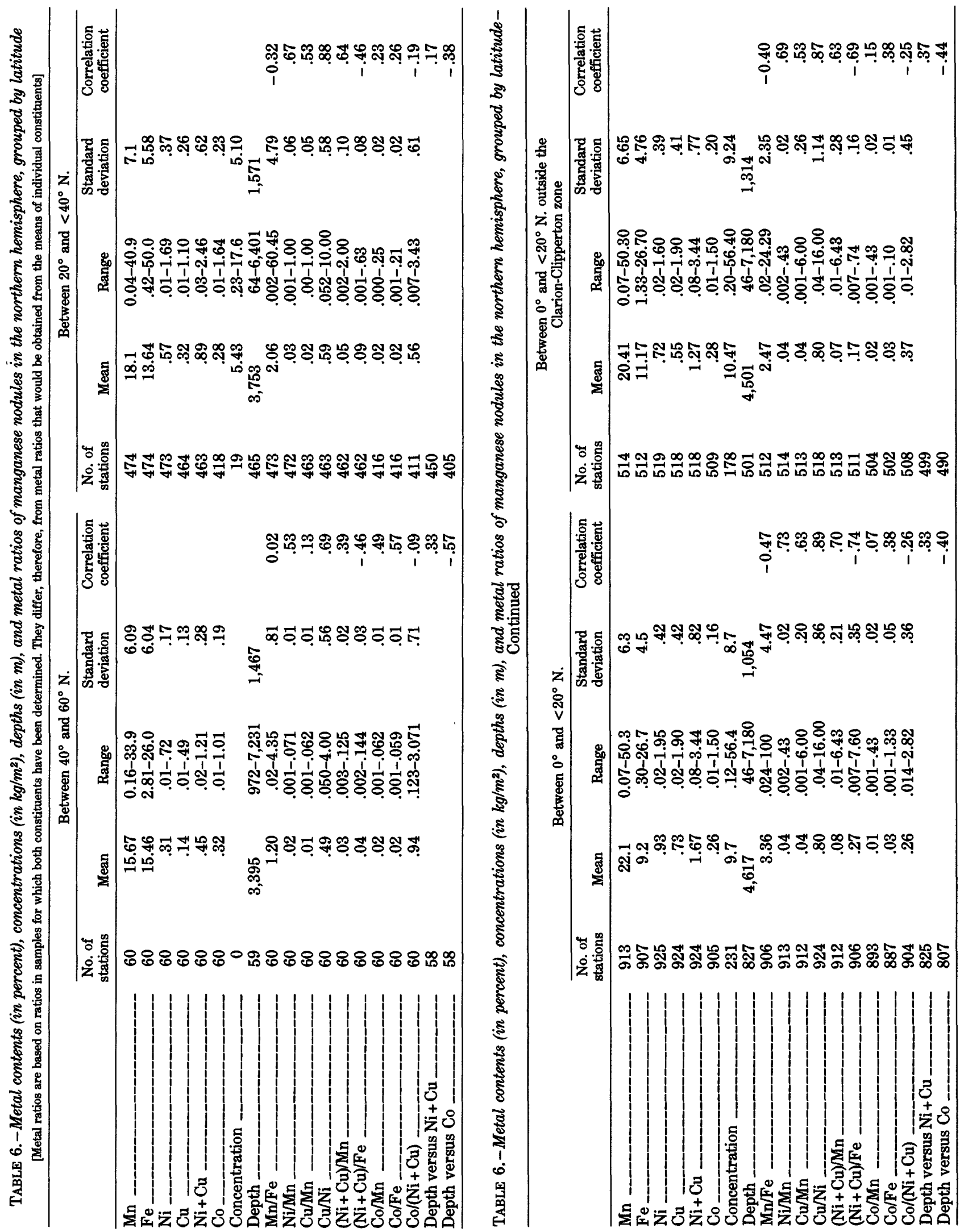

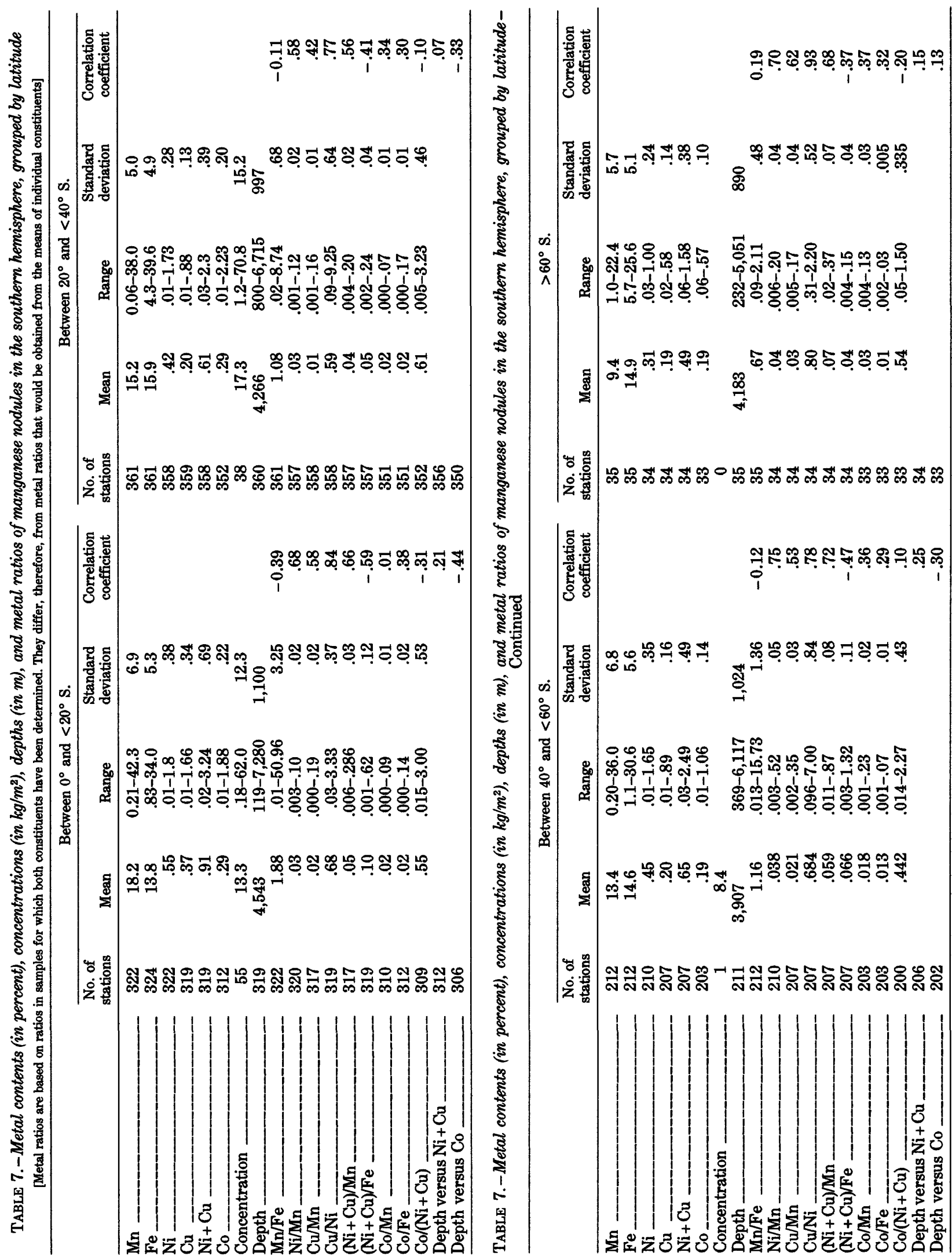


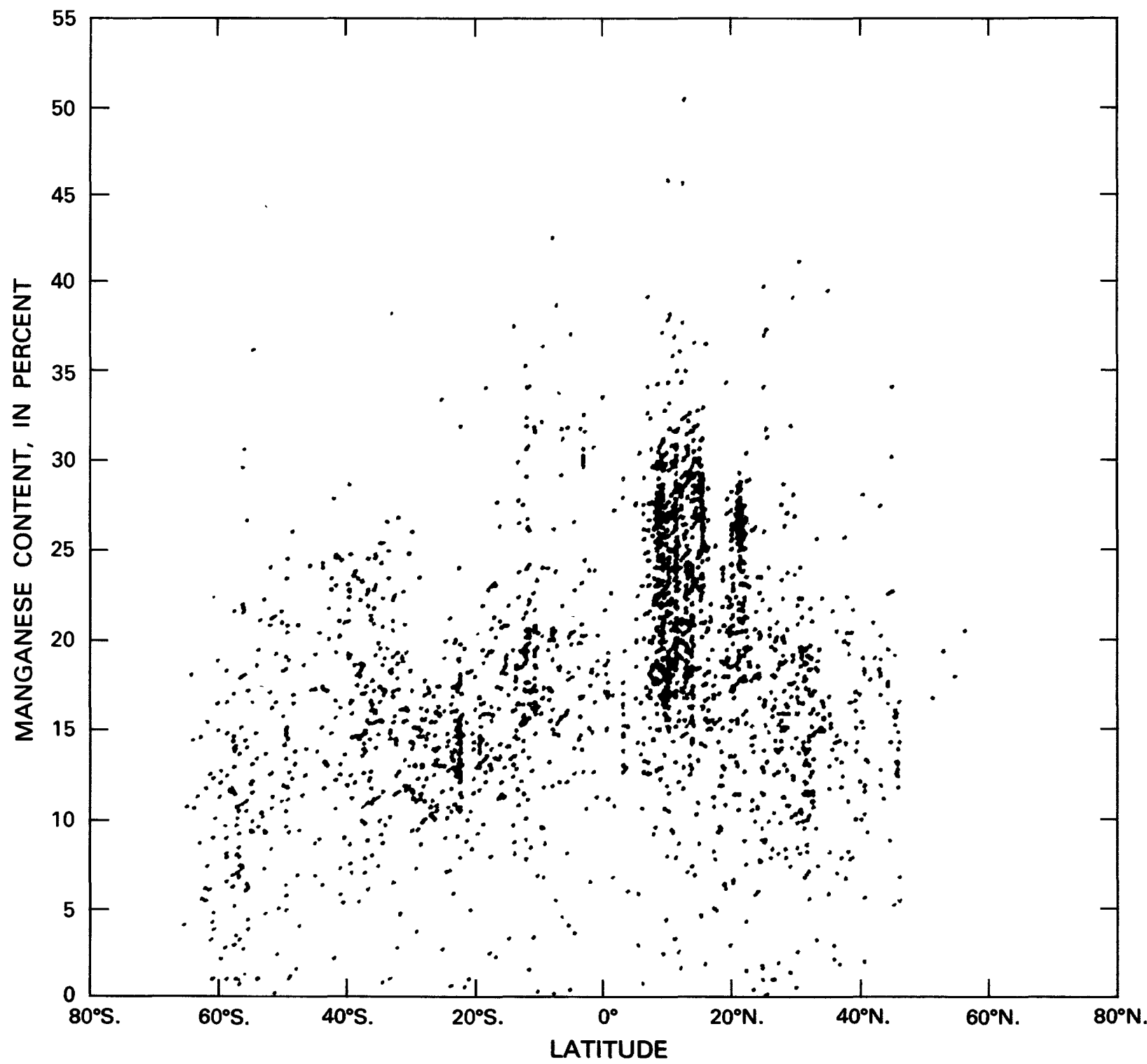

FIGURE 2.-Relation between manganese content in manganese nodules and their latitudes at stations in the Scripps Institution of Oceanography's Sediment Data Bank.

TABLE 8. - World average and maximum (in parentheses) metal contents (in percent) of manganese nodules, categorized by latitude

\begin{tabular}{|c|c|c|c|c|c|c|c|c|}
\hline & $\begin{array}{c}40^{\circ}-<60^{\circ} \\
\text { N. }\end{array}$ & $\begin{array}{c}20^{\circ}-<40^{\circ} \\
\mathrm{N} .\end{array}$ & $\begin{array}{c}0^{\circ}-<20^{\circ} \\
\text { N. }\end{array}$ & $\begin{array}{c}0^{\circ}-<20^{\circ} \mathrm{N} . \\
\text { minus } \\
\text { Clarion- } \\
\text { Clipperton } \\
\text { zone }\end{array}$ & $\begin{array}{c}0^{\circ}-<20^{\circ} \\
\mathrm{S} .\end{array}$ & $\begin{array}{c}20^{\circ}-<40^{\circ} \\
\mathrm{S} .\end{array}$ & $\begin{array}{c}40^{\circ}-<60^{\circ} \\
\mathrm{S} .\end{array}$ & $\geq 60^{\circ} \mathrm{S}$. \\
\hline Mn _ _ & $15.67(33.9)$ & $18.10(40.9)$ & $22.10(50.3)$ & $20.41(50.3)$ & $18.20(42.3)$ & $15.20(38.0)$ & $13.40(36.0)$ & 9.40 \\
\hline $\mathrm{Fe}$ & $15.46(26.0)$ & $13.64(50.0)$ & $9.20(26.7)$ & $11.17(26.7)$ & $13.80(34.0)$ & $15.90(39.6)$ & $14.60(30.6)$ & $14.90(25.6)$ \\
\hline $\mathrm{Ni}$ & $.31(.72)$ & $.57(1.69)$ & $.93(1.95)$ & $.72(1.60)$ & $.55(1.80)$ & $.42(1.73)$ & $.45(1.65)$ & $.31(1.00)$ \\
\hline $\mathrm{Cu}$ & $.14(.49)$ & $.32(1.10)$ & $.73(1.90)$ & $.55(1.90)$ & $.37(1.66)$ & $.20(.88)$ & $.20(.89)$ & $.19(.58)$ \\
\hline $\mathrm{Ni}+\mathrm{Cu}_{2}$ & $.45(1.21)$ & $.89(2.46)$ & $1.67(3.44)$ & $1.27(3.44)$ & $.91(3.24)$ & $.61(2.30)$ & $.65(2.49)$ & $.49(1.58)$ \\
\hline Co & $.32(1.01)$ & $.28(1.64)$ & $.26(1.50)$ & $.28(1.50)$ & $.29(1.88)$ & $.29(2.23)$ & $.19(1.06)$ & $.19(.57)$ \\
\hline Total & 31.90 & 32.91 & 33.22 & 33.13 & 33.21 & 32.01 & 28.84 & 24.99 \\
\hline
\end{tabular}

\footnotetext{
${ }^{1}$ In northeastern equatorial Pacific. The Clarion-Clipperton zone as a whole is taken to be the area defined by $7^{\circ}$ to $15^{\circ} \mathrm{N}$., $114^{\circ}$ to $153^{\circ} \mathrm{W}$.
} 


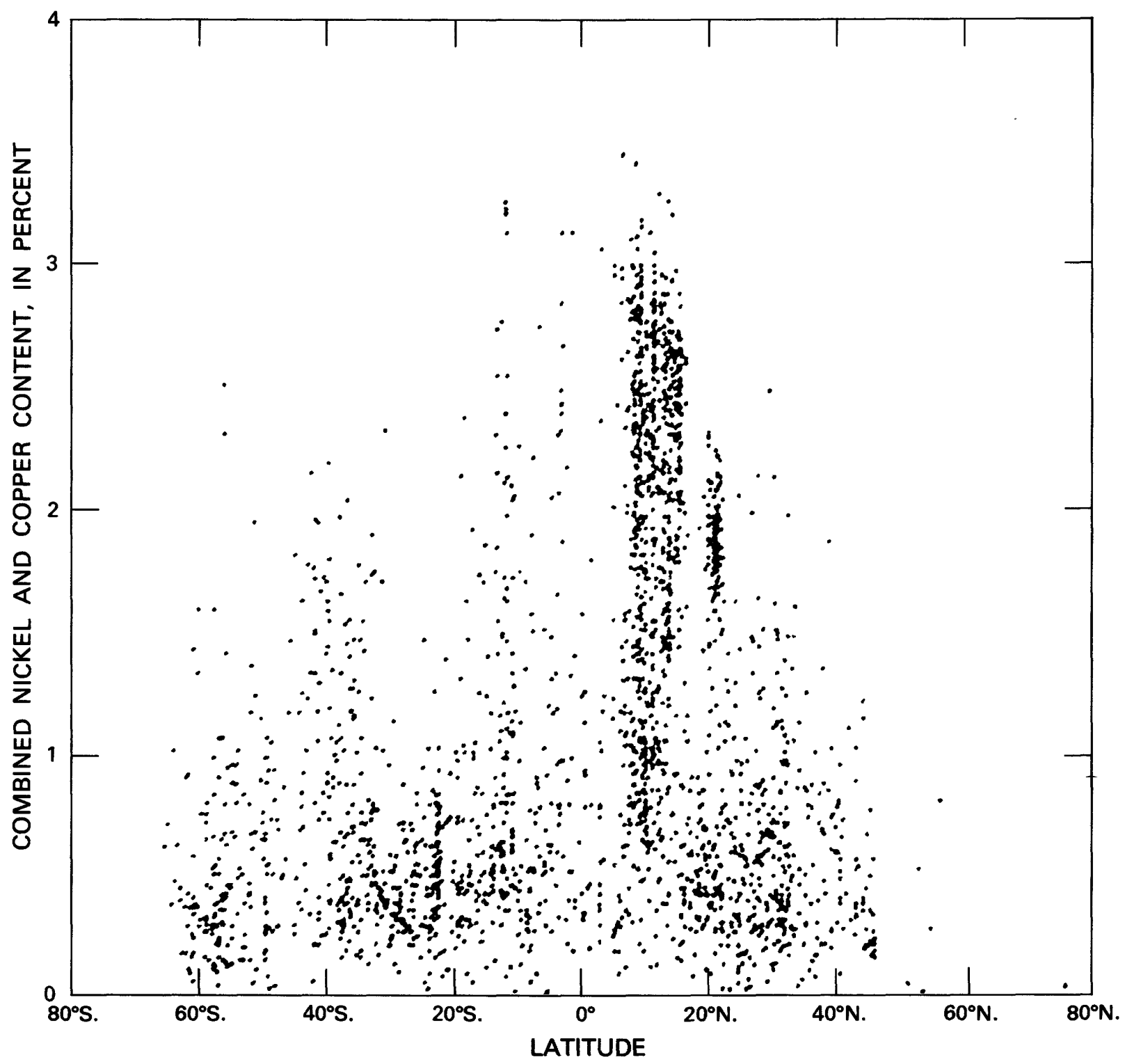

FiguRE 3.-Relation between combined nickel and copper content in manganese nodules and their latitudes at stations in the Scripps Institution of Oceanography's Sediment Data Bank.

Cronan, 1967, 1977, 1980; Cronan and Tooms, 1969; Piper, 1972, 1974; Horn and others, 1973; Skornyakova, 1976, 1979; Piper and Williamson, 1977; Pautot and others, 1978; J. Z. Frazer, written commun., 1980; Andrews and others, 1980). High values of cobalt, for example, are found mainly on seamounts, and cobalt content tends to decrease with increasing depth. Tables $1,3,6$, and 7 show a moderate negative correlation of cobalt with depth (south of latitude $60^{\circ} \mathrm{S}$., the correlation is weakly positive; the negative correlation is rather strong only in the group of samples from $40^{\circ}$ to $60^{\circ} \mathrm{N}$.) and a weak positive correlation of combined nickel and copper with depth. Data on three groups of stations are summarized in table 12. Stations in water depths of less than $2,000 \mathrm{~m}$ average 0.53 percent cobalt, 18.00 percent manganese, 14.81 percent iron, and only 0.50 percent combined nickel and copper. Samples from water depths of greater than 4,000 m average 18.6 percent manganese, 11.7 percent iron, 1.24 percent combined nickel and copper, and only 0.24 percent Co. If Clarion-Clipperton zone samples are eliminated, the average manganese value drops to 


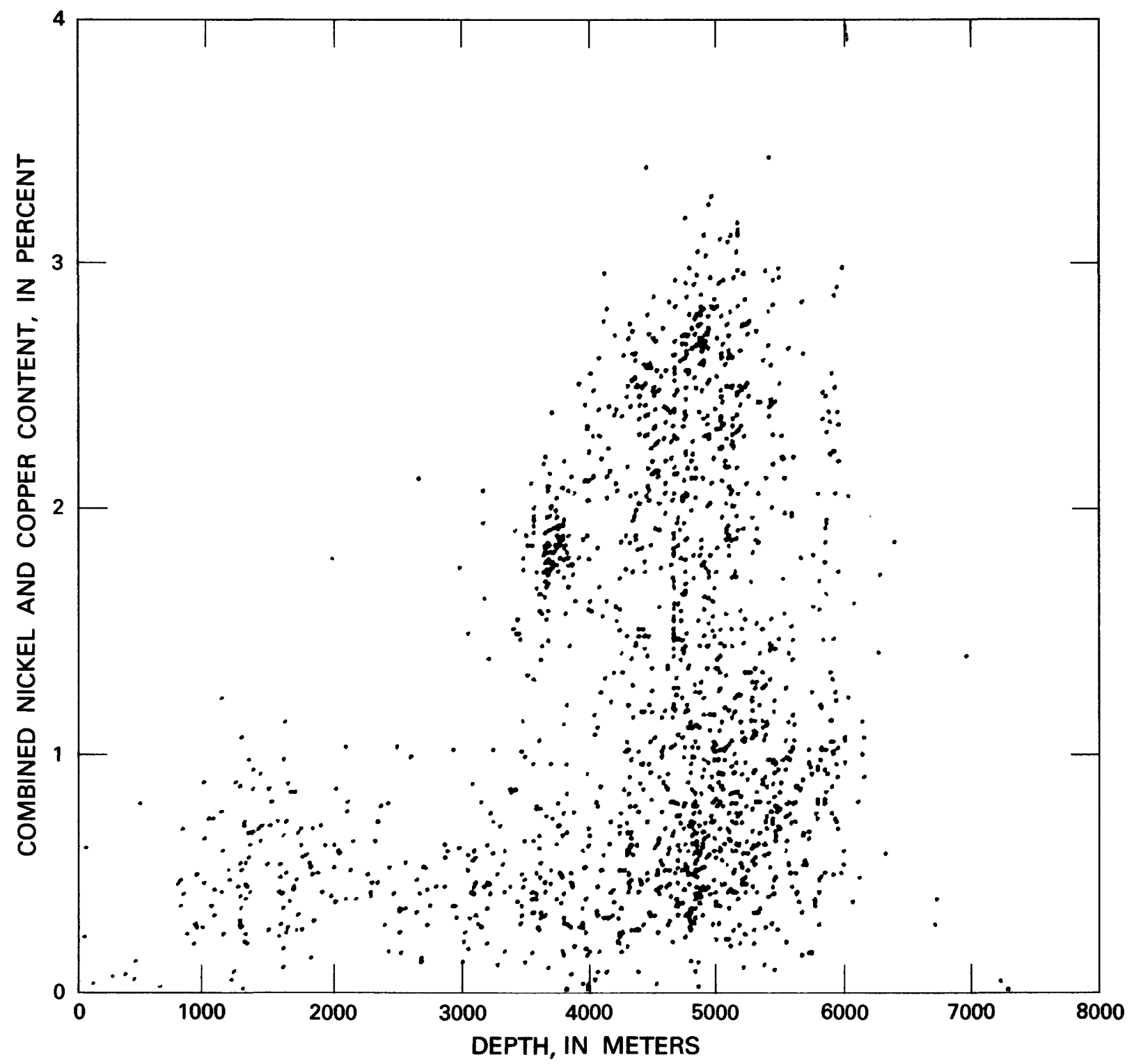

FIGURE 4. - Relation between depth and combined nickel and copper content in manganese nodules at stations in the Scripps Institution of Oceanography's Sediment Data Bank.

17.10 percent, combined nickel and copper decreases to 0.99 percent, iron increases to 13.01 percent, and cobalt content remains unchanged.

Given the rather marked differences in the metal contents of these groups, one might expect the correlations of nickel, copper, and cobalt with depth to be stronger than tables $1,3,6$, and 7 indicate. The explanation is found in figures 4 and 5 , which show that the depth relation is not linear; rather, there is a threshold depth of about 2,900 to $3,000 \mathrm{~m}$, above which combined nickel and copper contents greater than 1 percent are rare and below which nodules containing cobalt in amounts greater than about 0.6 percent are rare. As figures 6 through 11 show, below the threshold depth for combined nickel and copper and above it for cobalt, the maximum metal contents rise to an optimum depth range and then decline. Nodules containing more than 3.0 percent combined nickel and copper, for example, are found only in a depth range of about 4,450 to $5,450 \mathrm{~m}$ in the Pacific, and nearly all of them are in a range of 4,800 to $5,200 \mathrm{~m}$. No such values are found in the Atlantic, but the few samples containing more than 1.5 percent com- 


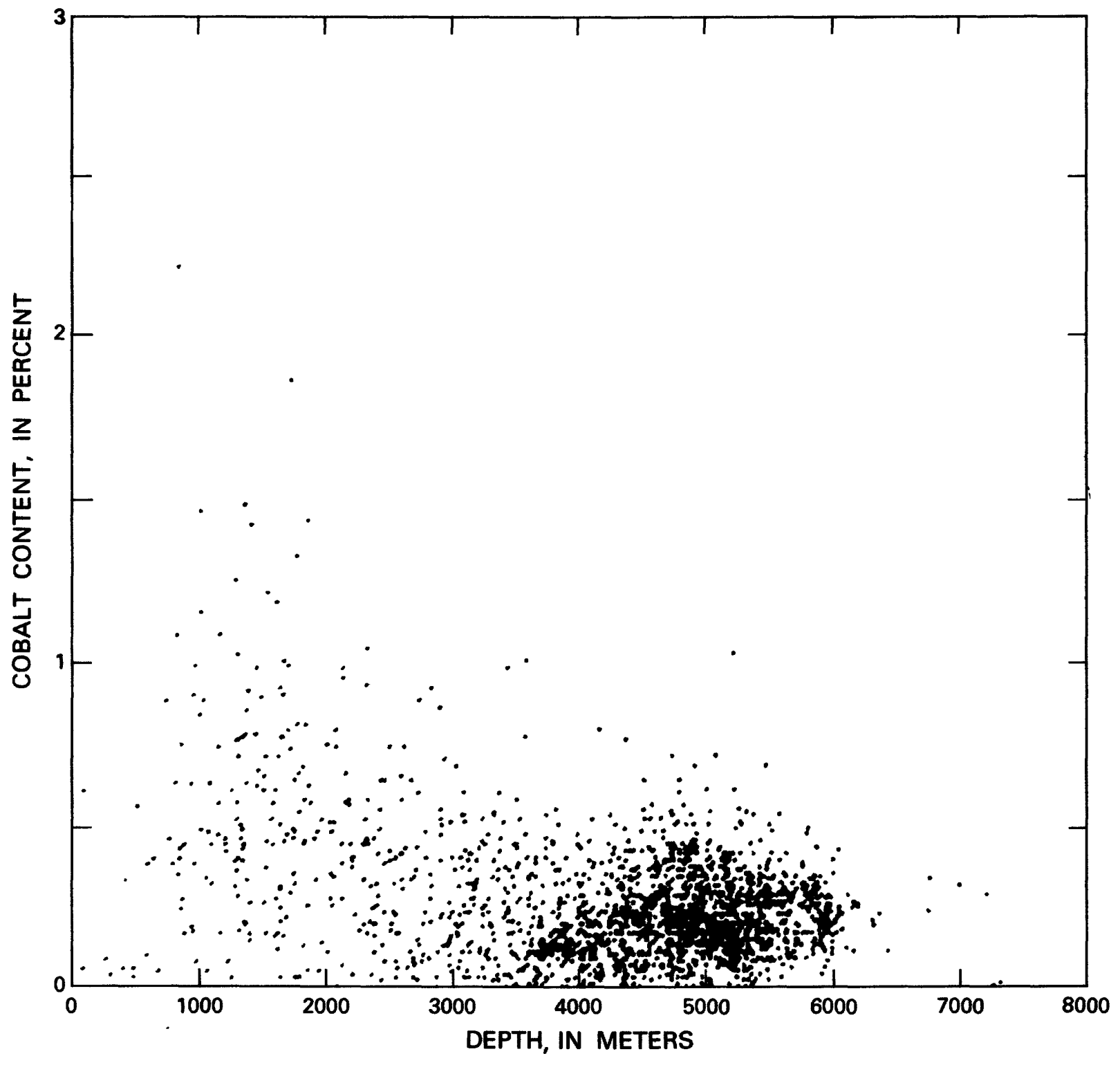

FiguRE 5. - Relation between depth and cobalt content in manganese nodules in the Scripps Institution of Oceanography's Sediment Data Bank.

TABLE 9.-Average and maximum (in parentheses) metal contents (in percent) of manganese nodules in the Pacific Ocean, categorized by latitude

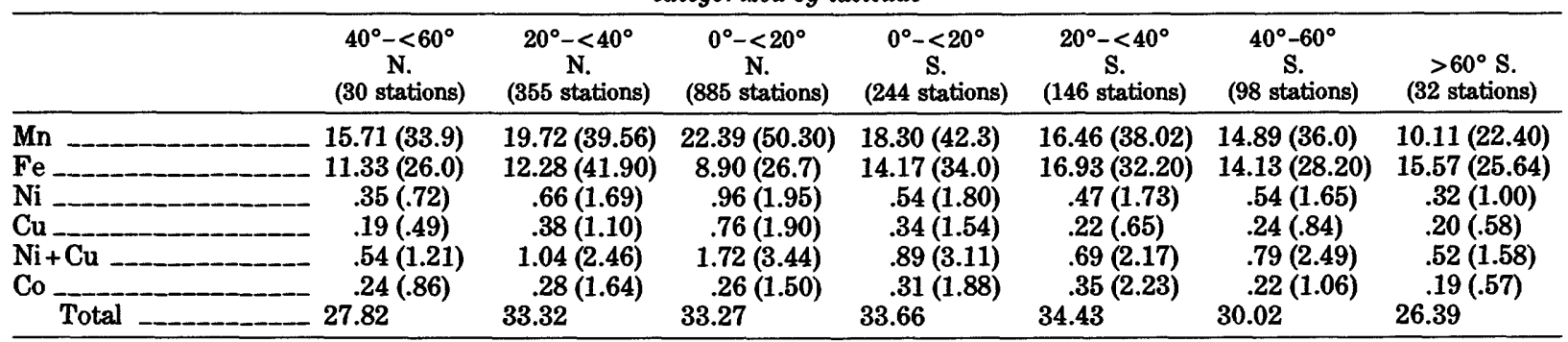




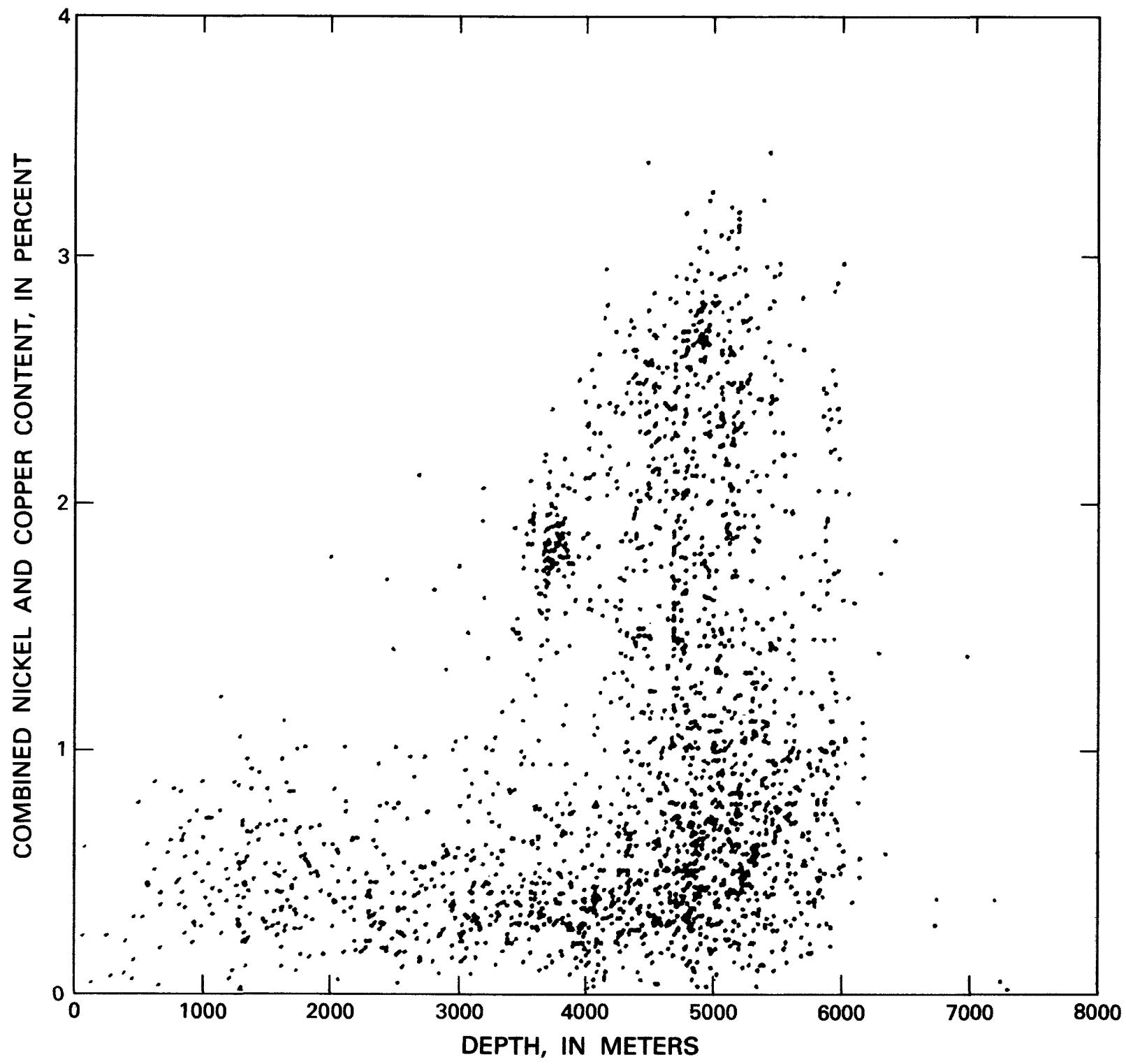

FiguRE 6. - Relation between depth and combined nickel and copper content in Pacific Ocean manganese nodules at 1,770 stations in the Scripps Institution of Oceanography's Sediment Data Bank.

TABLE 10.-Average and maximum (in parentheses) metal contents (in percent) of manganese nodules in the Atlantic Ocean, categorized by latitude

\begin{tabular}{|c|c|c|c|c|c|c|c|c|}
\hline & $\begin{array}{l}>60^{\circ} \mathrm{N} \\
(1 \text { station) }\end{array}$ & $\begin{array}{c}40^{\circ}-<60^{\circ} \mathrm{N} \\
\text { (30 stations) }\end{array}$ & $\begin{array}{l}20^{\circ}-<40^{\circ} \mathrm{N} \\
(120 \text { stations) }\end{array}$ & $\begin{array}{l}0^{\circ}-<20^{\circ} \mathrm{N} . \\
\text { (12 stations) }\end{array}$ & $\begin{array}{l}0^{\circ}-<20^{\circ} \mathrm{S} \text {. } \\
\text { (7 stations) }\end{array}$ & $\begin{array}{c}20^{\circ}-<40^{\circ} \mathrm{S} \text {. } \\
\text { (56 stations) }\end{array}$ & $\begin{array}{l}40^{\circ}-<60^{\circ} \mathrm{S} . \\
\text { (72 stations) }\end{array}$ & $\begin{array}{c}>60^{\circ} \mathrm{S} . \\
\text { (1 station) }\end{array}$ \\
\hline Mn & 10.36 & $15.03(27.39)$ & $13.25(40.90)$ & $14.06(34.80)$ & $15.13(24.00)$ & $14.51(26.78)$ & $11.16(26.64)$ & 1.00 \\
\hline $\mathrm{Fe}$ & 22.83 & $19.58(24.28)$ & $17.62(50.00)$ & $15.84(23.70)$ & $19.54(22.4)$ & $14.67(26.40)$ & $16.56(34.55)$ & 7.10 \\
\hline $\mathrm{Cu}$ & .03 & $.08(.34)$ & $.13(.62)$ & $.11(.48)$ & $.09(.15)$ & $.15(.88)$ & $.13(.41)$ & .10 \\
\hline $\mathrm{Ni}+\mathrm{Cu}$ & .04 & $.35(1.02)$ & $.44(1.97)$ & $.35(1.21)$ & $.34(.51)$ & $.57(2.30)$ & $.43(1.40)$ & .24 \\
\hline $\mathrm{Co}$ & .18 & $.39(1.01)$ & $.29(1.04)$ & $.25(0.51)$ & $.49(1.44)$ & $.30(1.01)$ & $.16(.76)$ & .10 \\
\hline
\end{tabular}




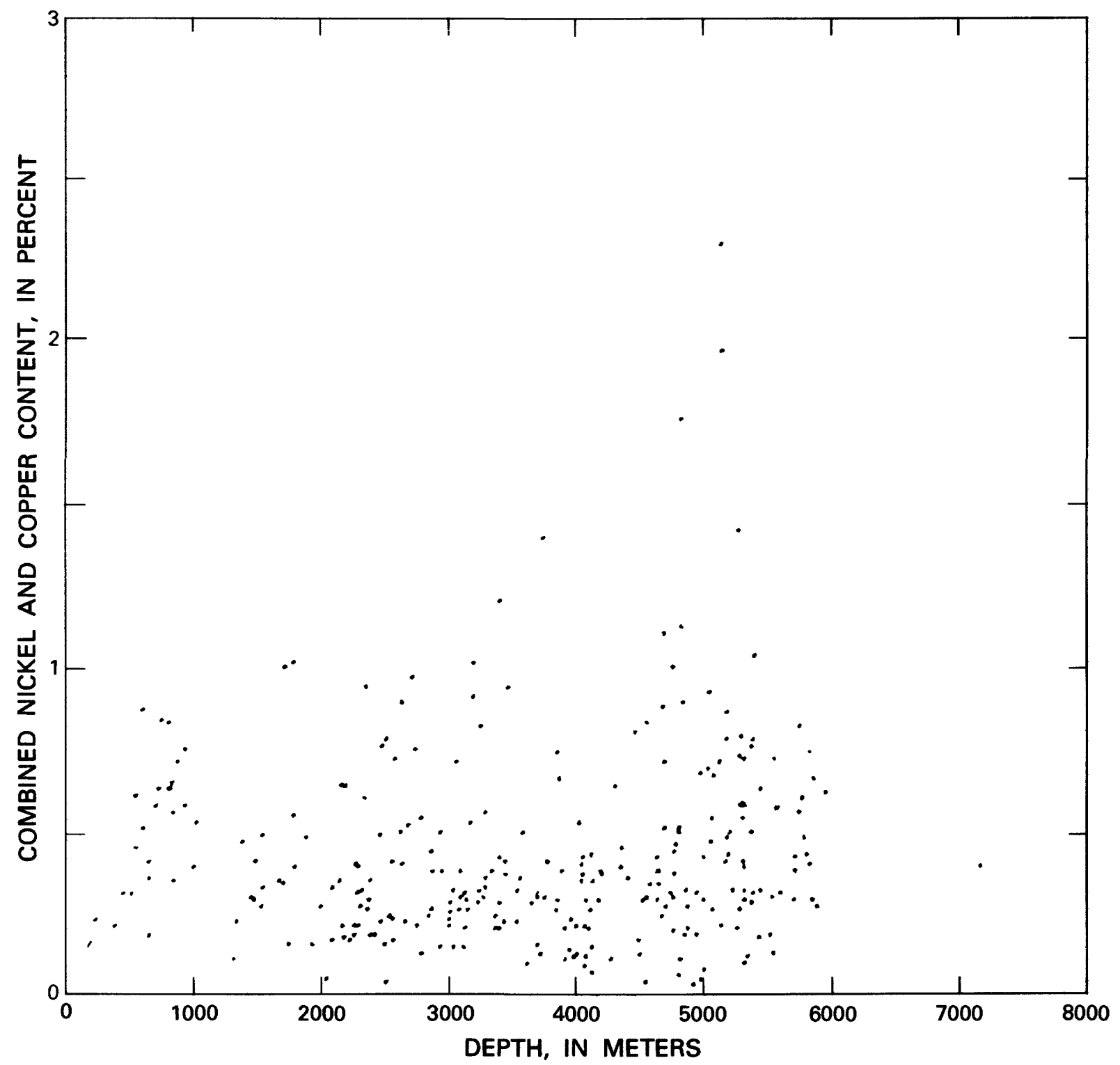

Figure 7.-Relation between depth and combined nickel and copper content in Atlantic Ocean manganese nodules at 296 stations in the Scripps Institution of Oceanography's Sediment Data Bank.

TABLE 11. -Average and maximum (in parentheses) metal contents (in percent) of manganese nodules in the Indian Ocean, categorized by latitude

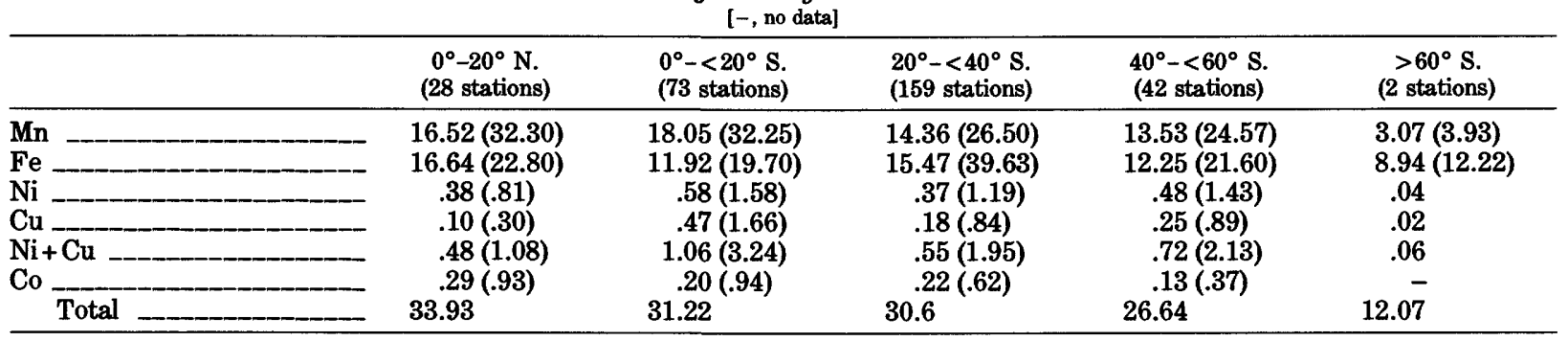




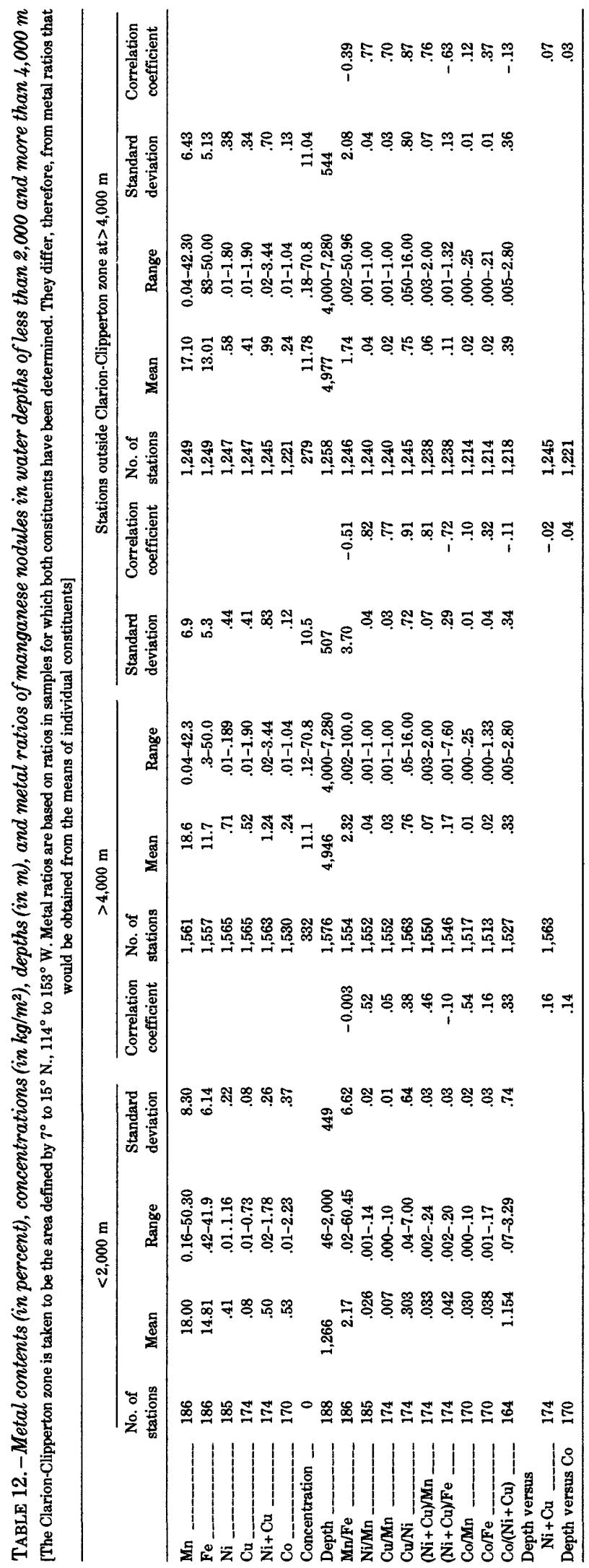




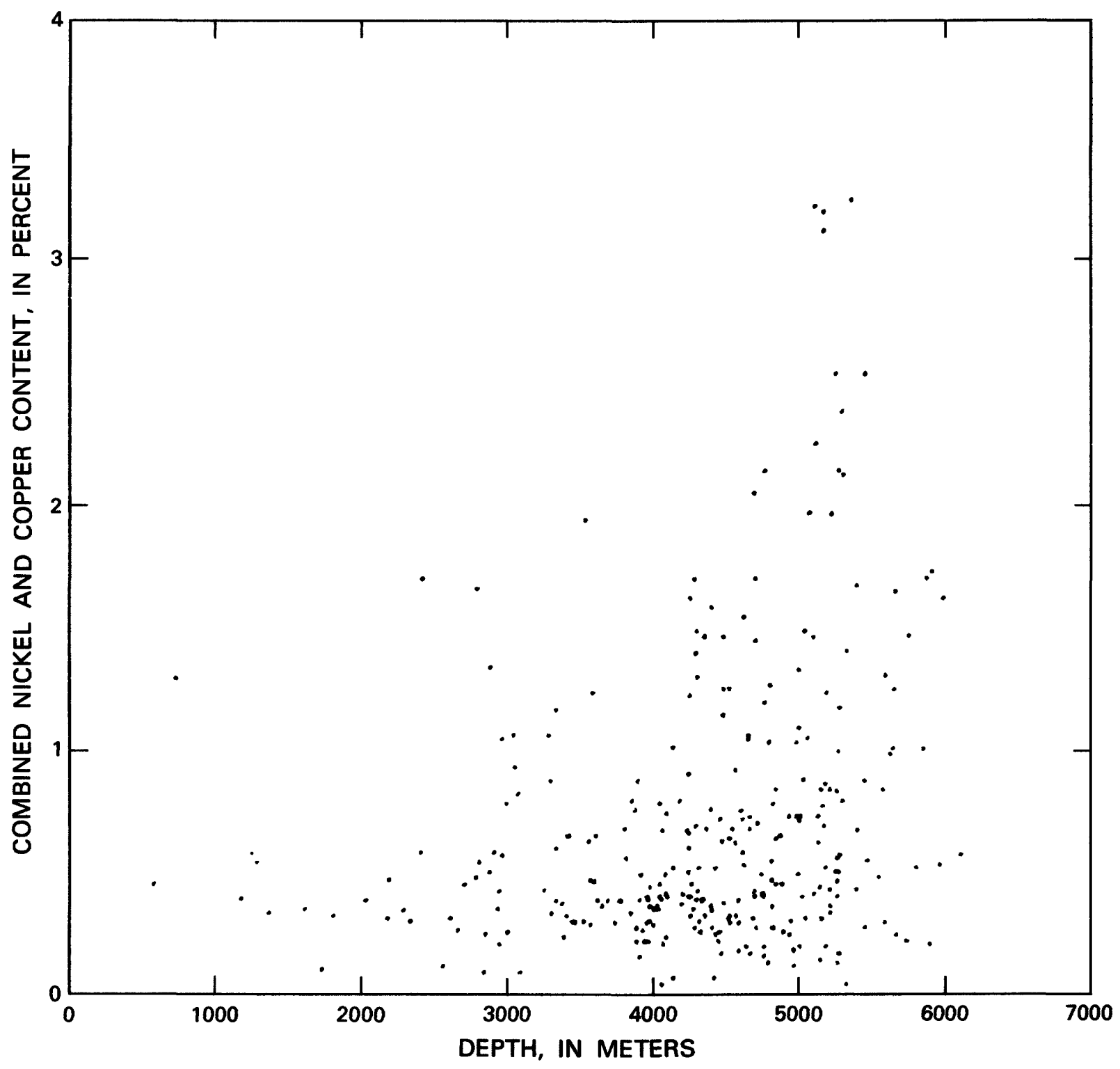

FiguRE 8. - Relation between depth and combined nickel and copper content in Indian Ocean manganese nodules at 300 stations in the Scripps Institution of Oceanography's Sediment Data Bank.

bined nickel and copper occur in a depth range of about 4,850 to 5,200 m. In the Pacific, the optimum depth range for nodules containing more than 1 percent cobalt is about 800 to $1,850 \mathrm{~m}$; in the Atlantic, it is about 1,000 to $1,650 \mathrm{~m}$. No such high values have been found in Indian nodules, but one of the two highest reported is from a depth of about $1,350 \mathrm{~m}$. The rather substantial differences in the mean values of nickel, copper, iron, and cobalt above and below the 3000-m depth are shown in table 13.
Cronan and Tooms (1969, p. 340) also noted the enrichment of nickel and copper in the deeper water nodules and observed "that $3000-4000 \mathrm{~m}$ is a critical depth for many of the elements. In the case of $\mathrm{Co}, \mathrm{Cu}, \mathrm{Pb}, \mathrm{Ba}$, and $\mathrm{V}$, in particular, there is a sharp difference between the concentrations above and below $3000 \mathrm{~m}$. Those elements which are in higher concentrations in the shallower waters tend to increase gradually in concentration from $3000 \mathrm{~m}$ to the surface. A similar distribution is observed in the case of $\mathrm{Cu}$ although the highest average con- 


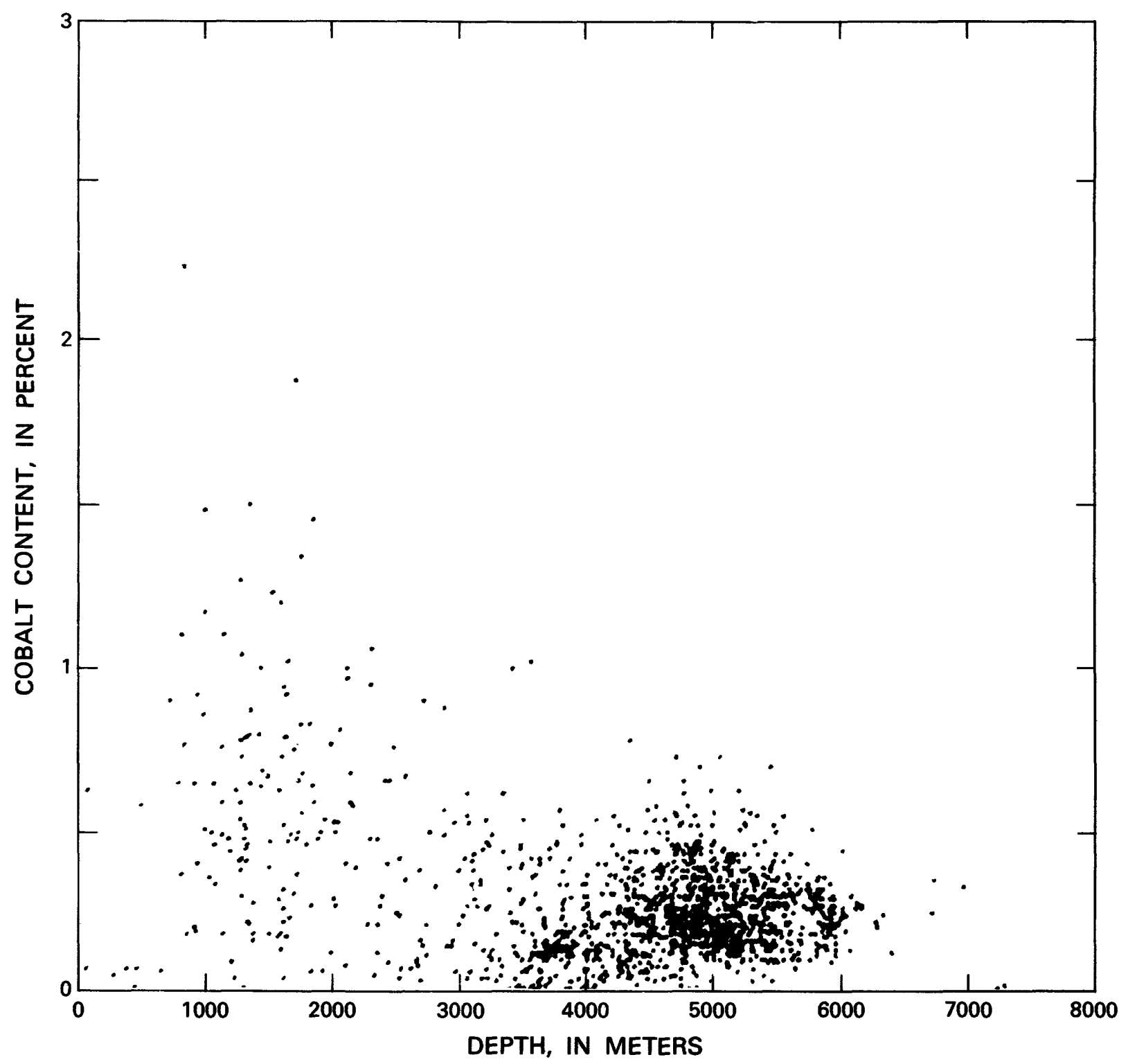

Figure 9.-Relation between depth and cobalt content in Pacific Ocean manganese nodules at 1,710 stations in the Scripps Institution of Oceanography's Sediment Data Bank.

TABLE 13. - Metal contents of manganese nodules in water depths above and below $3,000 \mathrm{~m}$

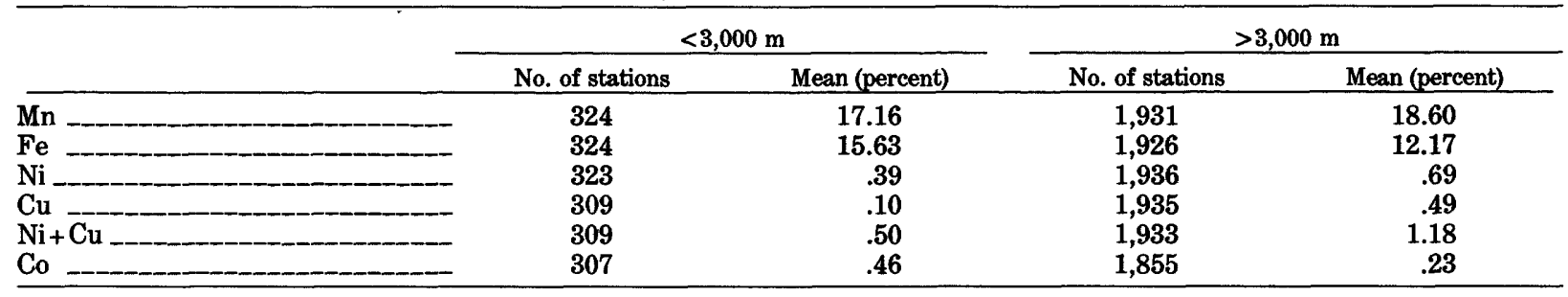




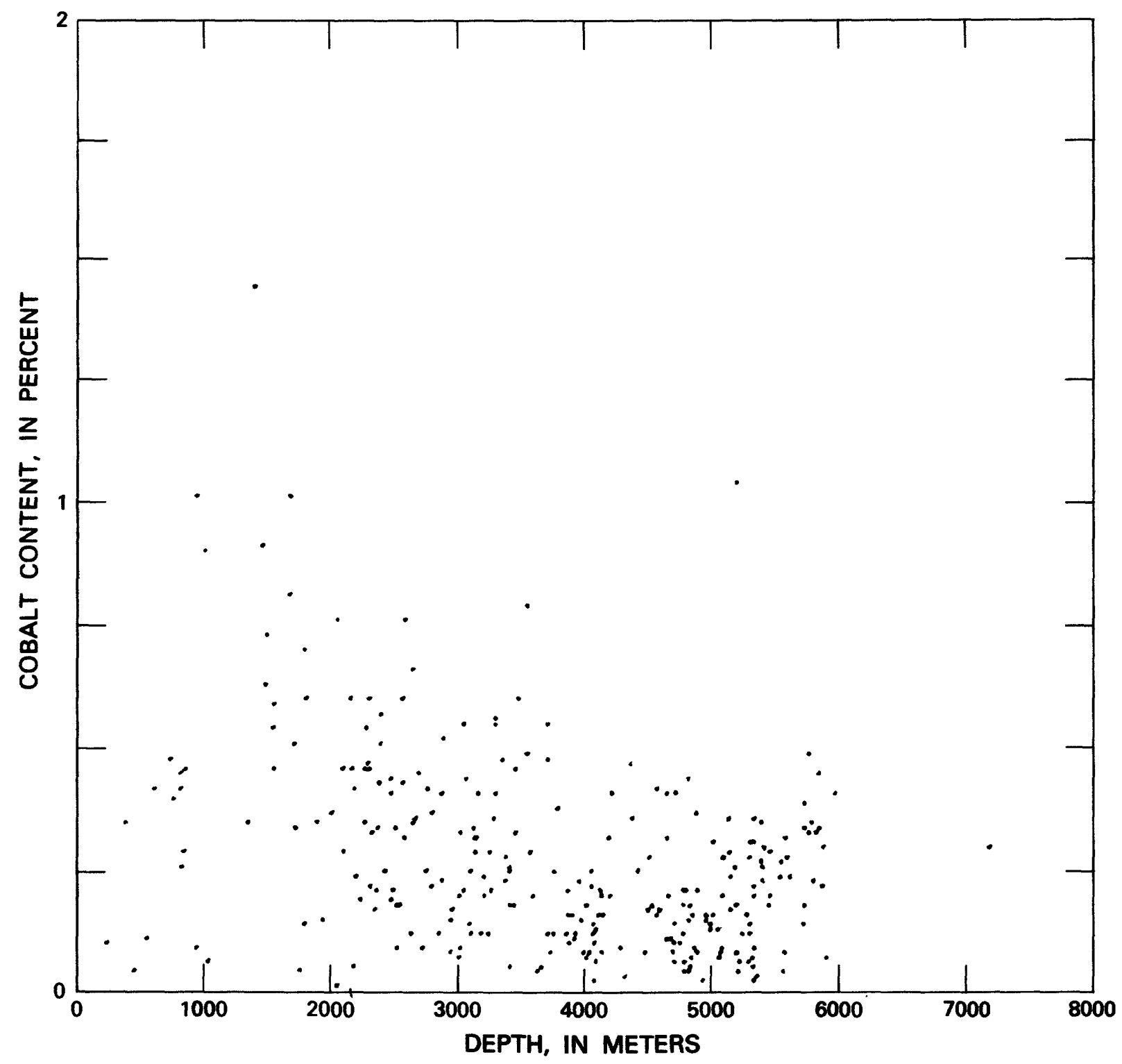

FIGURE 10. - Relation between depth and cobalt content in Atlantic Ocean manganese nodules at 285 stations in the Scripps Institution of Oceanography's Sediment Data Bank.

centrations are recorded at the maximum depths." (As indicated above, the increase "to the surface" does not hold for cobalt). Piper (1974) reported that the rare-earth composition of nodules also changes at the 3,000-m depth, and Piper and Williamson (1977) showed that the high values of the manganese-iron ratio as well as those of nickel and copper are below this depth.

As figure 12 shows, manganese shows little correlation with depth, although the data suggest a decrease in the maximum values and possibly an increase in the minimum with increasing depth. No nodule analysis shows more than 32 percent manganese below depths of $5,300 \mathrm{~m}$, and only one reports less than about 13 percent below $6,000 \mathrm{~m}$.

The increase in the copper-nickel ratio with increasing depth reported by S. A. Mooreby (unpublished thesis, 1978, discussed by Cronan (1980)) for Indian Ocean nodules is seen also by comparing the mean copper-nickel ratio with mean depths in the various populations analyzed in the tables here. Thus, at the mean depth of $1,266 \mathrm{~m}$ for samples from depths of less than $2,000 \mathrm{~m}$, the copper-nickel ratio is 0.196 ; at a mean depth of $3,395 \mathrm{~m}$ for 


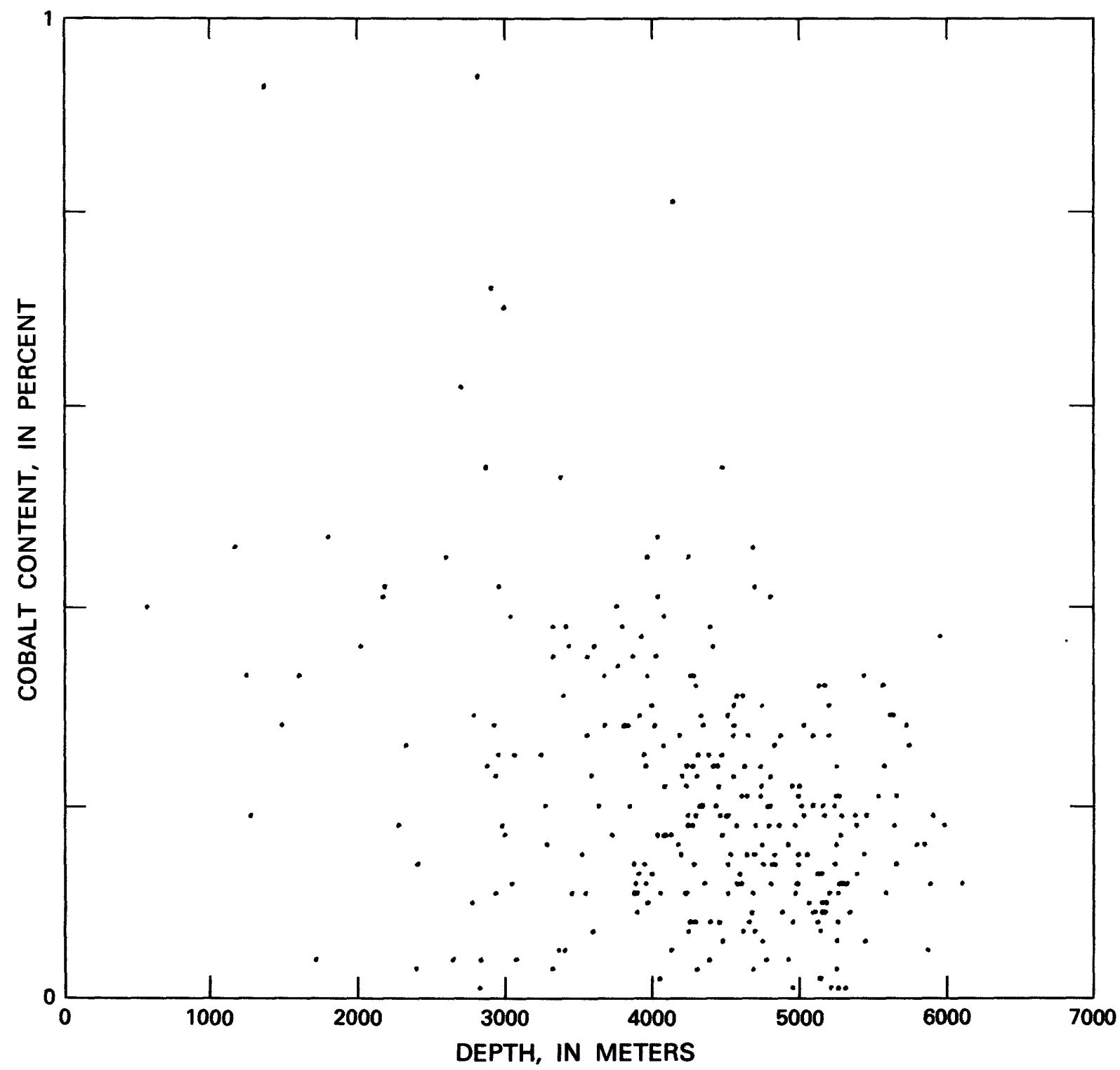

FIGURE 11.-Relation between depth and cobalt content in Indian Ocean manganese nodules at 289 stations in the Scripps Institution of Oceanography's Sediment Data Bank.

samples between $40^{\circ}$ and $60^{\circ} \mathrm{N}$, the ratio is 0.49 ; at a mean depth of $4,379 \mathrm{~m}$ for all Pacific stations, it is 0.71 .

\section{RELATION OF NODULE CONCENTRATION TO WATER DEPTH}

The publicly available data on concentration of manganese nodules are insufficient, especially outside of the Pacific, to support any firm conclusions, but, in the population shown in figure 13, all but one of the stations having more than about $13 \mathrm{~kg}$ of nodules per square meter occur at depths greater than about 3,700 m. Analysis of hundreds of freefall grab samples collected by the Centre National pour l'Exploitation des Oceans-Société Le Nickel and the Association Française pour l'Etude et la Recherche des Nodules Polymetalliques led Pautot and Melguen (1979) to conclude that the greatest concentrations of nodules are restricted to an interval of 300 to $400 \mathrm{~m}$, the lower limit of which varies from basin to basin but falls within the range of 4,350 to $5,200 \mathrm{~m}$-close to the carbonate 


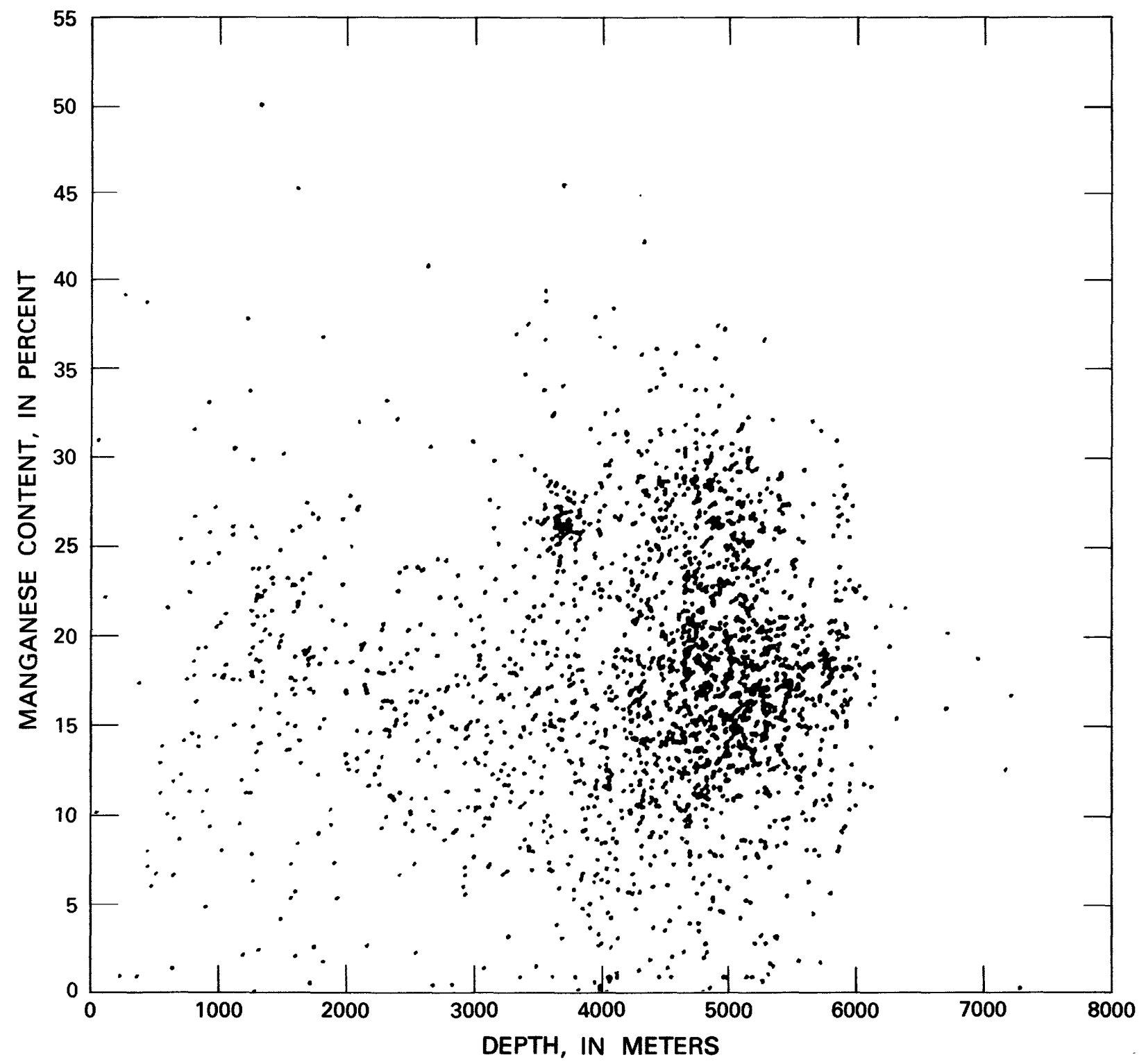

FIGURE 12.-Relation between depth and manganese content in manganese nodules at stations in the Scripps Institution of Oceanography's Sediment Data Bank.

compensation depth in each basin. Skornyakova (1979) also reported that the highest concentrations are confined to depths below the carbonate concentration depth.

Although available evidence thus indicates that the greatest concentrations of nodules occur at abyssal depths, the encrustations, which average 2 $\mathrm{cm}$ in thickness over large areas, reported by Manheim and others (1982) on mid-Pacific seamounts at depths between 2,500 and 1,200 m represent a far greater concentration of metalliferous oxides per unit area than the nodules do, except in their rarest concentrations; in fact, the average concentration of manganese oxide crust of $33 \mathrm{~kg} / \mathrm{m}^{2}$ implied by Manheim and Halbach is four times the average of $8.33 \mathrm{~kg} / \mathrm{m}^{2} \mathrm{dry}$ weight in nodules of the Clarion-Clipperton zone.

\section{METAL-RICH TYPES OF MANGANESE NODULES}

Examination of metal-rich manganese nodules led us to conclude that three distinct, only rarely overlapping compositional types of possible 


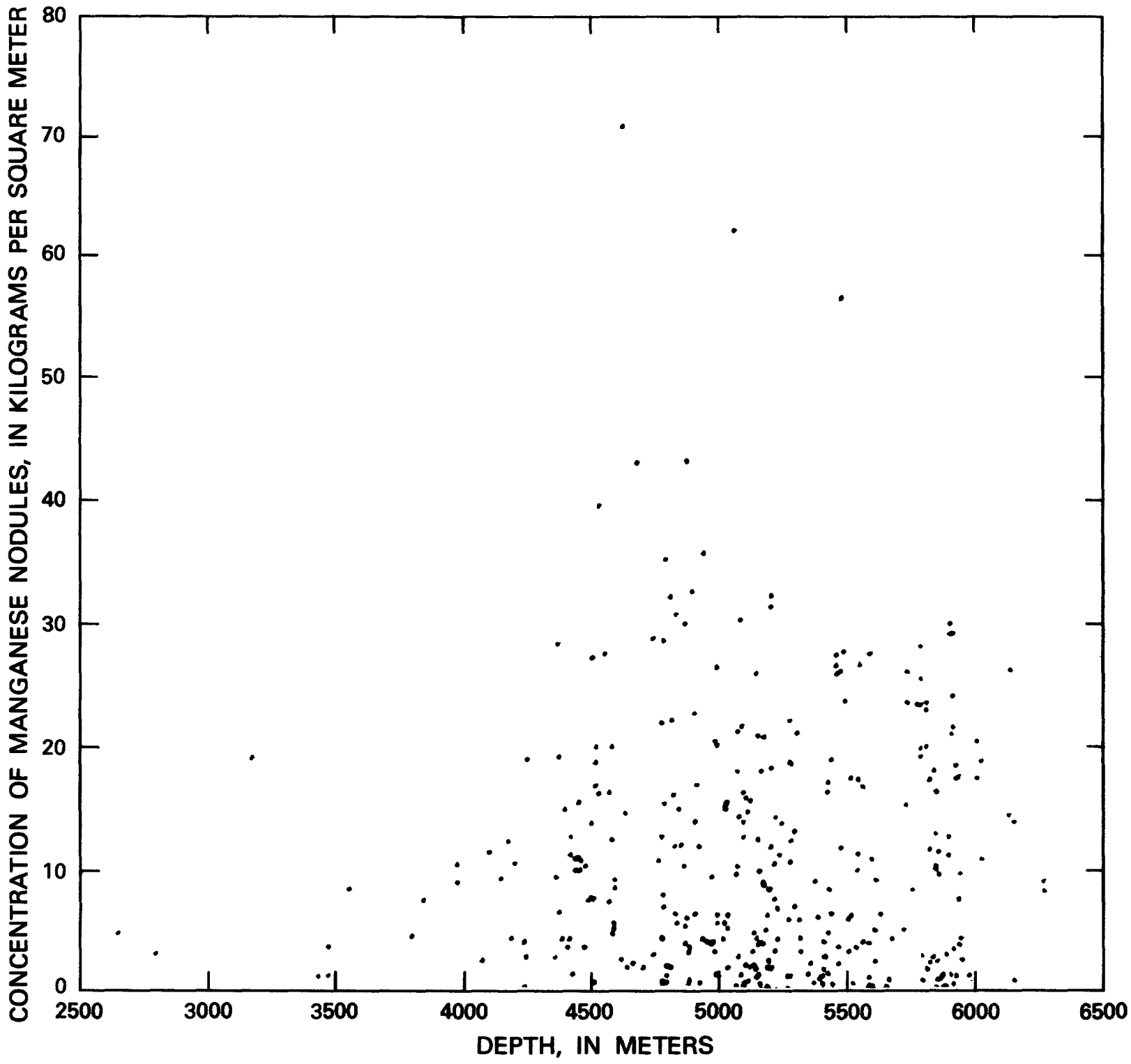

Figure 13.-Relation between depth and concentration of manganese nodules at stations in the Scripps Institution of Oceanography's Sediment Data Bank.

economic interest could be recognized: (1) nodules containing more than 1 percent combined nickel and copper, (2) nodules containing more than 0.5 percent cobalt, and (3) nodules containing more than 35 percent manganese (although nodules in this group contain more than 0.5 percent cobalt only exceptionally, they do average nearly 1.1 percent combined nickel and copper). The metal contents of these types are summarized in tables 14 , 15, and 16; the groups having high combined nickel and copper contents and high cobalt contents have been broken into two parts. These groups are similar to ones defined for the composition of Pacific nodules by Howarth and others (1977) by means of a nonlinear mapping technique. Their group 2, for example, averages 0.60 percent cobalt, 0.56 percent combined nickel and copper, and 15.58 percent manganese. Their groups 3, 4, and 5 average $0.3,0.27$, and 0.17 percent cobalt, $1.15,1.97$, and 2.74 percent combined nickel and copper, and 17.67, 22.07, and 26.99 percent manganese, respectively. Their group 6 averages 0.06 percent copper, 1.05 combined nickel and copper, and 34.29 percent manganese. 


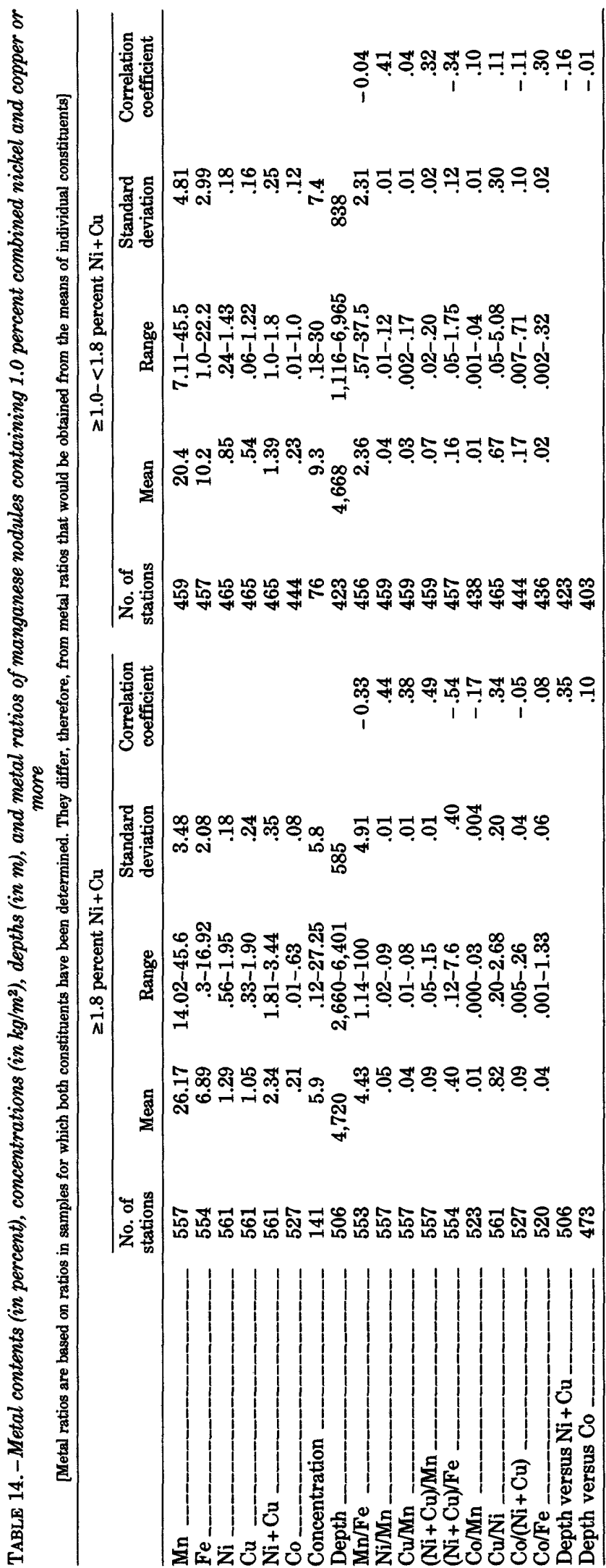




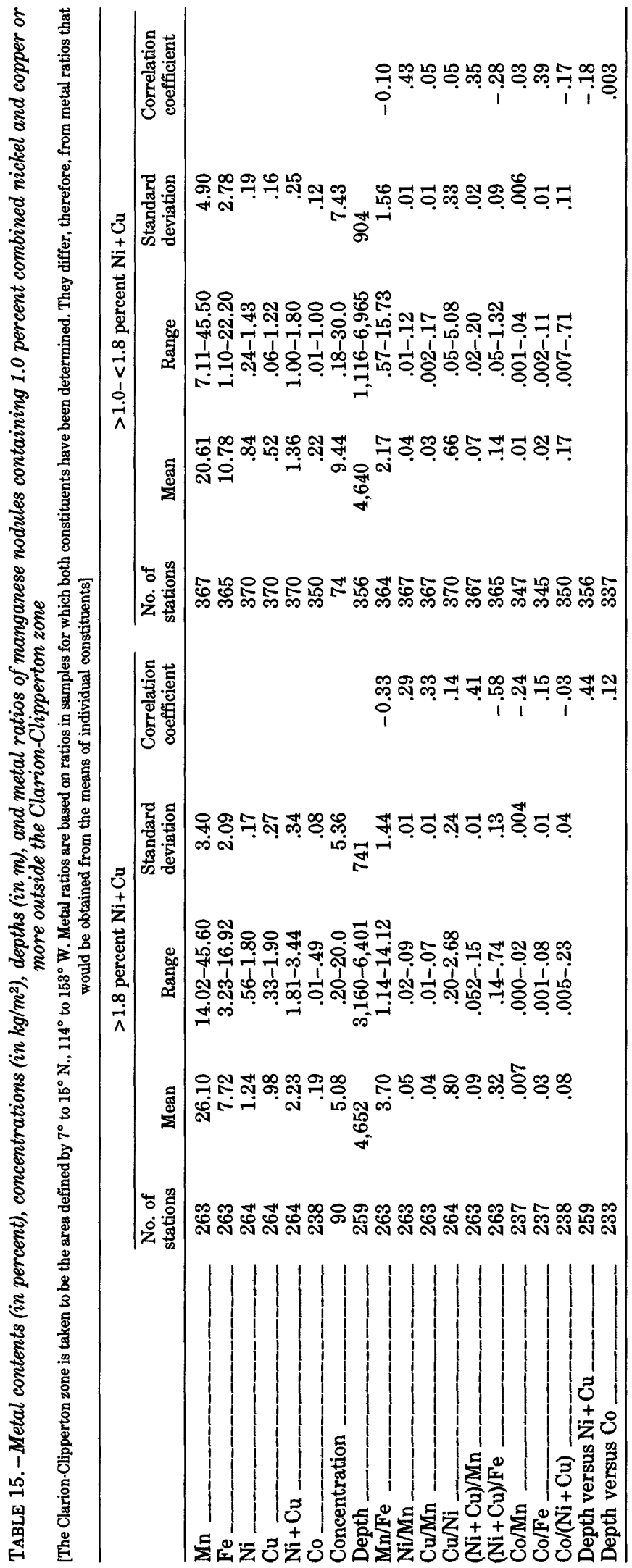




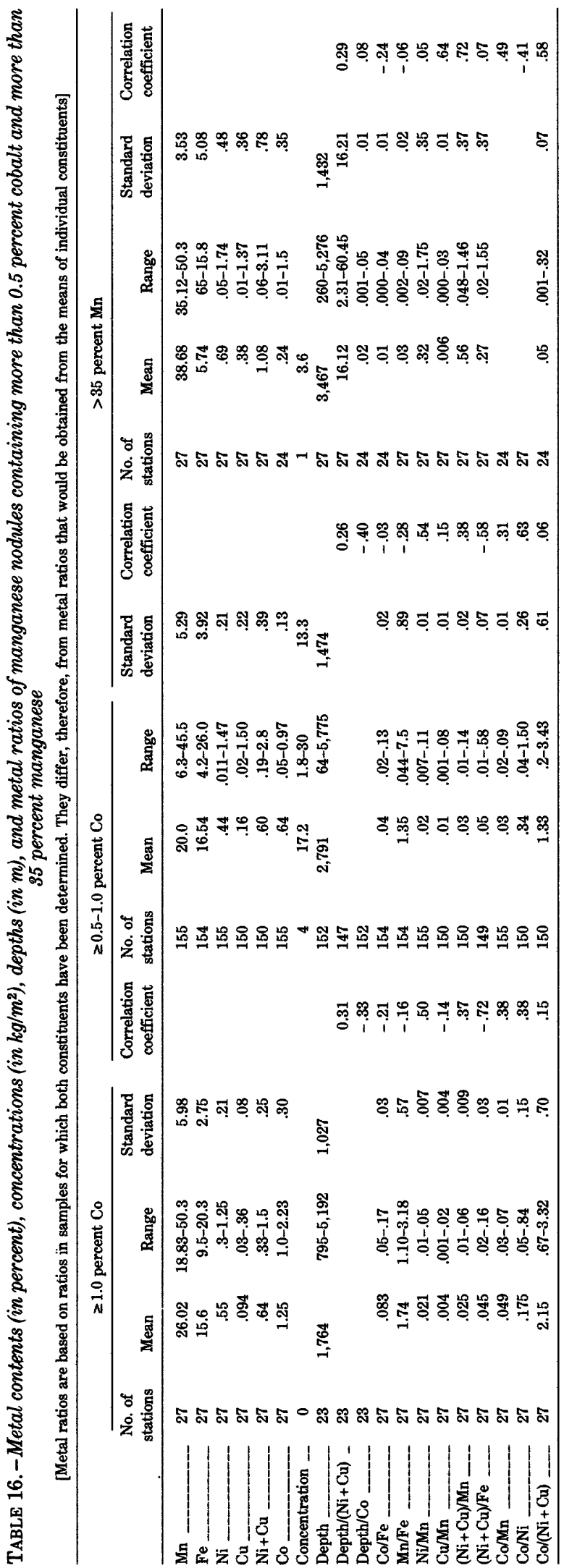


Tables 14 and 15 show nodules high in combined nickel and copper worldwide and outside the Clarion-Clipperton zone. Average combined nickel and copper contents of nodules within the ClarionClipperton zone seem to be slightly richer than those of nodules outside, but nodules rich in combined nickel and copper have essentially the same chemical compositions wherever they are found. Given the depth and latitude relations already discussed, one would expect nodules rich in nickel and copper to occur at abyssal depths in low latitudes; tables 14 and 15 and figures 14 and 15 confirm this expectation. Figures 14 and 15, however, show that nodules rich in nickel and copper also occur at higher latitudes. In both the Pacific and the Indian Oceans, nodules richest in nickel and copper are found mainly in the eastern parts (Cronan and Tooms, 1969; Tooms and others, 1969; Cronan, 1980). Nodules containing 1.8 percent combined nickel and copper or more are essentially absent from the Pacific west of $180^{\circ}$ W., even at low latitudes, and none have been reported west of $75^{\circ} \mathrm{E}$. in the Indian Ocean (fig. 14). Only a few samples containing 1.8 percent combined nickel and copper or more have been reported from the Atlantic, but the largest concentrations of samples containing $\geq 1.0$ to $<1.8$ percent also lie on the eastern side of the basin (fig. 15).

Nodules containing $\geq 1.0$ to $<1.8$ percent combined nickel and copper are generally distinct from those in the cobalt- and manganese-rich groups. In comparison with those containing 1.8 percent combined nickel and copper or more, they are lower in manganese and higher in iron, and their coppernickel ratio is appreciably lower.

Tables 14 and 15 indicate that the concentration of nodules on the sea floor is inversely related to combined nickel and copper content, both in the lower average concentration found in the $\geq 1$.8percent nodules in comparison with those in the $\geq 1.0$ - to $<1.8$-percent range and in the maximum nodule concentration in each group. This relation was previously reported by Menard and Frazer (1978) for the entire Pacific but was found to be weak in the Clarion-Clipperton zone (McKelvey and others, 1979).

The manganese content of nodules high in cobalt (table 16) is similar to that of nodules high in combined nickel and copper, but the iron content is much higher. They are low in combined nickel and copper, and the copper-nickel ratio is also low. Comparison of the $\geq 0.5$ - to $\leq 1.0$-percent group shows that manganese is appreciably higher in the $\geq 1$.0-percent group, iron is slightly lower, the copper-nickel ratio is lower, and the average depth is about $1,000 \mathrm{~m}$ less. Figures 16 and 17 suggest, along with previous observations (for example, Mero, 1962; Menard, 1964; Cronan and Tooms, 1969; Piper and Williamson, 1977; Calvert, 1978), that, although cobalt-rich nodules occur over a wide range of latitudes and longitudes, those containing more than 1 percent and even more than 0.5 percent cobalt are relatively more populous in the central and western Pacific. The $\geq 1.0$ percent cobalt group is essentially of the same composition as the encrustations recently reported on midPacific seamounts by Manheim and others (1982) $-1.0,0.5,25.0$, and $<0.1$ percent cobalt, nickel, manganese, and copper, respectively, in the crusts, according to Manheim and others, in comparison with $1.25,0.55,26.02$, and 0.094 percent averages for the same metals in the $\geq 1.0$ percent cobalt nodules shown in table 16 . It may be that some of the samples reported as nodules in the Scripps Data Bank are in fact encrustations.

Nodules containing more than 1.0 percent cobalt have not been reported in the Indian Ocean, but those containing 0.5 percent cobalt or more are confined to the western side of that basin. The number of samples in the $\geq 1.0$-percent cobalt group is only 27 , perhaps not enough to justify much confidence in the observations made about them here.

Nodules high in manganese (table 16) also have been found at only 27 stations, again too few to support much generalization about them. The data, however, indicate that they are relatively low in iron (some are very low); the mean manganese-iron ratio is 16.12 , in comparison with 4.43 for nodules of the 1.8-percent or more combined nickel and copper type. The average combined nickel and copper content, 1.08 percent, falls in the lower range of the $\geq 1.0$ - to $<1.8$-percent combined nickel and copper group. Halbach and Fellerer (1980) found, for nodules from the southeastern Pacific, that combined nickel and copper increases as the manganese-iron ratio increases up to about 5 and decreases as the ratio increases further.

Although the number of samples shown in figure 18 is small, all but two of them occur in the eastern and north equatorial Pacific (see also Mero, 1962; Cronan and Tooms, 1969; Skornyakova, 1979; Cronan, 1980; Heath, 1981). Only one sample is in the Atlantic, and none have been found in the Indian Ocean. Whereas the nodules especially rich in 


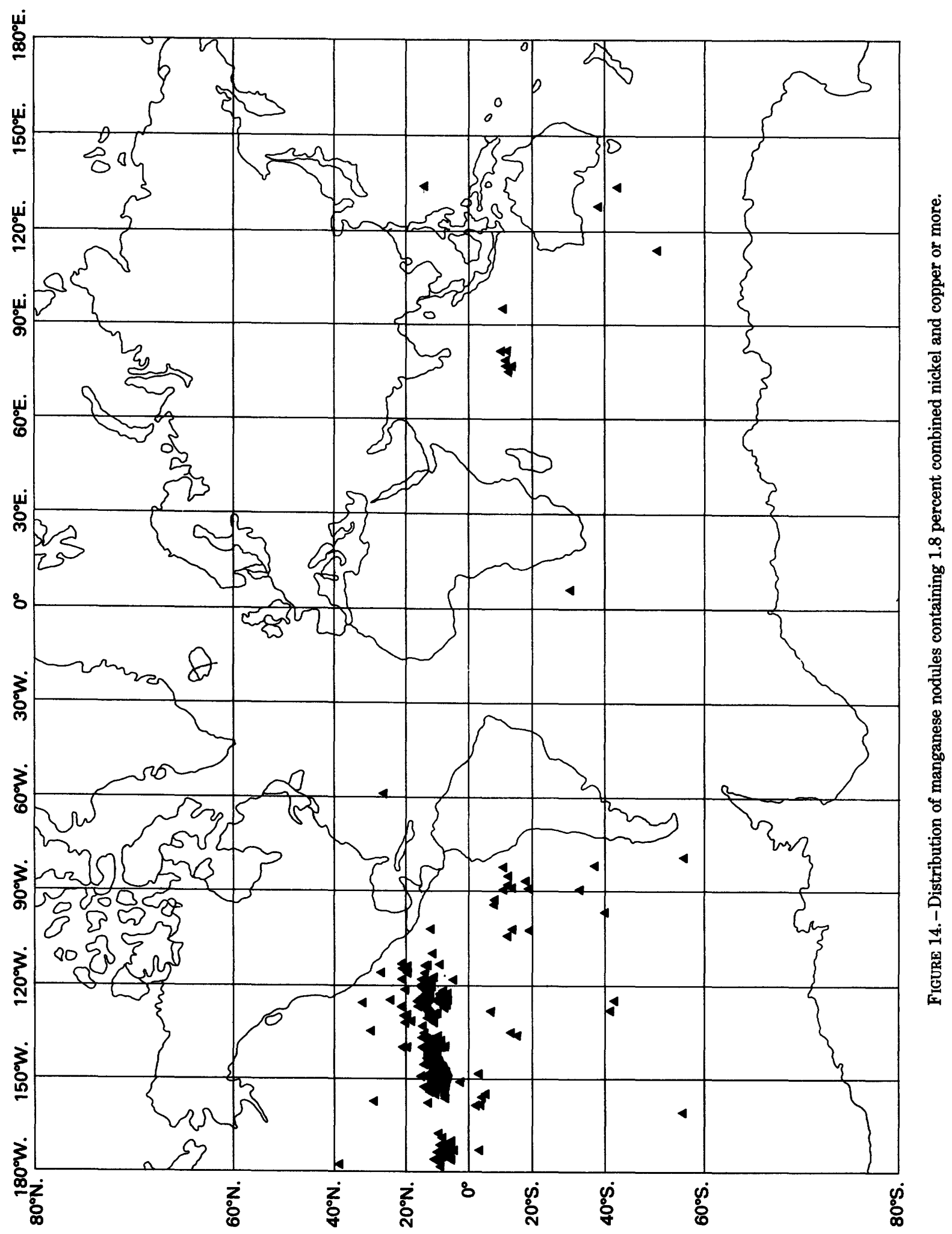




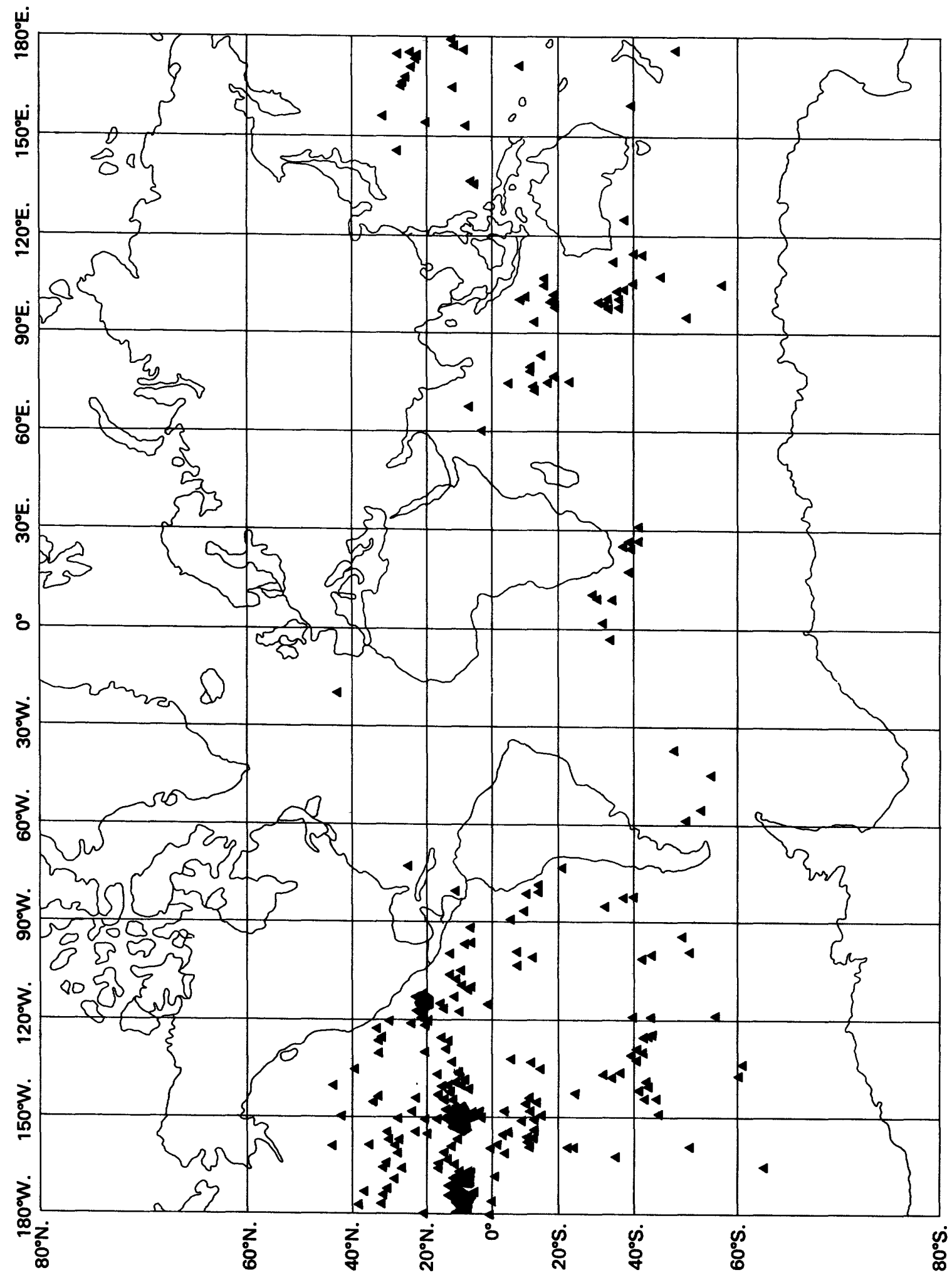

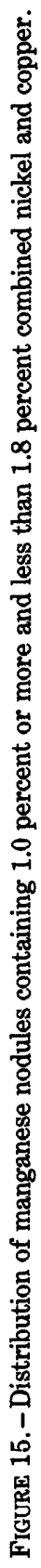




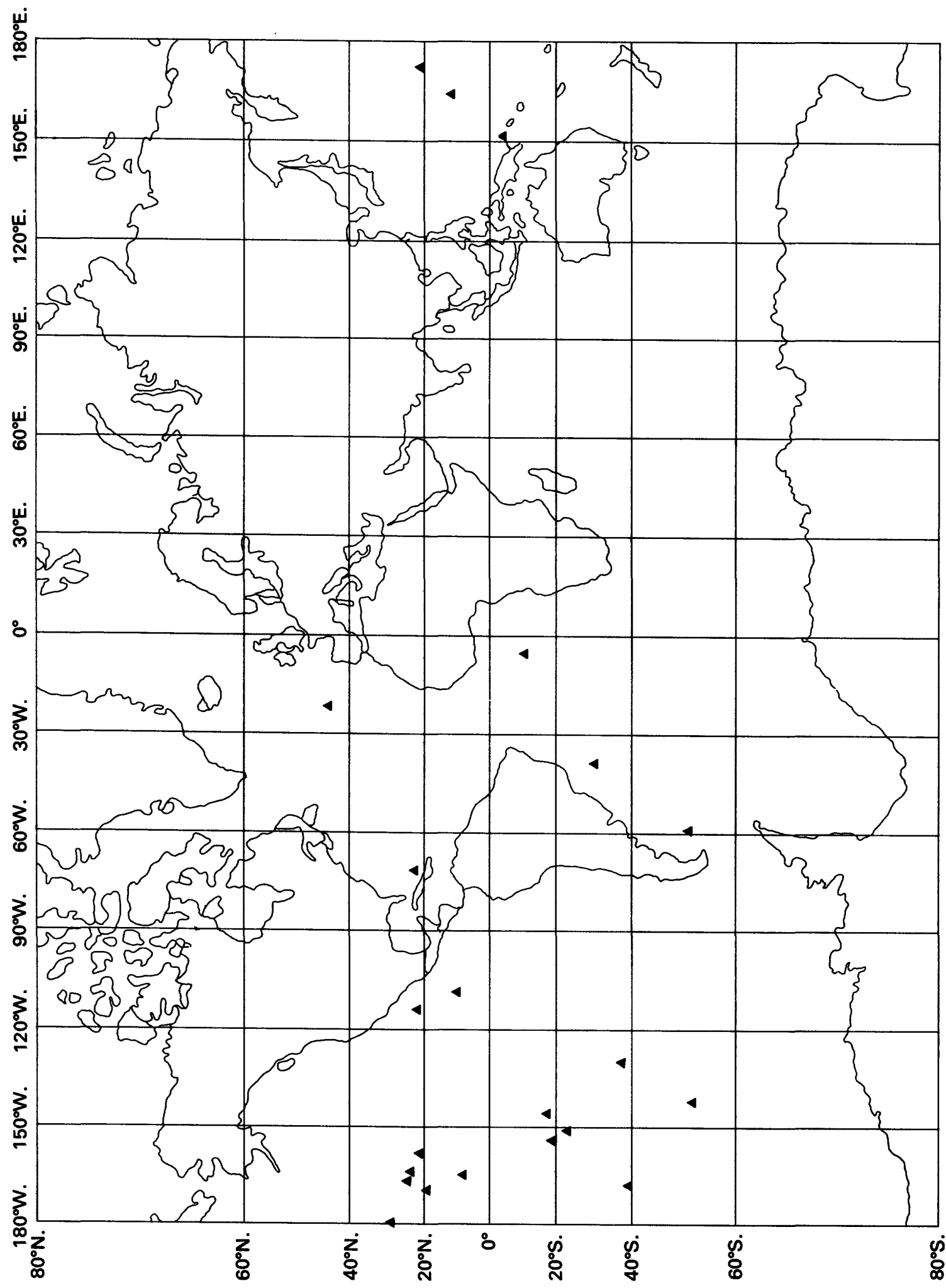

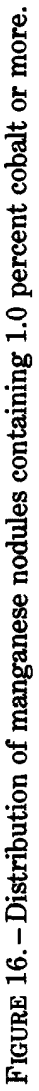




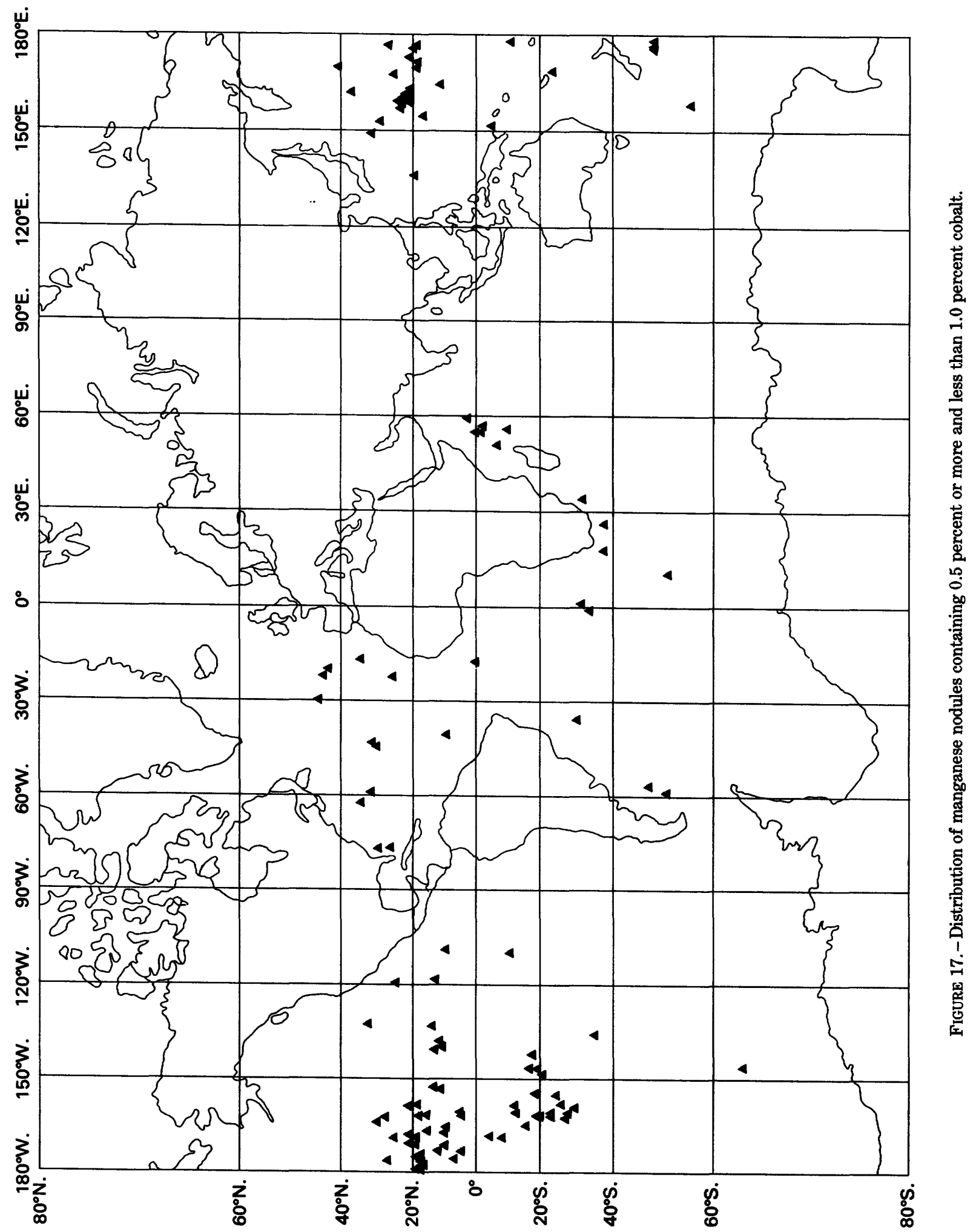




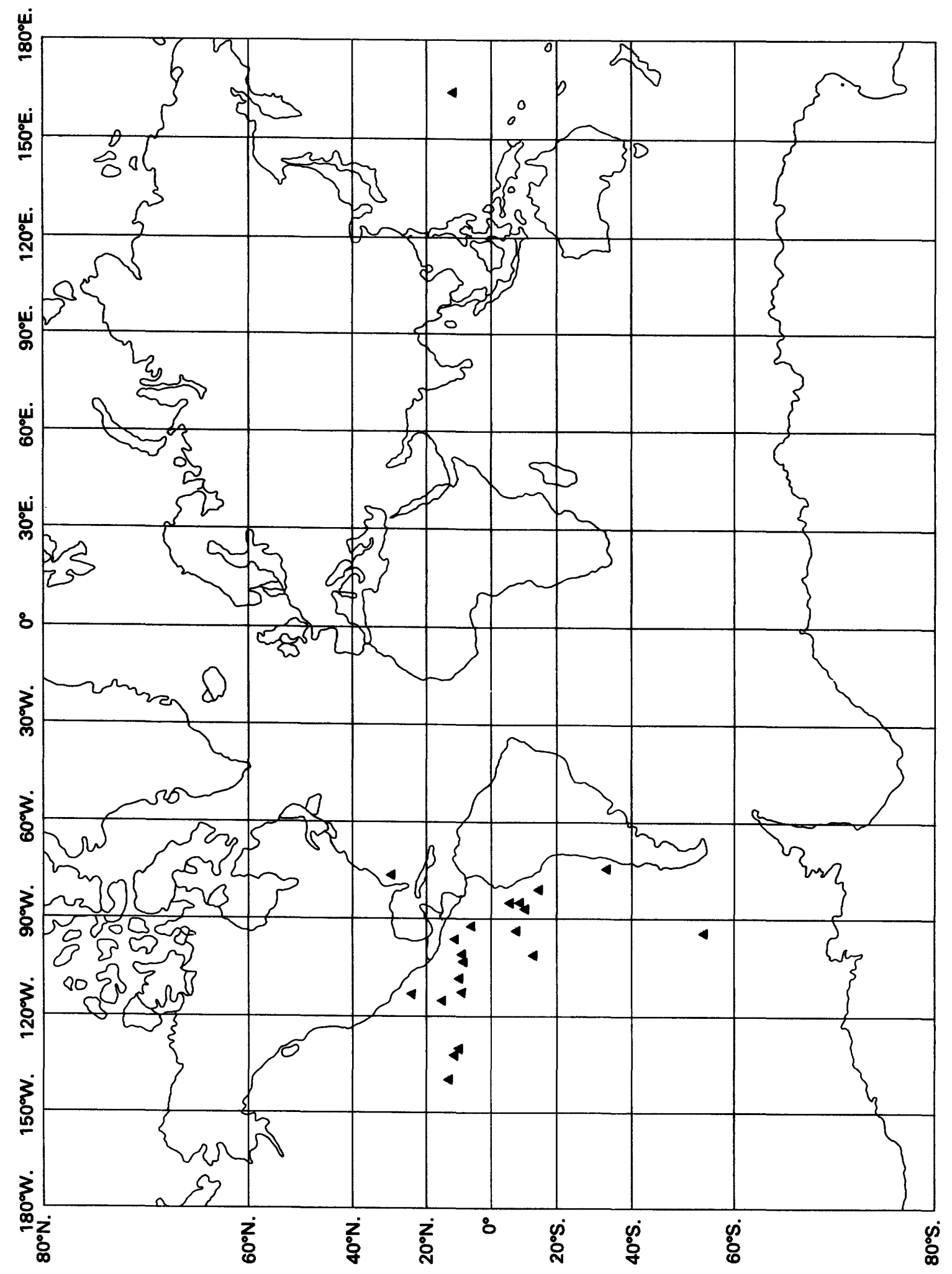

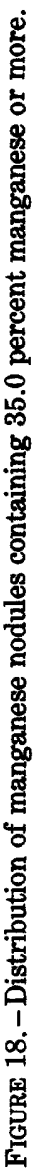


manganese are found along the eastern margin of the Pacific basin, Skornyakova (1979) reported that those rich in iron are from its western margin, where they have concentrations as high as 70 percent $\mathrm{Fe}_{2} \mathrm{O}_{3}$ and manganese-iron ratios of less than 1 (see also Price and Calvert, 1970).

\section{TARGETS FOR EXPLORATION}

The Clarion-Clipperton zone of the northwestern equatorial Pacific is the largest and most promising area known to have nodules rich in nickel and copper; in fact, at this stage, it seems likely that no other area of comparable size containing nodules of comparable quality and concentration will be found. Nevertheless, analysis of the data on the 2,401 stations in the Scripps Sediment Data Bank shows that there are several other areas that appear to contain metal-rich nodules, including some that might be high enough in combined nickel and copper (that is, 1.8 percent or more) to justify exploration for sites suitable for first-generation mining.

For the purpose of this analysis, the locations of stations falling into the metal types described in the preceding section were plotted on a world map (parts of which are reproduced in this report) as a basis for selecting areas in which nodules might contain 1 percent combined nickel and copper or more and that therefore seemed to deserve further study. The results, shown on the following pages, give some indication of areas that would seem favorable for further exploration. Because data on concentrations outside of the Clarion-Clipperton zone are few, no attempt has been made to estimate tonnage in other areas. Estimates of average grade and of size are given for several areas, but, because the data are sparse, these estimates must be taken as only a rough indication of what may be present in areas that, at this stage, are merely targets for exploration. Nor should it be concluded that the areas identified as warranting further study are the only ones that deserve further exploration. As the maps show, many other areas contain high-quality nodules, and further sampling might show some of these areas to be of minable size.

No consideration has been given here to further identifying exploration areas for nodules rich in cobalt or manganese. The data shown in figures 16,17 , and 18 do suggest, however, that there may be large areas in which such nodules might be found. One of the striking results of this analysis as well as of others is that there appears to be considerable continuity in the combined nickel and copper content of manganese nodules over large areas, and this continuity may hold also for nodules rich in cobalt and in manganese. The data suggest, for example, that one or more such areas in which nodules contain more than 1 percent cobalt may be found in the north-central Pacific between $158^{\circ}$ and $180^{\circ} \mathrm{W}$. This region is the one within which Manheim and others reported cobalt-rich manganese oxide encrustations to "cover nearly the entire exposed surface of the seamounts studied" between depths of 2,500 and $1,200 \mathrm{~m}$. Samples containing more than 35 percent manganese that have been reported along the eastern side of the Pacific basin (fig. 18) may be indicative of large areas of manganese-rich nodules.

Several areas in which nodules have high combined nickel and copper contents have been selected for further analysis; these areas are shown in figures 19,20 , and 21 , along with the average combined nickel and copper contents for all stations within each area. These averages range from 0.72 percent combined nickel and copper in the South Atlantic to 1.56 percent in the central south equatorial Indian Ocean. Figures 22 through 28 are enlarged maps of the same areas within which we have tried to delineate smaller areas of nodules containing more than 1.0 percent and more than 1.8 percent combined nickel and copper. Nodules containing lesser amounts have been included in these smaller areas where the average of that station and the ones adjacent to it is above the cutoff. It must be emphasized that areas thus delineated are significant only as targets for further exploration.

As figures 23, 24, and 27 show, fairly large target areas for nodules containing more than 1.8 percent combined nickel and copper can be identified in the central north equatorial Pacific Ocean, the southeastern equatorial Pacific Ocean, and the central-south equatorial Indian Ocean. If nodule mining becomes possible, the rich resources of the Clarion-Clipperton zone will probably be large enough to support production for several decades. Some time in the distant future, however, it may be feasible to mine lower grade nodules; looking to that possibility, one can identify even larger areas in which the nodules contain $\geq 1.0$ to $<1.8 \mathrm{com}$ bined nickel and copper. 


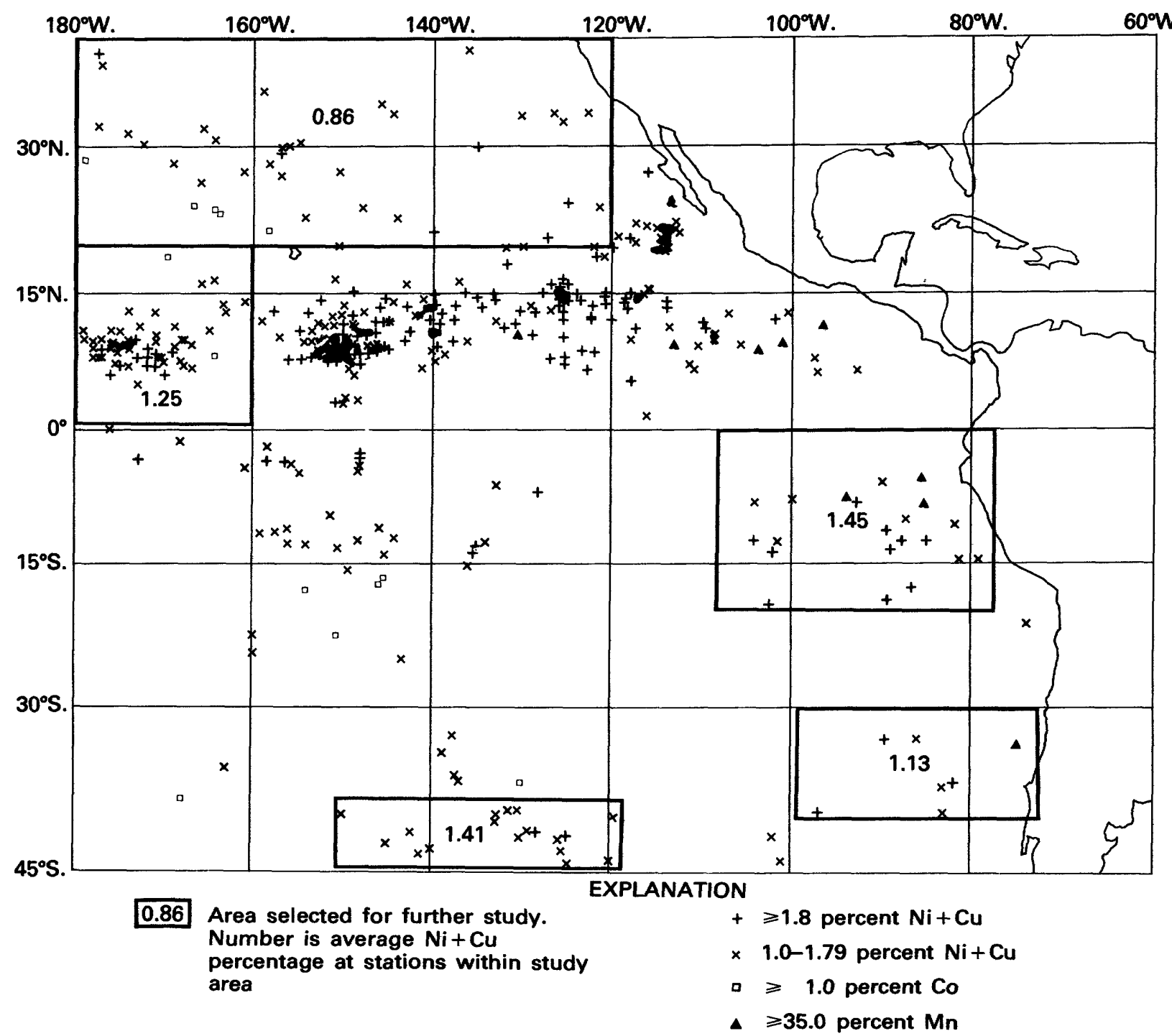

FIGURE 19. - Distribution in the Pacific Ocean of manganese nodules having high metal contents.

As already mentioned, those target areas identified on the maps should not be thought the only ones worth considering. Others can be picked out from figures 14, 18, and 19. For example, a fairsized target for nodules containing more than 1.8 percent combined nickel and copper appears to lie at $154^{\circ}$ to $160^{\circ}$ W., $1^{\circ}$ to $3^{\circ} \mathrm{S}$. in the South Pacific (McKelvey and Wright, 1980); on the basis of recent sampling, Exon (1982) identified this area and others in the central South Pacific between latitudes of $1^{\circ}$ and $7^{\circ} \mathrm{S}$. as having nodules of potential economic significance). The large area at $124^{\circ}$ to $160^{\circ} \mathrm{W} ., 0^{\circ}$ to $18^{\circ} \mathrm{S}$. would be a target for nodules containing more than 1.0 percent combined nickel and copper. Of course, further sampling may disclose other promising areas now unknown.

\section{OTHER ELEMENTS IN MANGANESE NODULES}

Some 51 other elements are present in the analysis of subsea manganese nodules entered in the Scripps Sediment Data Bank in addition to manganese, iron, nickel, copper, and cobalt. Data on these elements, summarized in tables 17 
TABLE 17.-Other elements in manganese nodules of the world and of the Pacific, Atlantic, and Indian Oceans $[-$, no data $]$

\begin{tabular}{|c|c|c|c|c|c|c|c|}
\hline & \multicolumn{4}{|c|}{ World } & \multirow{2}{*}{$\begin{array}{c}\text { Pacific } \\
\text { mean } \\
\text { (percent) }\end{array}$} & \multirow{2}{*}{$\begin{array}{c}\text { Atlantic } \\
\text { mean } \\
\text { (percent) }\end{array}$} & \multirow{2}{*}{$\begin{array}{c}\text { Indian } \\
\text { mean } \\
\text { (percent) }\end{array}$} \\
\hline & $\begin{array}{c}\text { No. of } \\
\text { stations }\end{array}$ & $\begin{array}{c}\text { Mean } \\
\text { (percent) }\end{array}$ & $\begin{array}{c}\text { Range } \\
\text { (percent) }\end{array}$ & $\begin{array}{l}\text { Standard } \\
\text { deviation }\end{array}$ & & & \\
\hline $\mathrm{Li}_{\ldots}$ & 19 & 0.010 & $0.00-0.060$ & 0.014 & 0.02 & - & 0.001 \\
\hline $\mathrm{Be}$ & 40 & .001 & $.00-.010$ & .002 & .001 & - & .001 \\
\hline B & 86 & .029 & $.002-.090$ & .018 & .030 & 0.025 & .007 \\
\hline C _ & 75 & .327 & $.033-1.50$ & .315 & .342 & .77 & .212 \\
\hline $\mathbf{F}$ & 2 & 3.00 & $3.00-3.00$ & 0 & 3.0 & - & 3.0 \\
\hline $\mathrm{Na}$ & 410 & 1.97 & $.30-6.55$ & .82 & 2.05 & 1.86 & 1.70 \\
\hline $\mathrm{Mg}$ & 531 & 1.57 & $.02-5.39$ & .63 & 1.50 & 1.75 & 1.43 \\
\hline $\mathrm{Al}_{-}$ & 592 & 2.70 & $11-8.00$ & 1.30 & 2.75 & 2.37 & 2.67 \\
\hline $\mathrm{Si}$ & 509 & 7.69 & $.24-28.80$ & 4.12 & 7.62 & 6.34 & 9.39 \\
\hline $\mathbf{P}$ & 321 & .37 & $.02-6.03$ & .77 & .28 & .91 & .37 \\
\hline S _ & 106 & .51 & $.05-3.50$ & .71 & .32 & 1.34 & .83 \\
\hline $\mathrm{Cl}$ & 13 & .83 & $.28-1.01$ & .17 & .83 & - & - \\
\hline $\mathrm{K}$ & 490 & .73 & $.11-3.70$ & .45 & .82 & .57 & .48 \\
\hline $\mathrm{Ca}$ & 1,083 & 2.23 & $.02-28.73$ & 2.54 & 1.96 & 3.72 & 1.97 \\
\hline Sc & 76 & .005 & $.00-0.269$ & .031 & .005 & .002 & .001 \\
\hline $\mathrm{Ti}$ & 900 & .69 & $.01-8.90$ & .47 & .73 & .42 & .62 \\
\hline V _ & 437 & .052 & $.001-.500$ & .033 & .051 & .06 & .054 \\
\hline $\mathrm{Cr}$ & 274 & .007 & $.000-.231$ & .024 & .009 & .006 & .002 \\
\hline $\mathrm{Zn}$ & 1,363 & .12 & $.01-9.00$ & .41 & .116 & .123 & .149 \\
\hline Ga & 57 & .001 & $.000-.007$ & .001 & .001 & .001 & .001 \\
\hline $\mathrm{Ge}$ & 4 & .004 & $.000-.009$ & .004 & .004 & - & - \\
\hline As & 63 & .014 & $.002-.048$ & .009 & .011 & .02 & .018 \\
\hline $\mathbf{R b}$ & 32 & .002 & $.000-.006$ & .001 & .002 & - & - \\
\hline $\mathrm{Sr}$ & 369 & .085 & $.001-.285$ & .042 & .084 & .094 & .079 \\
\hline Y _ & 134 & .015 & $.002-.095$ & .013 & .015 & .024 & .011 \\
\hline $\mathrm{Z} r$ & 289 & .057 & $.002-.360$ & .038 & .061 & .056 & .034 \\
\hline $\mathrm{Nb}$ & 68 & .007 & $.001-.030$ & .005 & .007 & .004 & .007 \\
\hline Mo & 836 & .038 & $.002-.220$ & .022 & .041 & .031 & .029 \\
\hline $\mathrm{Ag}$ & 7 & .001 & $.000-.002$ & .001 & .001 & - & - \\
\hline Cd & 129 & .001 & $.000-.003$ & .001 & .001 & .001 & .001 \\
\hline $\mathrm{Sn}$ & 141 & .008 & $.000-.040$ & .008 & .010 & .007 & .001 \\
\hline $\mathrm{Sb}$ & 10 & .005 & $.004-.005$ & .000 & .005 & .004 & - \\
\hline $\mathrm{Te}$ & 17 & .022 & $.017-.027$ & .003 & .022 & - & - \\
\hline I _ _ & 1 & .250 & - & - & .25 & - & - \\
\hline $\mathrm{Ba}$ & 463 & .23 & $.000-2.14$ & .21 & .235 & .228 & .21 \\
\hline La & 75 & .021 & $.009-.070$ & .012 & .022 & .023 & .018 \\
\hline $\mathrm{Ce}$ & 72 & .072 & $.009-.300$ & .059 & .069 & - & .125 \\
\hline $\mathrm{Nd}$ & 37 & .026 & $.007-.070$ & .014 & .027 & - & .011 \\
\hline $\mathrm{Sm}$ & 38 & .004 & $.002-.011$ & .002 & .004 & - & .004 \\
\hline $\mathbf{E u}$ & 38 & .001 & $.000-.002$ & .000 & .001 & - & .001 \\
\hline $\mathrm{Tb}$ & 36 & .001 & $.000-.002$ & .000 & .001 & - & .001 \\
\hline $\mathrm{Yb}$ & 101 & .003 & $.001-.010$ & .001 & .003 & .003 & .001 \\
\hline Lu & 32 & .000 & $.000-.001$ & .000 & .000 & - & .000 \\
\hline Hf & 8 & .001 & $.000-.001$ & .000 & .001 & - & - \\
\hline Ta & 9 & .002 & $.000-.002$ & .001 & .002 & - & - \\
\hline W & 22 & .010 & $.003-.060$ & .011 & .008 & - & .012 \\
\hline $\mathrm{Hg}$ & 1 & .000 & - & - & .000 & - & - \\
\hline Tl & 130 & .016 & $.000-.061$ & .010 & .017 & .018 & .008 \\
\hline $\mathrm{Pb}$ & 1,246 & .093 & $.01-.75$ & .067 & .083 & .14 & .101 \\
\hline Bi & 41 & .002 & $.000-.009$ & .002 & .003 & .001 & .001 \\
\hline Th & 121 & .003 & $.000-.013$ & .002 & .003 & - & .003 \\
\hline
\end{tabular}

through 20, follow the general structure adopted in the presentation of data on principal metals.

The world mean contents (table 17) of sodium (1.97 percent), magnesium (1.57), aluminum (2.70), silicon (7.69), and calcium (2.23) exceed 1.5 percent in the nodules; the sum of the oxides of these elements at their mean values is about 30 percent.
In the $\geq 0.1$ - to $<1.5$-percent range are the means of carbon (0.327 percent), phosphorus ( 0.37$)$, sulfur $(0.51)$, chlorine $(0.83)$, potassium $(0.73)$, titanium $(0.69)$, zinc (0.12), and barium (0.23). The means of 12 other elements (lithium, vanadium, strontium, yttrium, zirconium, molybdenum, tellurium, lanthanum, cerium, neodymium, and lead) are in the 


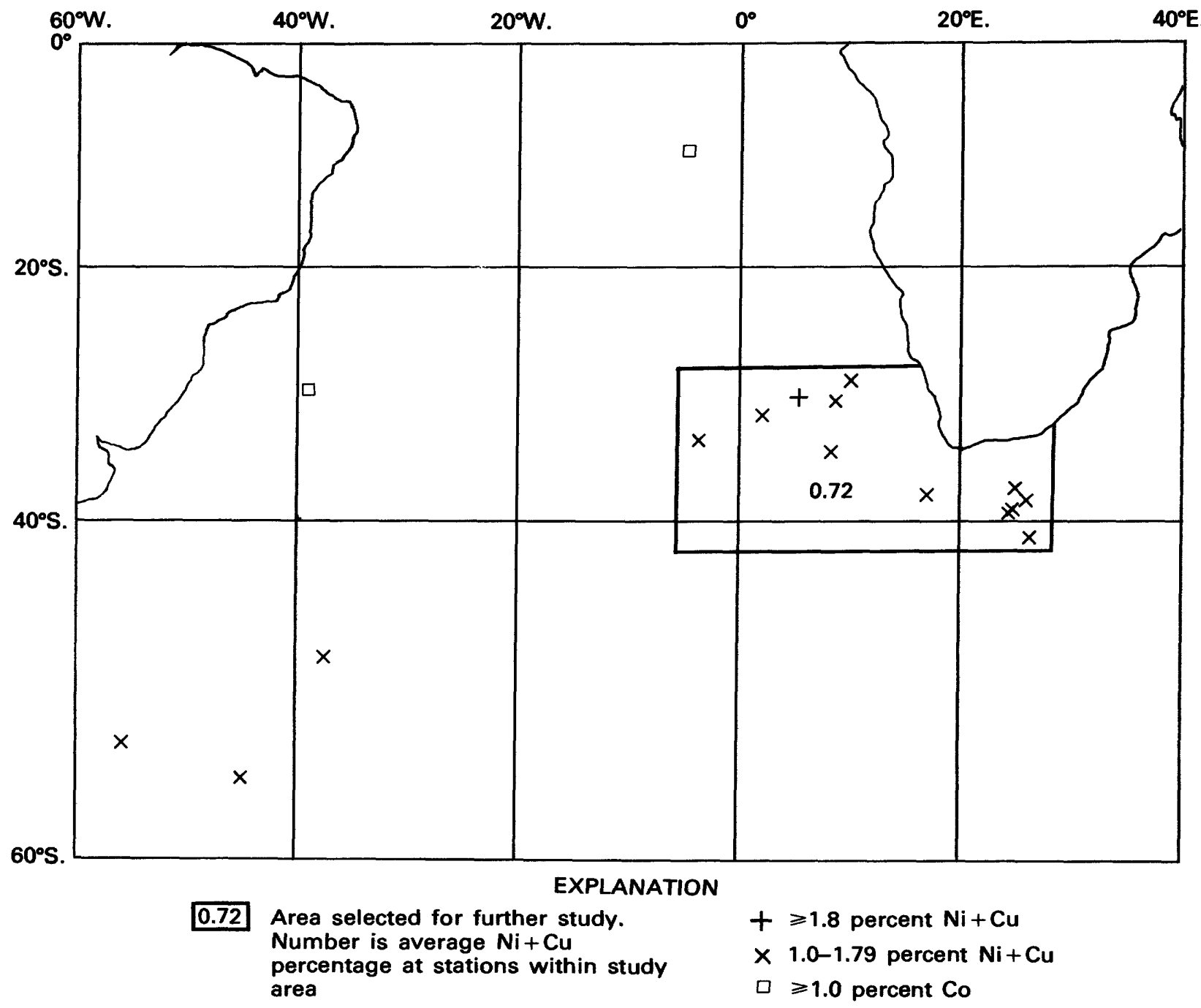

FIGURE 20.-Distribution in the South Atlantic Ocean of manganese nodules having high metal contents.

range of $\leq 0.01$ to $<0.1$ percent. Although the mean concentrations of these elements in nodules are all much lower than those in the deposits from which they are mined on land, many represent substantial geochemical concentrations. For example, in comparison with the averages estimated by Lee and Yao (1970) for oceanic crust, the mean for zinc in nodules is 10 times greater, that for lead is 93 times greater, and that for molybdenum is 253 times greater. Even though their amounts are relatively small, some of these minor metals for which the price is relatively high conceivably might be recovered as byproducts in the extraction of nickel and copper.

Analyses available for other elements are fewer than those available for the metals previously discussed. Given this limitation, it nevertheless appears that regional variations similar to those observed for the principal metals occur in the contents of some other elements. If only elements for which the station population in each ocean is 10 or more are considered, the means for phosphorus, calcium, and yttrium in Atlantic nodules are more than 20 percent higher than the world mean, and those for potassium and titanium are more than $\mathbf{2 0}$ percent lower (table 17). The means for silica, arsenic, and cerium are more than 20 percent higher than the world mean in the Indian Ocean, and those for lithium, carbon, zirconium, potassium, molybdenum, and tin are more than 20 percent lower. Because stations in the Pacific are much more numerous than those in other oceans, 
TABLE 18.-Means of other elements (in percent) in manganese nodules of the world, grouped by latitude $[-$, no data. Values set in italics are based on 10 stations or more]

\begin{tabular}{|c|c|c|c|c|c|c|c|}
\hline Element & $60^{\circ}-40^{\circ} \mathrm{N}$. & $40^{\circ}-20^{\circ} \mathrm{N}$ & $20^{\circ}$ N. $-0^{\circ}$ & $0^{\circ}-20^{\circ} \mathrm{S}$ & $20^{\circ}-40^{\circ} \mathrm{S}$. & $40^{\circ}-60^{\circ} \mathrm{S}$ & $60^{\circ}-80^{\circ} \mathrm{S}$ \\
\hline $\mathrm{Li}$ & - & 0.02 & 0.001 & 0.001 & - & - & _- \\
\hline $\mathrm{Be}$ & 0.000 & .000 & .000 & .001 & 0.001 & 0.002 & - \\
\hline B & .028 & .026 & .02 & .029 & .022 & .043 & - \\
\hline C & .26 & .29 & .22 & .30 & .412 & .682 & - \\
\hline F & - & - & 3.0 & - & 3.00 & - & - \\
\hline $\mathrm{Na}$ & 1.64 & 1.87 & 1.84 & 2.30 & 1.96 & 2.37 & 1.96 \\
\hline Mg & 1.72 & 1.61 & 1.57 & 1.40 & 1.42 & 1.58 & 2.64 \\
\hline $\mathrm{Al}$ & 2.81 & 2.61 & 2.58 & 2.56 & 3.28 & 2.46 & 3.18 \\
\hline 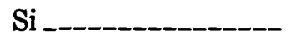 & 12.15 & 7.04 & 7.42 & 7.58 & 8.07 & 8.68 & 13.83 \\
\hline $\mathbf{P}_{-}$ & .26 & .50 & .28 & .18 & .47 & .86 & - \\
\hline$S_{-}$ & .73 & .51 & .26 & .64 & .82 & .51 & \\
\hline $\mathrm{Cl}^{-}$ & - & .86 & - & - & .90 & .28 & - \\
\hline K & .57 & .71 & .74 & .83 & .64 & .86 & .964 \\
\hline $\mathrm{Ca}$ & 2.19 & 3.30 & 1.87 & 2.07 & 2.12 & 1.82 & 2.25 \\
\hline Sc - & .001 & .002 & .023 & .001 & .003 & .002 & - \\
\hline $\mathrm{Ti}$ & .53 & .66 & .64 & .76 & .880 & .623 & .639 \\
\hline V & .042 & .055 & .046 & .056 & .049 & .059 & .041 \\
\hline $\mathrm{Cr}$ & .004 & .012 & .011 & .001 & .002 & .004 & - \\
\hline Zn & .06 & .12 & .11 & .13 & .17 & .10 & .06 \\
\hline $\mathrm{Ga}$ & .002 & .001 & .001 & .001 & .002 & .001 & - \\
\hline Ge - & - & .004 & - & .000 & .009 & - & - \\
\hline As & .01 & .019 & .009 & .016 & .018 & .015 & - \\
\hline $\mathrm{Rb}$ & .003 & .003 & .001 & .001 & - & - & - \\
\hline Sr & .084 & .097 & .082 & .071 & .087 & .082 & .084 \\
\hline Y & .028 & .016 & .015 & .015 & .013 & .013 & - \\
\hline $\mathrm{Zr}$ & .040 & .062 & .042 & .057 & .036 & .072 & .073 \\
\hline $\mathrm{Nb}$ & .005 & .009 & .004 & .010 & .004 & .005 & - \\
\hline Mo _- & .038 & .040 & .046 & .031 & .031 & .037 & .031 \\
\hline $\mathrm{Ag}$ & - & .001 & - & .001 & .002 & - & - \\
\hline Cd & .000 & .001 & .001 & .001 & .001 & .002 & - \\
\hline Sn & .000 & .005 & .001 & .004 & .010 & .009 & .008 \\
\hline Sb _-_- & - & .005 & - & - & - & - & - \\
\hline $\mathrm{Te}$ & - & .022 & - & .020 & - & - & - \\
\hline I & - & - & .25 & - & - & - & - \\
\hline $\mathrm{Ba}$ & .291 & .37 & .267 & .173 & .234 & .136 & .109 \\
\hline La & .018 & .02 & .027 & .020 & .020 & .017 & - \\
\hline $\mathrm{Ce}$ & .053 & .10 & .058 & .065 & .126 & .045 & - \\
\hline Nd & .018 & .027 & .034 & .020 & .020 & .030 & - \\
\hline Sm - & .004 & .004 & .006 & .003 & .004 & .004 & - \\
\hline $\mathrm{Eu}$ & .001 & .001 & .001 & .001 & .001 & .001 & _- \\
\hline Tb & .001 & .001 & .001 & .001 & .001 & .002 & - \\
\hline Yb & .002 & .003 & .003 & .003 & .003 & .003 & - \\
\hline $\mathrm{Lu}$ & .000 & .000 & .000 & .000 & .000 & .000 & - \\
\hline Hf & - & .001 & - & - & - & - & - \\
\hline $\mathrm{Ta}$ & - & - & - & .002 & - & - & _- \\
\hline W & - & .003 & - & .011 & .009 & - & - \\
\hline $\mathrm{Hg}$ & - & - & - & .000 & - & - & - \\
\hline Tl & .010 & .018 & .016 & .016 & .014 & .012 & - \\
\hline $\mathrm{Pb}$ & .120 & .103 & .067 & .09 & .12 & .14 & .16 \\
\hline $\mathrm{Bi}$ & .001 & .003 & .004 & .002 & .002 & .003 & - \\
\hline Th & .008 & .002 & .002 & .003 & .005 & .004 & - \\
\hline
\end{tabular}

they strongly influence the world mean for most elements, and significant departures from the world mean are not to be expected in Pacific nodules. Even so, the mean for chromium in Pacific nodules is 28 percent higher than the world mean (and 4.5 times higher than that in Indian Ocean nodules), and sulfur is 38 percent lower.

As for latitudinal variations (table 18), the means for magnesium and lead decrease toward the equatorial region. Overall, but departing from the trend in one or more intermediate zones, so do the means for boron, carbon, aluminum, silicon, and calcium; the means for phosphorus, sulfur, chromium, and yttrium also decrease toward the equator in one hemisphere or the other. On the other hand, the means for potassium, titanium, vanadium, zinc, and molybdenum generally increase toward the equator, although there are 
$40^{\circ} \mathrm{E}$.

$60^{\circ} \mathrm{E}$.

$80^{\circ} \mathrm{E}$.

$100^{\circ} \mathrm{E}$.

$120^{\circ} \mathrm{E}$.

$140^{\circ} \mathrm{E}$.

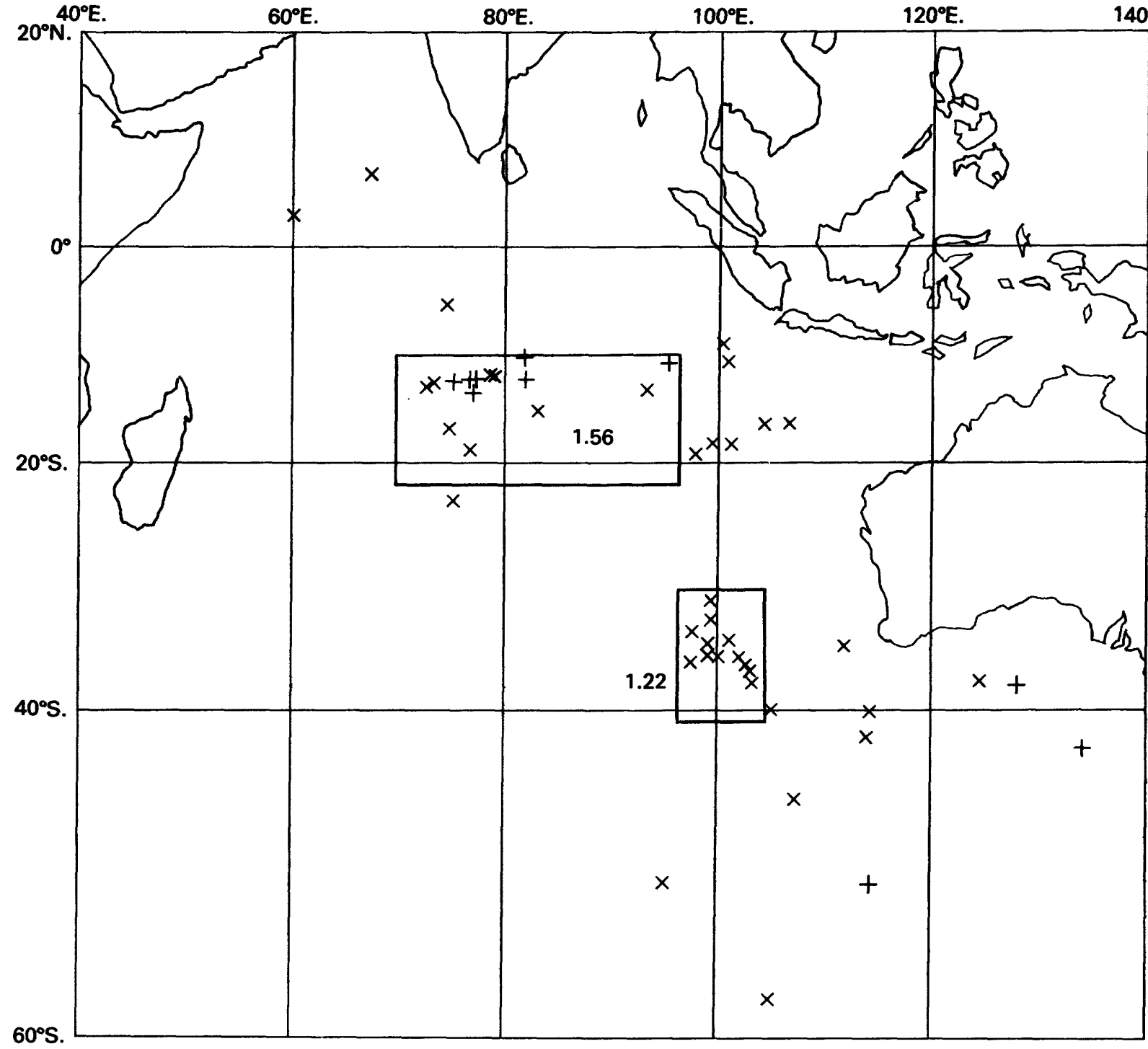

EXPLANATION

1.56 Area selected for further study.

Number is average $\mathrm{Ni}+\mathrm{Cu}$

percentage at stations within study

area

$+\quad \geqslant 1.8$ percent $\mathrm{Ni}+\mathrm{Cu}$

X 1.0-1.79 percent $\mathrm{Ni}+\mathrm{Cu}$

FIGURE 21.-Distribution in the Indian Ocean of manganese nodules having high metal contents.

some departures from the trend in intermediate latitudinal zones.

Again, if we compare only those elements that have been analyzed at 10 stations or more in populations above and below the 3,000-m depth (table 19), aluminum, silicon, potassium, scandium, and samarium are enriched in nodules below that depth, and boron, phosphorus, sulfur, calcium, vanadium, chromium, arsenic, strontium, yttrium, tin, barium, cerium, and lead are enriched in nodules above it. Means for several other elements - for example, sodium, magnesium, zinc, zirconium, molybdenum, and lanthanum - are about the same in both groups. 
TABLE 19.-Means of other elements in manganese nodules in water depths above and below $3,000 \mathrm{~m}$

$[-$, no data $]$

\begin{tabular}{|c|c|c|c|c|}
\hline \multirow[b]{2}{*}{ Elements } & \multicolumn{2}{|c|}{$<3,000 \mathrm{~m}$} & \multicolumn{2}{|c|}{$>3,000 \mathrm{~m}$} \\
\hline & $\begin{array}{l}\text { No. of } \\
\text { stations }\end{array}$ & $\begin{array}{c}\text { Mean } \\
\text { (percent) }\end{array}$ & $\begin{array}{c}\text { No. of } \\
\text { stations }\end{array}$ & $\begin{array}{c}\text { Mean } \\
\text { (percent) }\end{array}$ \\
\hline - & $\mathbf{5}$ & 0.001 & 14 & 0.013 \\
\hline $\mathrm{Be}$ & 10 & .001 & 30 & .001 \\
\hline B _-_____ & 33 & .040 & 52 & .022 \\
\hline C _ & 2 & .91 & 68 & .311 \\
\hline $\mathbf{F}$ & 1 & 3.00 & 1 & 3.00 \\
\hline $\mathrm{Na}$ & 98 & 1.83 & 310 & 2.02 \\
\hline Mg _ _- & 125 & 1.61 & 403 & 1.553 \\
\hline $\mathrm{Al}$ & 103 & 1.72 & 478 & 2.95 \\
\hline $\mathrm{Si}$ & 94 & 5.07 & 399 & 8.29 \\
\hline $\mathbf{P}$ & 51 & 1.148 & 265 & .22 \\
\hline - - - - - & 12 & .85 & 92 & .43 \\
\hline _- & 0 & - & 13 & .83 \\
\hline - - - - - - & 119 & .47 & 368 & .81 \\
\hline $\mathrm{Ca}$ & 188 & 4.65 & 883 & 1.72 \\
\hline Se _-_-_-_ & 21 & .001 & 54 & .007 \\
\hline $\mathrm{Ti}$ & 136 & .76 & 748 & .68 \\
\hline $\mathrm{V}$ & 68 & .071 & 367 & .049 \\
\hline $\mathrm{Cr}$ & 52 & .015 & 221 & .006 \\
\hline $\mathrm{Zn}$ & 188 & .11 & 1,118 & .12 \\
\hline Ga & 15 & .001 & 41 & .001 \\
\hline Ge _- & 0 & - & 4 & .004 \\
\hline As _- & 14 & .020 & 47 & .012 \\
\hline $\mathrm{Rb}$ & 0 & - & 32 & .002 \\
\hline $\mathrm{Sr}$ & 77 & .122 & 290 & .075 \\
\hline$Y_{-}$ & 36 & .024 & 96 & .012 \\
\hline $\mathrm{Zr}$ & 46 & .057 & 239 & .057 \\
\hline $\mathrm{Nb}$ & 15 & .005 & 52 & .008 \\
\hline Mo ___-____ & 118 & .045 & 710 & .037 \\
\hline $\mathrm{Ag}$ & 0 & - & 7 & .001 \\
\hline $\mathrm{Cd}$ & 23 & .001 & 102 & .001 \\
\hline $\mathrm{Sn}$ & 19 & .004 & 122 & .009 \\
\hline $\mathrm{Sb}$ & 1 & .004 & 8 & .005 \\
\hline $\mathrm{Te}$ & 0 & - & 17 & .022 \\
\hline I _-_-_-_-_ & 0 & - & 1 & .25 \\
\hline $\mathrm{Ba}$ & 63 & .34 & 398 & .22 \\
\hline La _- & 33 & .022 & 42 & .021 \\
\hline $\mathrm{Ce}$ & 15 & .087 & 57 & .068 \\
\hline $\mathrm{Nd}$ & 13 & .021 & 24 & .028 \\
\hline Sm _-_-_- & 13 & .003 & 25 & .005 \\
\hline Eu ___ & 13 & .001 & 25 & .001 \\
\hline $\mathrm{Tb}$ & 11 & .001 & 25 & .001 \\
\hline $\mathrm{Yb}$ & 36 & .004 & 64 & .002 \\
\hline Lu _. & 13 & .000 & 19 & .000 \\
\hline Hf & 0 & - & 8 & .001 \\
\hline $\mathrm{Ta}$ & 0 & - & 9 & .002 \\
\hline $\mathrm{W}$ & 0 & - & 22 & .010 \\
\hline Hg _- & 0 & - & 1 & .000 \\
\hline $\mathrm{Tl}$ & 24 & .018 & 101 & .016 \\
\hline $\mathrm{Pb}$ & 197 & .14 & 1,029 & .08 \\
\hline $\mathrm{Bi}$ & 9 & .002 & 31 & .003 \\
\hline Th ___ & 13 & .002 & 105 & .003 \\
\hline
\end{tabular}

Examination of the distribution of other elements in nodules typed by their high contents of combined nickel and copper, manganese, and cobalt (table 20) indicates that several other elements follow these metals in their variations. The mean values of magnesium, aluminum, silicon, potassium, scandium, chromium, and zinc in the 21.8-percent combined nickel and copper groups are appreciably higher than those in the $\geq 0.5$-percent cobalt groups. The highest means for magnesium (1.87 percent), scandium $(0.018)$, and chromium $(0.013)$ are in the $\geq 1.8$-percent combined nickel and copper group, which also has the lowest mean values for sulfur (0.22 percent), calcium (1.59), titanium (0.47), strontium (0.06), yttrium (0.011), zirconium (0.049), lanthanum (0.013), cerium (0.035), and lead $(0.048)$; the mean for vanadium (0.043) in this group is also appreciably lower than that in the $\geq 0.5$-percent cobalt group but is about the same as that in the $\geq 35$.0-percent manganese group. The $\geq 0.5$-percent cobalt groups have the highest means for phosphorus (0.531 percent), calcium (2.83), titanium (1.07), vanadium (0.069), strontium (0.14), yttrium (0.031), zirconium (0.072), lanthanum (0.027), cerium (0.133), and lead $(0.26)$ and the lowest means for magnesium (1.337 percent), aluminum (0.71), silicon (2.00, at six stations only, however), potassium (0.32), and zinc (0.07). The $\geq 35$.0-percent manganese group has the highest means for sodium (2.77 percent, at 9 stations only), and barium (0.423) and the lowest means for phosphorus ( 0.120 percent, at 7 stations only), titanium (0.253), and vanadium ( 0.041 , at 8 stations only); the mean for silicon (4.68 percent) in this group is appreciably lower than that in the high combined nickel and copper groups, and it is lower also than the silicon mean (5.18 percent) in the $\geq 0.5$ - to $<1.0$-percent cobalt group.

Average contents of the other elements in Clarion-Clipperton zone nodules are essentially the same as those in $\geq 1.8$-percent combined nickel and copper group nodules-expectably so, because Clarion-Clipperton zone stations are the largest population within that group and strongly influence its mean values. The means for calcium (1.56 percent), vanadium (0.03), and zirconium (0.036) in Clarion-Clipperton zone nodules, however, are appreciably lower than those in the $\geq 1$.8-percent combined nickel and copper group; the mean for chromium (0.02) is appreciably higher.

Although the covariance of other elements with the principal metals in manganese nodules supports the idea that the metal groups described are geochemically distinct, the metal groups do not include the maximum values for several other elements-namely, titanium (8.9 percent), phosphorus (6.03), sulfur (3.50), potassium (3.70), 
TABLE 20.-Other elements in manganese nodules grouped by combined nickel and copper, manganese, and cobalt contents

\begin{tabular}{|c|c|c|c|c|c|c|c|c|c|c|}
\hline & \multicolumn{2}{|c|}{$\geq 1.8$ percent $\mathrm{Ni}+\mathrm{Cu}$} & \multicolumn{2}{|c|}{$\begin{array}{c}\geq 1.0-<1.8 \text { percent } \\
\mathrm{Ni}+\mathrm{Cu} \\
\end{array}$} & \multicolumn{2}{|c|}{$\begin{array}{l}\geq 35.0 \text { percent } \\
\text { Mn }\end{array}$} & \multicolumn{2}{|c|}{$\begin{array}{l}\geq 1.0 \text { percent } \\
\text { Co }\end{array}$} & \multicolumn{2}{|c|}{$\begin{array}{l}\geq 0.5-<1.0 \\
\text { percent Co }\end{array}$} \\
\hline & $\begin{array}{c}\text { No. of } \\
\text { stations }\end{array}$ & $\begin{array}{c}\text { Mean } \\
\text { (percent) }\end{array}$ & $\begin{array}{l}\text { No. of } \\
\text { stations }\end{array}$ & $\begin{array}{c}\text { Mean } \\
\text { (percent) }\end{array}$ & $\begin{array}{c}\begin{array}{c}\text { No. of } \\
\text { stations }\end{array} \\
\end{array}$ & $\begin{array}{c}\text { Mean } \\
\text { (percent) }\end{array}$ & $\begin{array}{l}\begin{array}{c}\text { No of } \\
\text { stations }\end{array} \\
\end{array}$ & $\begin{array}{c}\text { Mean } \\
\text { (percent) }\end{array}$ & $\begin{array}{l}\text { No. of } \\
\text { stations }\end{array}$ & $\begin{array}{c}\text { Mean } \\
\text { (percent) }\end{array}$ \\
\hline Li & 4 & 0.018 & 5 & 0.020 & 0 & - & 0 & - & 2 & 0.000 \\
\hline $\mathrm{Be}$ & 6 & .0002 & 12 & .000 & 0 & - & 0 & - & 6 & .001 \\
\hline$B_{2}$ & 15 & .02 & 20 & .027 & 6 & 0.016 & 5 & 0.041 & 9 & .032 \\
\hline$C_{2}$ & 15 & .23 & 22 & .321 & 1 & .93 & 0 & - & 2 & .080 \\
\hline F & 0 & - & 1 & 3.00 & 0 & - & 0 & - & 1 & 3.0 \\
\hline $\mathrm{Na}$ & 46 & 2.02 & 67 & 1.97 & 9 & 2.77 & 7 & 1.99 & 37 & 1.80 \\
\hline Mg & 78 & 1.87 & 91 & 1.57 & 9 & 1.67 & 8 & 1.47 & 47 & 1.337 \\
\hline Al & 120 & 2.65 & 111 & 2.96 & 11 & 2.09 & 12 & .71 & 46 & 1.81 \\
\hline $\mathrm{Si}$ & 111 & 6.98 & 111 & 8.26 & 11 & 4.68 & 6 & 2.00 & 39 & 5.18 \\
\hline$P_{2}$ & 61 & .21 & 70 & .288 & 7 & .120 & 4 & .32 & 23 & .531 \\
\hline S & 27 & .22 & 32 & .319 & 3 & .547 & 1 & 1.2 & 3 & 1.199 \\
\hline $\mathrm{Cl}$ & 4 & .86 & 5 & .860 & 0 & - & 0 & - & 0 & - \\
\hline $\mathrm{K}$ & 73 & .79 & 80 & .86 & 10 & .72 & 8 & .32 & 43 & .49 \\
\hline $\mathrm{Ca}$ & 279 & 1.59 & 191 & 1.73 & 14 & 1.64 & 11 & 2.72 & 81 & 2.83 \\
\hline Sc & 16 & .018 & 19 & .001 & 3 & .001 & 4 & .001 & 8 & .001 \\
\hline $\mathrm{Ti}$ & 169 & .47 & 169 & .58 & 16 & .253 & 16 & 1.07 & 80 & 1.01 \\
\hline V & 69 & .043 & 95 & .05 & 8 & .041 & 9 & .069 & 34 & .064 \\
\hline $\mathrm{Cr}$ & 62 & .013 & 55 & .001 & 5 & .001 & 3 & .002 & 28 & .001 \\
\hline $\mathrm{Zn}$ & 371 & .14 & 267 & .14 & 11 & .08 & 12 & .07 & 85 & .14 \\
\hline $\mathrm{Ga}$ & 10 & .002 & 16 & .001 & 4 & .001 & 1 & .002 & 4 & .001 \\
\hline Ge & 0 & - & 1 & .000 & 0 & - & 0 & - & 0 & - \\
\hline As & 19 & .008 & 14 & .012 & 1 & .002 & 1 & .027 & 7 & .016 \\
\hline $\mathrm{Rb}$ & 18 & .002 & 8 & .001 & 0 & - & 0 & - & 3 & .001 \\
\hline $\mathrm{Sr}$ & $\mathbf{5 5}$ & .06 & 80 & .077 & 8 & .070 & 7 & .14 & 27 & .119 \\
\hline$Y_{-}$ & 33 & .011 & 32 & .012 & 5 & .007 & $\mathbf{5}$ & .031 & 14 & .021 \\
\hline $\mathrm{Zr}$ & 43 & .049 & 55 & .050 & 6 & .033 & 6 & .072 & 18 & .061 \\
\hline $\mathrm{Nb}$ & 7 & .007 & 17 & .007 & 1 & .001 & 1 & .007 & 7 & .006 \\
\hline Mo & 186 & .05 & 175 & .039 & 13 & .056 & 11 & .060 & 63 & .048 \\
\hline $\mathrm{Ag}$ & 0 & - & 3 & .001 & 0 & - & 0 & - & 0 & - \\
\hline $\mathrm{Cd}$ & 29 & .002 & 28 & .001 & 0 & - & 1 & .000 & 15 & .001 \\
\hline $\mathrm{Sn}$ & 6 & .010 & 26 & .009 & 1 & .009 & 2 & .022 & 5 & .004 \\
\hline $\mathrm{Sb}$ & 4 & .004 & 4 & .005 & 0 & - & 0 & - & 0 & - \\
\hline Te & 5 & .024 & 9 & .021 & 0 & - & 0 & - & 1 & .021 \\
\hline I & 1 & .25 & 0 & - & 0 & - & 0 & - & 0 & - \\
\hline $\mathrm{Ba}$ & 78 & .288 & 101 & .224 & 10 & .423 & 8 & .333 & 39 & .286 \\
\hline $\mathrm{La}$ & 11 & .013 & 15 & .019 & 1 & .018 & 6 & .024 & 13 & .027 \\
\hline $\mathrm{Ce}$ & 22 & .035 & 15 & .066 & 0 & - & 2 & .133 & 10 & .098 \\
\hline $\mathrm{Nd}$ & 4 & .021 & 7 & .023 & 0 & - & 2 & .032 & 5 & .034 \\
\hline $\mathrm{Sm}$ & $\mathbf{5}$ & .003 & 10 & .004 & 0 & - & 2 & .005 & 4 & .006 \\
\hline $\mathrm{Eu}$ & 5 & .001 & 10 & .001 & 0 & - & 2 & .001 & 4 & .001 \\
\hline $\mathrm{Tb}$ & $\mathbf{5}$ & .001 & 10 & .001 & 0 & - & 1 & .000 & 4 & .001 \\
\hline $\mathrm{Yb}$ & 17 & .002 & 22 & .002 & 5 & .002 & 6 & .005 & 12 & .004 \\
\hline $\mathrm{Lu}$ & 2 & .000 & 7 & .000 & 0 & - & 2 & .001 & 4 & .000 \\
\hline Hf & 4 & .001 & 4 & .001 & 0 & - & 0 & - & 0 & - \\
\hline Ta & 0 & - & 0 & - & 0 & - & 0 & - & 0 & - \\
\hline W & 1 & .003 & 2 & .004 & 0 & - & 0 & - & 0 & - \\
\hline $\mathrm{Hg}$ & 0 & - & 0 & - & 0 & - & 0 & - & 0 & - \\
\hline Tl & 25 & .02 & 24 & .013 & 1 & .000 & 2 & .037 & 15 & .020 \\
\hline $\mathrm{Pb}$ & 301 & .048 & 229 & .071 & 19 & .09 & $1 \overline{2}$ & .26 & 95 & .17 \\
\hline $\mathrm{Bi}$ & 1 & .001 & 9 & .002 & 0 & - & 2 & .003 & 4 & .003 \\
\hline Th & 39 & .002 & 24 & .003 & 1 & .005 & 1 & .001 & 10 & .003 \\
\hline
\end{tabular}

calcium (28.73), scandium (0.269), vanadium (0.5), zinc (9.00), molybdenum (0.220), barium (2.14), lanthanum $(0.07)$, cerium $(0.30)$, yttrium $(0.095)$, neodymium (0.07), and lead (0.75). Because many of these maximums are an order of magnitude or more larger than the means, one might suspect that they are simply erroneous. That this explanation may not be valid, however, is suggested by the fact that their maximums in each ocean are also much higher than the world mean (table 21). For example, the world maximum for titanium comes from the Pacific, but the highest values in the 


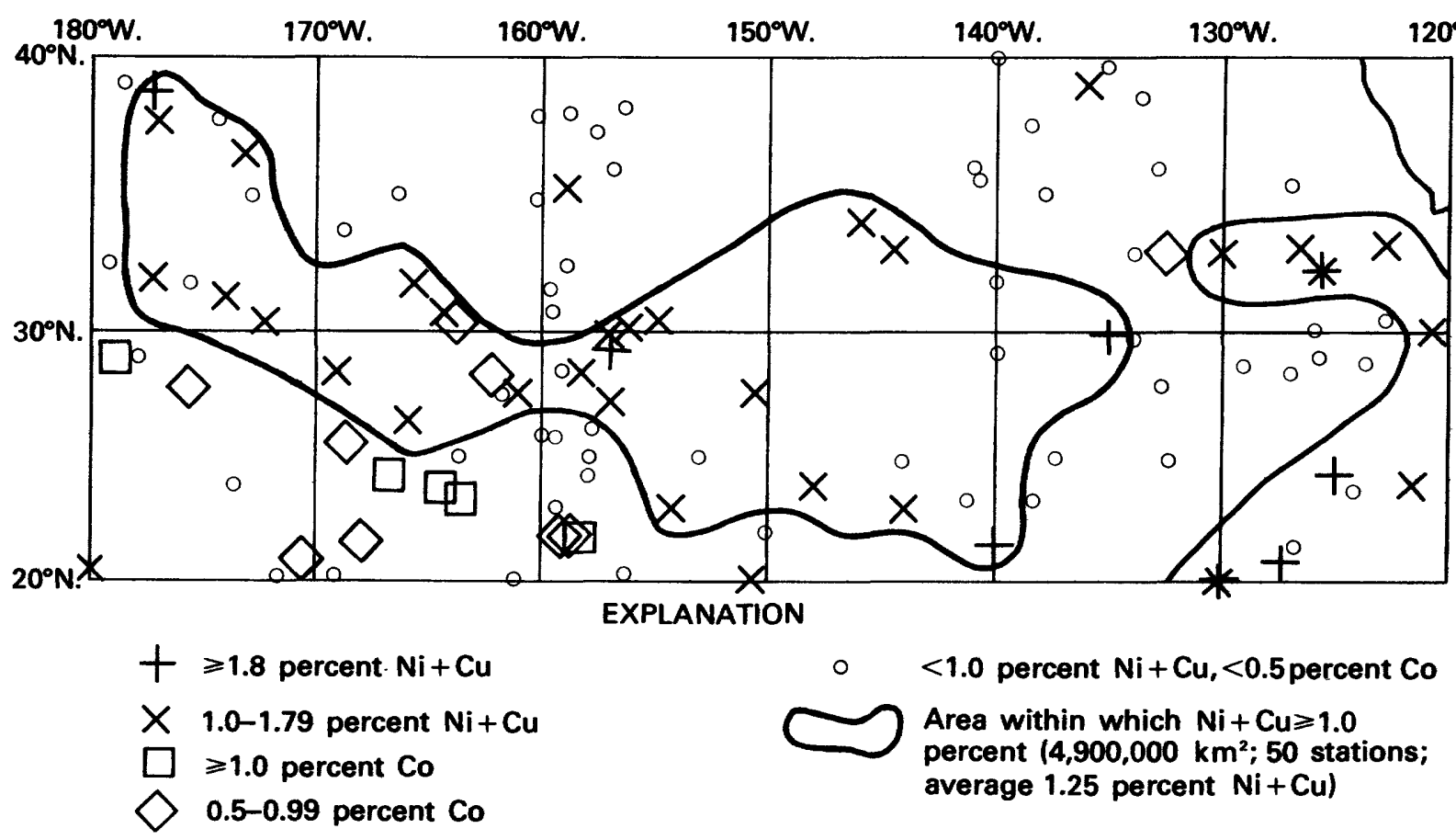

FIGURE 22. - Target areas for exploration for manganese nodules rich in combined nickel and copper in the central northeastern Pacific Ocean.

TABLE 21. - World means and ocean maximums (in percent) of several other elements in manganese nodules that have exceptionally high concentrations

$[-$, no data. Values in italies are based on fewer than 10 samples]

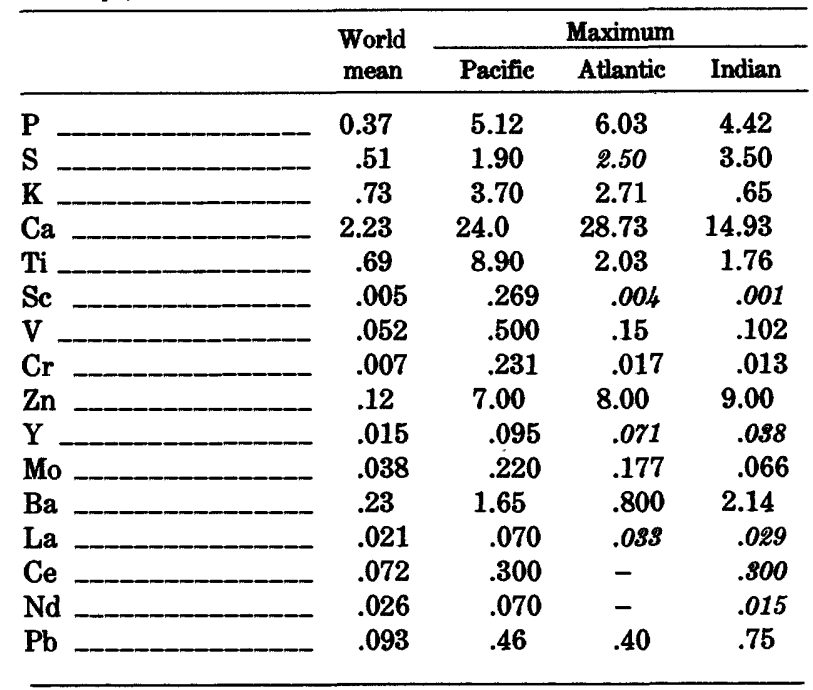

Atlantic and Indian Oceans are 2.03 and 1.76 percent, respectively. The maximum for zinc is from the Indian Ocean, but the high values in the Atlantic and Pacific Oceans are 8.0 and 7.0 percent, respectively. It seems possible, then, that types of metal-rich nodule groups other than those discussed here may exist and that some of them may have potential economic value.

The Scripps Sediment Data Bank had no analyses for platinum metals and gold in manganese nodules as of March 1980 . In 1932, V. M. Goldschmidt and C. Peters (see Goldschmidt, 1954), however, reported $0.5,0.2$ and $0.2 \mathrm{ppm}$ platinum, palladium, and rhodium, respectively, in a nodule from Challenger Station No. 286 in the southeastern Pacific (133 ${ }^{\circ} 22^{\prime}$ W., $3^{\circ} 29^{\prime}$ S.) Harriss and others (1968) determined palladium, irridium, and gold values in several nodules and found ranges of 0.24 to $9.25,0.90$ to 23.1 , and 0.21 to $8.28 \mathrm{ppb}$, respectively. Although individual analyses thus vary considerably, the average for each metal is similar for both Atlantic and Pacific nodules, and no correlation with any other major and trace metals was found.

Recently, P. J. Aruscavage (see Flanagan and Gottfried, 1980) determined platinum, palladium, and ruthenium values for the two nodule samples used by the U.S. Geological Survey as standard samples. The one from the Clarion-Clipperton zone (at $124^{\circ} 28^{\prime} \mathrm{W} ., 4^{\circ} 50^{\prime} \mathrm{N}$.) contains $123,5.6$, and 4.7 ppb of platinum, palladium, and ruthenium, respec- 


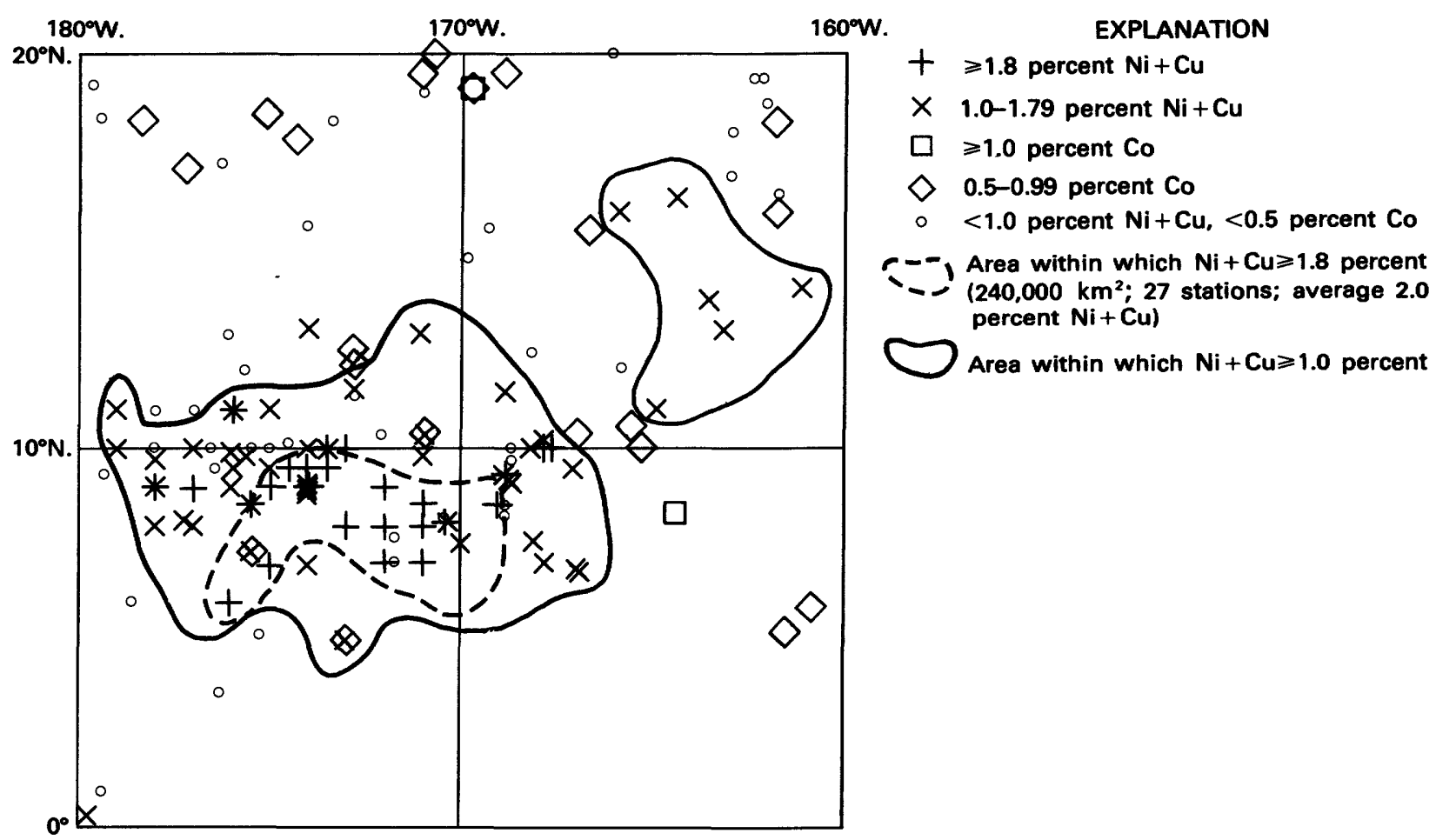

FIGURE 23. - Target areas for exploration for manganese nodules rich in combined nickel and copper in the central north equatorial Pacific Ocean.

tively, and the one from the Blake Plateau (at $78^{\circ} 22^{\prime}$ W., $31^{\circ} 02^{\prime}$ N.) contains $453,2.5$, and $18 \mathrm{ppb}$, respectively. Analyses of 12 other nodules from the western Atlantic (Manheim and others, 1980) show that iron-enriched nodules from seamounts have the lowest platinum values, the maximum being $120 \mathrm{ppb}$. Elements best correlated with platinum in these samples are nickel and cadmium. The rhodium control of these samples ranges from 2 to $30 \mathrm{ppb}$.

Because so few samples have been analyzed for precious metals, nothing can be said about their geographic or geochemical distribution. If the few data available are reliable, they do suggest that the concentrations of silver in the nodules and of the metals that are commonly associated with gold in its ores (antimony, tellurium, and bismuth) are geochemically remarkable, even though the actual amounts are small. The world means for silver, antimony, tellurium, and bismuth in the nodules (table 17) are $0.001,0.005,0.022$, and 0.002 percent, respectively, and represent concentration factors above the averages in oceanic crust (according to Lee and Yao, 1970) of 110, 55, 250,000, and 200 , respectively.
Interest in recovering metals from subsea manganese nodules has thus far focused on nickel, copper, cobalt, and (on the part of a few companies) manganese. In seems possible, however, that some other elements-molybdenum and vanadium, for example-may also prove to be recoverable as coproducts, particularly if hydrometallurgical processes are used to concentrate the metals.

\section{GENETIC IMPLICATIONS OF VARIATIONS IN COMPOSITION OF MANGANESE NODULES}

The observations made in this analysis must be explainable under any comprehensive theory of the origin of subsea manganese nodules. Before we review existing theories, it would be useful to summarize salient features that require explanation:

1. The differences in the metal contents of nodules in the different ocean basins, the high concentration of nodules rich in combined nickel and copper on the eastern sides of the ocean basins and of those rich in cobalt on the western sides of the Pacific and Indian 


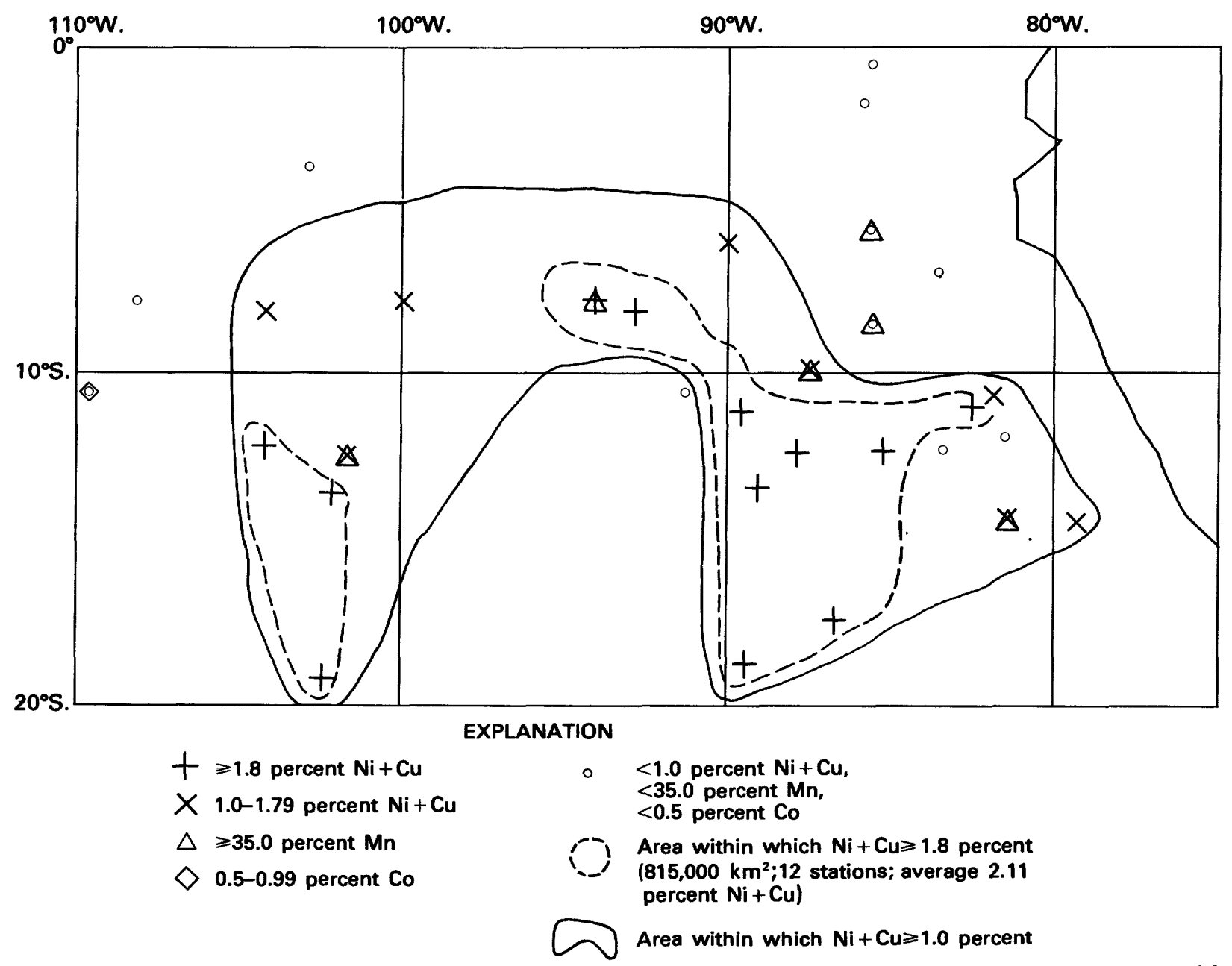

FIGURE 24. - Target areas for exploration for manganese nodules rich in combined nickel and copper in the southeastern equatorial Pacific Ocean.

Oceans, and the occurrences of nodules containing more than 35 percent manganese mainly on the eastern side of the Pacific basin and those high in iron on the western side.

2. The relation between metal content and latitude, including the concentration of nodules high in cobalt and iron between $20^{\circ}$ and $40^{\circ}$ latitude in both hemispheres.

3. The relation of nickel, copper, cobalt, and iron to water depth.

4. The relation of nodule abundance to depth.

5. The great complexity in the chemical composition of the nodules, which contain nearly 60 elements, many of which are present in concentrations many times larger than their averages in oceanic crust and several of which are present in local concentrations many times larger than their world means.
Although iron is one of the major constituents of the nodules, it is less abundant in those nodules richest in other metals, such as the nodules in the Clarion-Clipperton zone, than it is in average oceanic crust.

6. The existence of essentially nonoverlapping nodule types defined by their high contents of combined nickel and copper, cobalt, and manganese but also showing consistent differences in their contents of many other elements.

7. The high positive correlations of cobalt with iron, nickel with copper, and combined nickel and copper with manganese and with the manganese-iron ratio and the negative correlation of cobalt with nickel, copper, and manganese, except where the cobalt contents are in the highest range. 


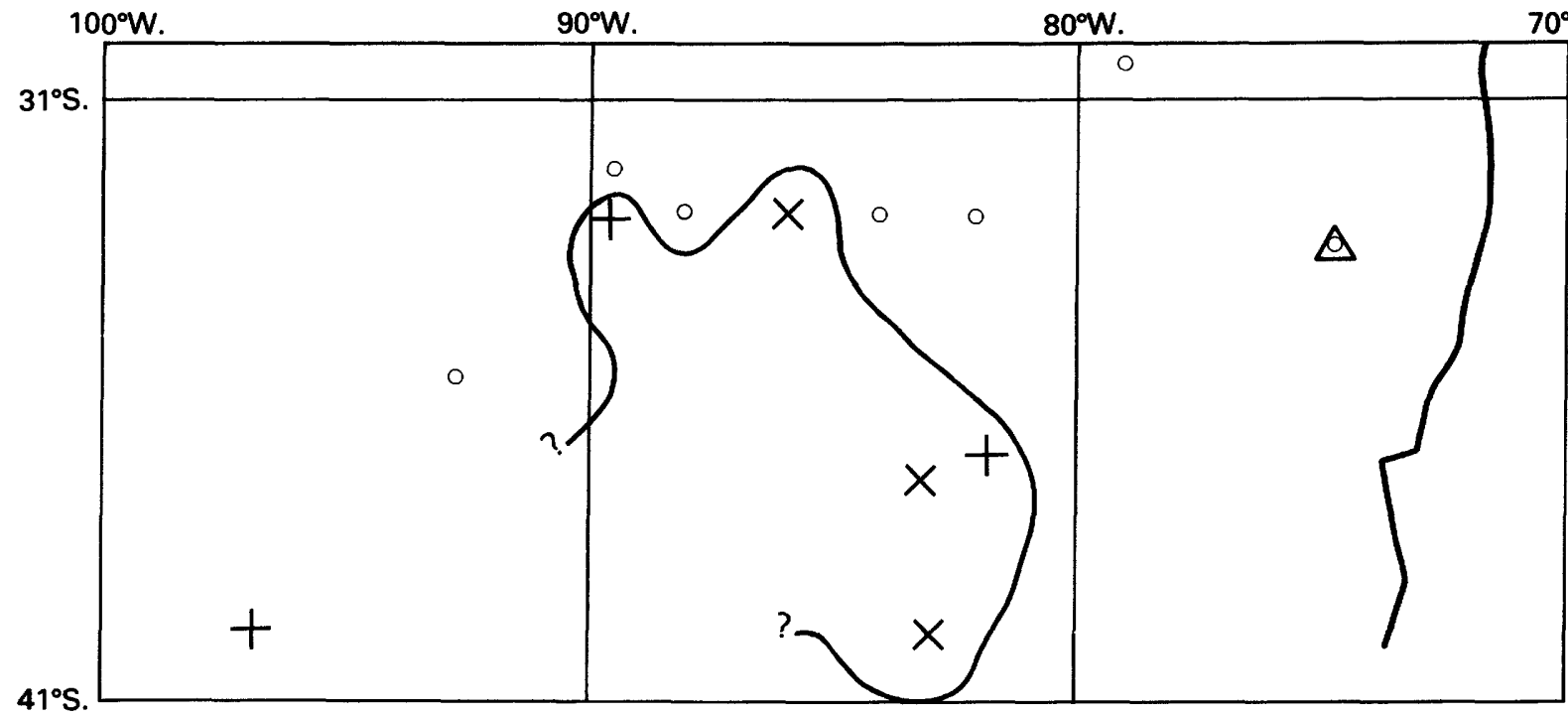

EXPLANATION

$$
\begin{array}{rl}
+ & \geqslant 1.8 \text { percent } \mathrm{Ni}+\mathrm{Cu} \\
X & 1.0-1.79 \text { percent } \mathrm{Ni}+\mathrm{Cu} \\
\triangle & \geqslant 35.0 \text { percent } \mathrm{Mn} \\
& <1.0 \text { percent } \mathrm{Ni}+\mathrm{Cu},<35.0 \text { percent } \mathrm{Mn}, \\
& <0.5 \text { percent } \mathrm{Co}
\end{array}
$$

Area within which $\mathrm{Ni}+\mathrm{Cu} \geqslant 1.0$ percent $\left(490,000 \mathrm{~km}^{2} ; 5\right.$ stations; average 1.76 percent $\mathrm{Ni}+\mathrm{Cu}$ )

FIGURE 25.- Target area for exploration for manganese nodules rich in combined nickel and copper in the central southeastern Pacific Ocean.

8. The strong inverse relation between concentration and combined nickel and copper content in nodules containing $\geq 1.0$ percent combined nickel and copper and the weak relation between concentration and grade in the ClarionClipperton zone.

\section{RELATION OF METAL CONTENT TO MINERALOGY}

Many of the variations in the chemical compositions of nodules are reflected in their mineralogies. Study of these mineralogies is difficult because most component particles are submicroscopic, but much progress has been made, beginning with the pioneering X-ray diffraction studies of Buser and Grutter (1956). They described three manganese oxide minerals in the nodules by identifying their $\mathrm{X}$-ray patterns as those of synthetic analogues and named them $10-\AA$ manganite, $7-\AA \AA$ manganite, and $\delta \mathrm{MnO}_{2}$. They also identified the ferric oxyhydroxide mineral goethite as a component of the nodules. Subsequent workers (for example, Straczek and others, 1960; Hewett and others, 1963; Manheim, 1965; Cronan and Tooms, 1969) correlated the
10- $\AA$ manganite with todorokite and the $7-\AA$ manganite with birnessite. Controversey has developed over the terminology used to describe the manganese minerals and indeed over the question of whether they are valid minerals (see Burns and Burns (1977) for a review), but there seems to be no disageement over the existence of the three phases. Most authors, following the recommendations of Burns and Burns (1977), have referred to them as todorokite, birnessite, and $\delta \mathrm{MnO}_{2}$. Chukhrov and others (1979), however, recently proposed that the $\delta \mathrm{MnO}_{2}$ phase be called vernadite. Burns and Burns (1979) accepted that proposal, and that usage is adopted here. Although goethite has been reported by some other investigators, the iron phase is generally believed to be amorphous hydrated ferric oxide (Burns and Burns, 1977; Bischoff and others, 1981).

All three of the manganese minerals may be present in individual nodules, but it appears that vernadite is present in most of them. Birnessite is less common and generally occurs only where the other two are present (Barnes, 1967; Piper and others, 1979; Bischoff and others, 1981). The vernadite phase is extremely fine grained, and, when 
$150^{\circ} \mathrm{W}$

$140^{\circ} \mathrm{W}$.

$130^{\circ} \mathrm{W}$.

$120^{\circ} \mathrm{W}$

$36^{\circ} \mathrm{S}$.
$46^{\circ} \mathrm{S}$.

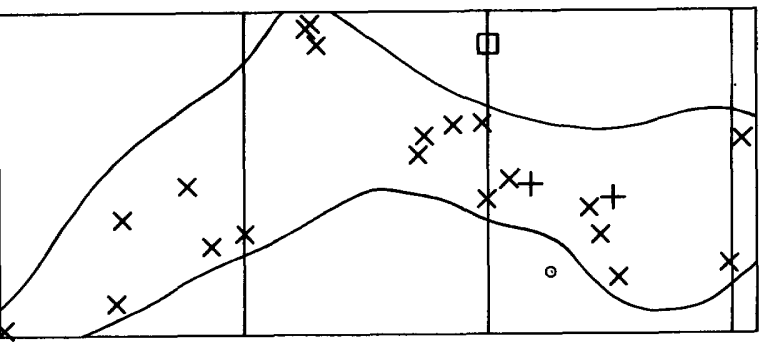

\section{EXPLANATION}

$+\quad \geqslant 1.8$ percent $\mathrm{Ni}+\mathrm{Cu}$

$\times \quad$ 1.0-1.79 percent $\mathrm{Ni}+\mathrm{Cu}$

$\geqslant 1.0$ percent Co

$<1.0$ percent $\mathrm{Ni}+\mathrm{Cu},<0.5$ percent $\mathrm{Co}$, $<35.0$ percent $\mathrm{Mn}$

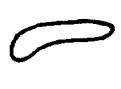

Area within which $\mathrm{Ni}+\mathrm{Cu} \geqslant 1.0$ percent $\left(1,300,000 \mathrm{~km}^{2} ; 21\right.$ stations; average 1.4 percent $\mathrm{Ni}+\mathrm{Cu}$ )

FIGURE 26. - Target area for exploration for manganese nodules rich in combined nickel and copper in the central South Pacific Ocean.

it occurs in nodules, it contains admixed amorphous iron hydroxide and extremely fine grained silicate minerals (Usui, 1979; Halbach and Ozkara, 1979), including some of extraneous origin. Recently, Bischoff and others (1981) have shown that the mineral phillipsite $-(\mathrm{K}, \mathrm{Na}, \mathrm{Ca})_{1-2}(\mathrm{Si}$, $\mathrm{Al})_{8} \mathrm{O}_{16} \cdot \mathrm{H}_{2} \mathrm{O}$, according to Fleishcher $(1980)$-is also ubiquitous in the nodules, forming in place on the growing nodules, as the manganese minerals and amorphous iron hydroxide do. They suggested, in fact, coupled and mutually catalytic reactions in which the alteration of phillipsite from volcanic glass locally raises the $\mathrm{pH}$ and stimulates the oxidation of $\mathrm{Mn}^{+2}$, which, in turn, releases the hydrogen required in the formation of phillipsite.

Abundant evidence has accumulated to show that variations in the contents of these minerals are reflected in variations in bulk nodule chemical composition. Todorokite- $\left(\mathrm{Mn}^{+2}, \mathrm{Ca}\right.$, $\mathrm{Mg}) \mathrm{Mn}^{+4} \mathrm{O}_{7} \cdot \mathrm{H}_{2} \mathrm{O}$ ), according to Fleischer (1980) - has a structure that includes sites in which small divalent cations, such as nickel, copper, magnesium, and zinc, can replace $\mathrm{Mn}^{+2}$ and other sites that will accommodate large cations such as potassium. Birnessite- $\mathrm{Na}_{4} \mathrm{Mn}_{14} \mathrm{O}_{27} \cdot \mathrm{H}_{2} \mathrm{O}$, according to Fleischer (1980)-apparently has somewhat similar properties (Burns and Burns, 1977). It is the nodules rich in todorokite and birnessite that are rich in nickel and copper and the other minor metals previously described as most abundant in the $\geq 1$-percent combined nickel and copper type (Burns and Fuerstenau, 1966; Barnes, 1967; Cronan and Tooms, 1969; Tooms and others, 1969; Margolis and Burns, 1976; Piper and Williamson, 1977; Calvert and Price, 1977; Halbach and Ozkara, 1979; Usui, 1979; Piper and others, 1979; Cronan, 1980; Bischoff and others, 1981). It is also the todorokite-rich nodules that have a manganeseiron ratio of >1.5 (Margolis and Burns, 1976;
Piper and Williamson, 1977; Calvert and Price, 1977; Halbach and Ozkara, 1979). On the basis of microprobe analyses of individual layers of todorokite and the $\delta \mathrm{MnO}_{2}$ phase (including the amorphous iron) in nodules from the north-central Pacific, Usui (1979) found several of the elements that he examined partitioned between the two phases by grade such that concentrations of manganese greater than 30 percent, of both copper and nickel greater than 0.8 percent, of magnesium greater than 0.8 percent, of potassium greater than 0.6 percent, and of sodium greater than 0.5 percent are in the todorokite phase, and concentrations below those values are mostly, if not entirely, found in the vernadite phase. Amounts of iron greater than 4 percent and of silica greater than 1.2 percent are restricted to the $\delta \mathrm{MnO}_{2}$ (vernadite) phase. Cobalt has about the same range in both phases, but most of the concentrations greater than 0.3 percent are in the $\delta \mathrm{MnO}_{2}$ phase, and most below that value are in todorokite. Although a number of authors have reported a positive correlation between cobalt and iron, Usui found a positive correlation of cobalt with manganese and concluded that trivalent cobalt is substituting for manganese in the vernadite phase and that some divalent cobalt may substitute for manganese in the todorokite phase (10- $\AA$ manganite in his terminology). Burns (1976) made a similar proposal and suggested that the formula for $\delta \mathrm{MnO}_{2}$ (vernadite) should be $\left(\mathrm{Mn}, \mathrm{Co}^{+3}\right) \mathrm{Mn}_{6} \mathrm{O}_{13} \cdot x \mathrm{H}_{2} \mathrm{O}$. Halbach and Ozkara (1979) reported similar findings in studies of nodules from an area within the ClarionClipperton zone. Nodules consisting mainly of todorokite contain 23 to 32 percent manganese, 2 to 3.2 percent combined nickel and copper, 0.1 to 0.2 percent cobalt, and less than 7 percent iron; those consisting mainly of vernadite contain 16 to 24 percent manganese, 1.0 to 1.6 percent combined 
$70^{\circ} \mathrm{E}$.

$80^{\circ} \mathrm{E}$.

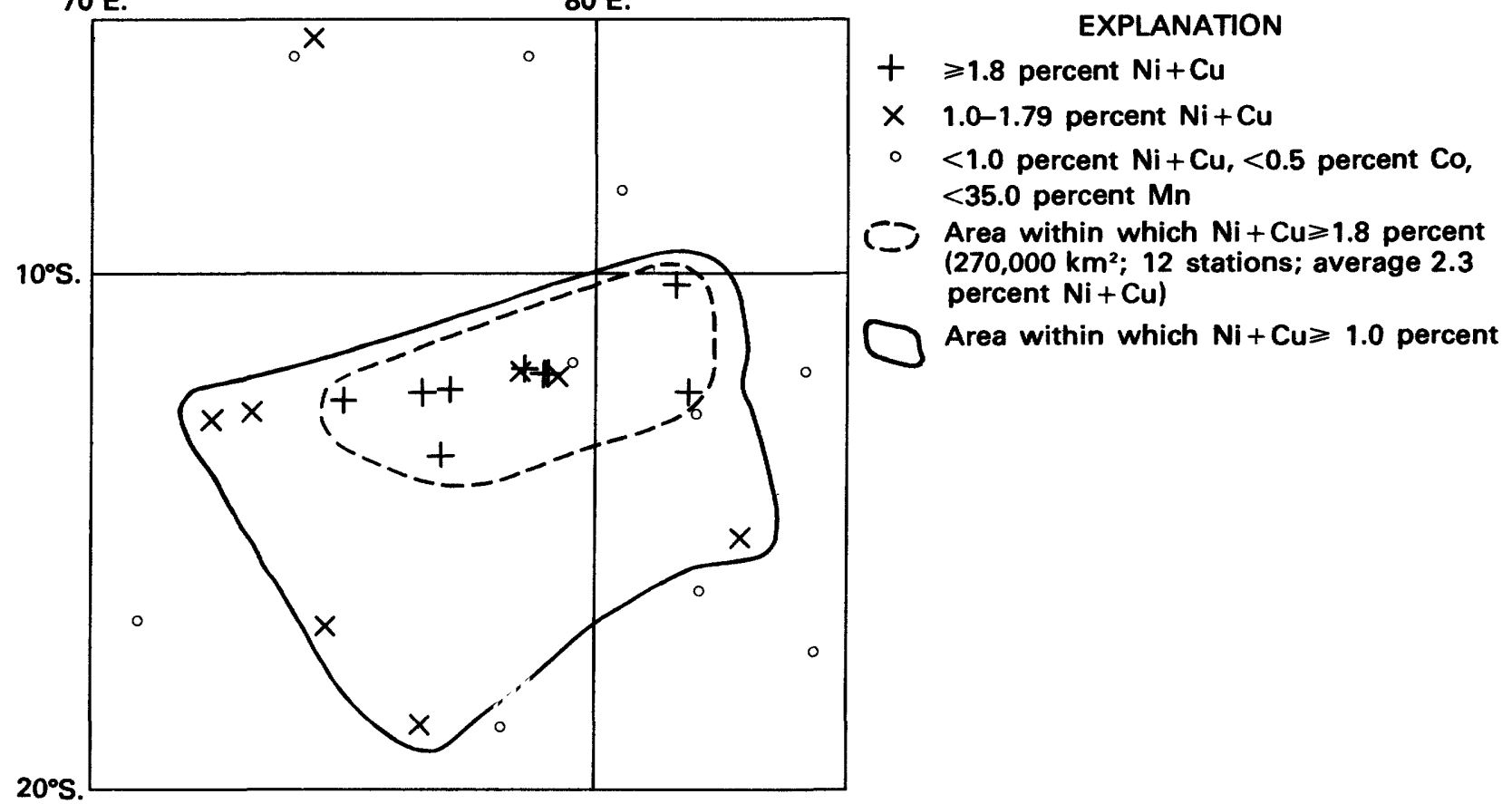

FIGURE 27. - Target areas for exploration for manganese nodules rich in combined nickel and copper in the central south equatorial Indian Ocean.

nickel and copper, 0.25 to 0.40 percent cobalt, more than 1 percent titanium dioxide, and more than 9 percent iron and have a manganese-iron ratio of 2.5 or less.

Bischoff and others (1981) believed that titanium, phosphorus, and some silica are associated with the amorphous iron phase, and Calvert and Price (1977) showed a similar correlation of arsenic, yttrium, lead, strontium, and cobalt with iron. Even though the amorphous iron hydroxide is physically a part of the vernadite phase in the nodules, its content varies independent of the vernadite content. Variations in the chemistries of the nodules are thus best understood as variations in their contents of authigenic todorokite-birnessite, vernadite, amorphous iron hydroxide, and phillipsite, along with clay and other siliceous minerals of extraneous origin. To illustrate compositional variations in the authigenic components of nodules, Bischoff and others (1981) used a ternary diagram in which all of the manganese phases are lumped together and plotted against the phillipsite and amorphous iron phases. Figure 29 follows this design and shows an almost complete gradation of mineral composition within the ranges of about 4 to 55 percent manganese oxide phases, 7 to 37 percent amor- phous iron phase, and 7 to 60 percent phillipsite phase.

Given the mineralogy of the nodules, it is easy to understand the concentration of so many of the chemical elements. Not only does the structure of todorokite favor the incorporation of many elements, but also both iron and manganese oxides are well known for their abilities to scavenge other metals from seawater by physical adsorption (Goldberg, 1954). It is also easy to understand variation in metal content as a function of mineralogy, at least in large part. But to what factors do variations in the proportion of mineral phases relate?

\section{RELATION TO WATER DEPTH}

Barnes (1967), Cronan (1967), Cronan and Tooms (1969), and Piper (1972) found that the relation between metal content and depth is also a function of the mineralogy of the nodules, todorokite being more abundant in deeper water nodules and vernadite being dominant in nodules from shallower depths. The three manganese oxide phases represent different degrees of oxidation of manganese, and Cronan and Tooms (1969) concluded that variations in the mineralogy of nodules 
$95^{\circ} \mathrm{E}$.

$105^{\circ} \mathrm{E}$.

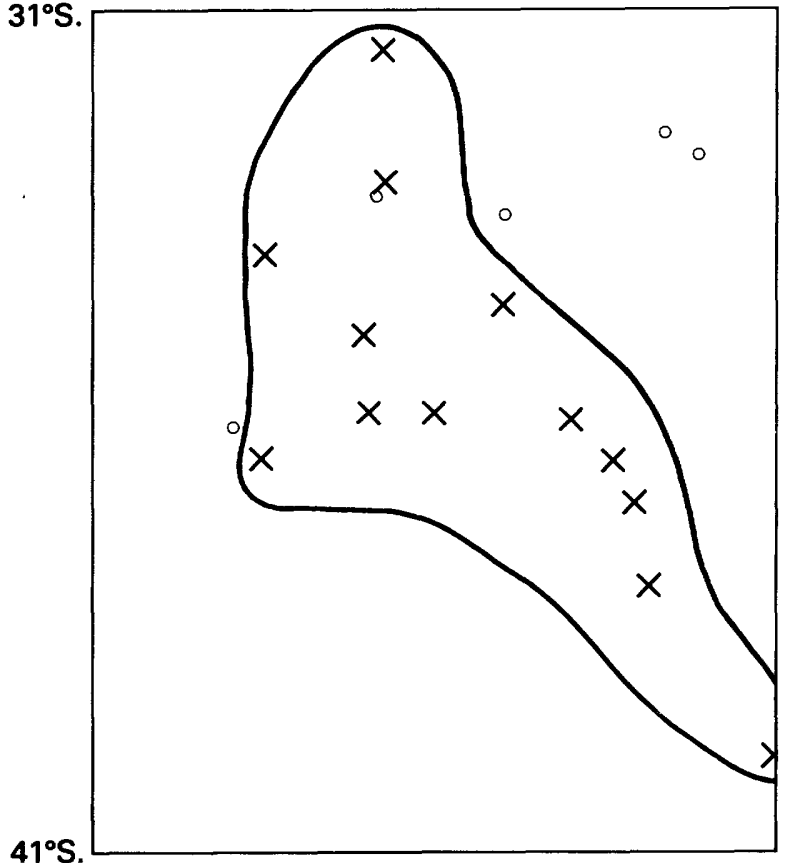

EXPLANATION

$$
\begin{aligned}
& \times 1.0-1.79 \text { percent } \mathrm{Ni}+\mathrm{Cu} \\
& \circ \quad<1.0 \text { percent } \mathrm{Ni}+\mathrm{Cu},<0.5 \text { percent } \mathrm{Co} \text {, } \\
& <35 \text { percent } \mathrm{Mn} \\
& \text { Area within which } \mathrm{Ni}+\mathrm{Cu} \geqslant 1.0 \text { percent } \\
& \left(300,000 \mathrm{~km}^{2} ; 15\right. \text { stations; average } \\
& 1.35 \text { percent } \mathrm{Ni}+\mathrm{Cu})
\end{aligned}
$$

FIGURE 28. - Target area for exploration for manganese nodules rich in combined nickel and copper in the southeastern Indian Ocean.

with depth may reflect variations in the degree of oxidation of the environment of deposition. Piper and Williamson (1977) found support for this theory in the fact that the few nodules containing more than 0.5 percent cobalt that occur in water depths greater than $3,000 \mathrm{~m}$ are from the area immediately to the west of the Line Island Ridge, where there is a major intrusion of highly oxidizing Antarctic bottom water.

Cronan (1980) related the increase in the combined nickel and copper content of nodules that takes place at a depth of about $3,000 \mathrm{~m}$ to the lysocline - the depth at which calcium carbonate in organic remains begins to dissolve and to liberate metals, particularly copper, concentrated by organisms. Because copper is more concentrated in the skeletons of many organisms than nickel is (Halbach and others, 1979), this process would also explain the fact that copper-nickel ratios in shallow-water nodules are lower than those in deepwater nodules. (See Heath (1981) for a review of the importance of surface plankton in the concentration of metals.)

\section{EFFECTS OF DIRECT PRECIPITATION FROM SEAWATER IN COMPARISON WITH DIAGENETIC PRECIPITATION}

Another factor that may explain differences in nodule mineralogy involves the source and manner of deposition of their components. Rabb (1972) found that many nodules have a smooth upper surface and a gritty, lumpy bottom. Separate analyses of tops and bottoms showed that the tops are high in iron, cobalt, and lead and low in copper, nickel, molybdenum, zinc, and manganese and that the reverse is true for the bottoms. Calvert and Price (1977), Halbach and Fellerer (1980), Piper and others (1979), and Usui (1979) have suggested that the upper surfaces of such nodules (shown to be composed of vernadite) represent precipitate derived directly from seawater and that the bottoms (todorokite) represent a diagenetic precipitate by leaching of the underlying sediment. Concentrations of manganese, copper, nickel, cobalt, and zinc in the interstitial water of deep-sea sediments have been found to be higher than those in deep seawater, and Lynn and Bonatti (1965) and others (Bender, 1971; Renard and others, 1976) proposed that $\mathrm{Mn}^{+4}$ in the sediments is reduced to $\mathrm{Mn}^{+2}$ under low $\mathrm{Eh}$ conditions (perhaps created in part by the oxidation of buried organic matter, as Price and Calvert (1970) suggested), dissolved, carried upward, and precipitated under the oxidizing conditions prevailing at or near the surface. Nickel and copper also go into solution in this process (Piper and others, 1979). In the redox potential range in the sediment, the solubility of iron oxide is not affected, and it remains in the sediment (Borchert, 1970, referred to by Halbach and Ozkara, 1979; Cheney and Vredenburgh, 1968, referred to by Usui, 1979). The sediment thus represents the residue resulting from diagenesis (Piper and others, 1979).

Some nodules (Halbach and Ozkara's (1979) type A and Usui's (1979) type B) contain little or no vernadite and are explained as having formed within the sediment just beneath the surface. Halbach and Ozkara also found nodules (their type B) composed entirely of vernadite on the flanks of a seamount within the area that they studied. They found that, in contrast to the todorokite nodules, in which the 


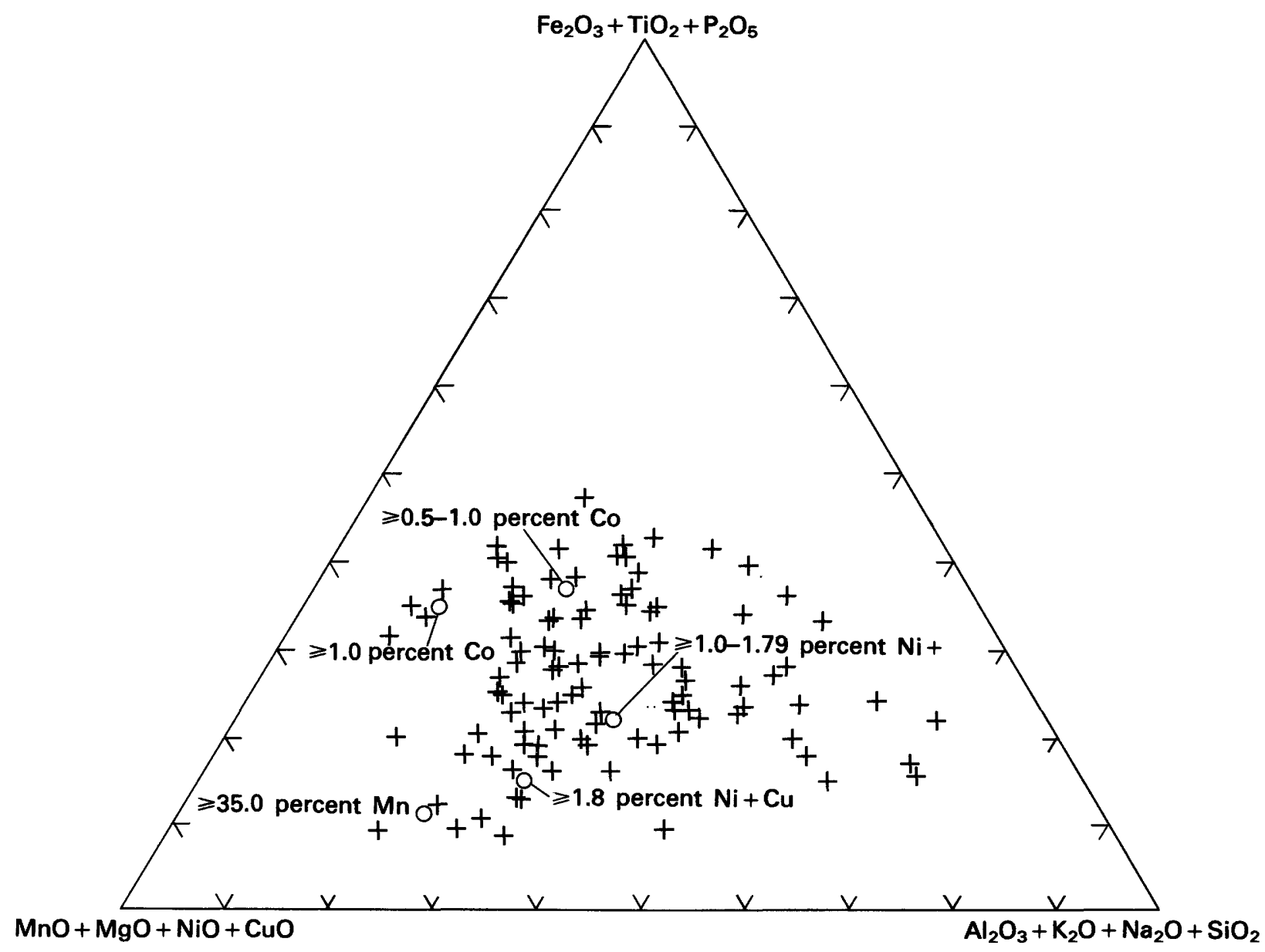

FIGURE 29. - Ternary plot of the principal mineral phases (normalized to total 100 percent) of manganese nodules at the 107 stations in the Scripps Institution of Oceanography's Sediment Data Bank for which analyses of all the constituents shown have been made. Compositions shown for the metal types are based on means.

nucleus is generally a fragment of a preexisting nodule, the vernadite nodules generally have a rock nucleus. They translate the findings of Heye and Marchig (1977)-that nodule growth rate increases with increasing manganese, nickel, and copper contents-to conclude that the growth rates of todorokite nodules and layers are 10 to 15 times greater those of vernadite (see also Piper and Williamson, 1977), which they and Usui believed is deposited from a colloidal form in nearbottom seawater rather than from an ionic solution of $\mathrm{Mn}^{+2}$, as todorokite is.

M. Lyle (unpublished 1978 thesis, referred to by Heath, 1981), confirming Heye and Marchig's (1977) finding, observed an inverse ratio between nodule growth and iron content and suggested that, in areas of very low productivity, growth is slow and is controlled by precipitation from seawater. In areas of oxic diagenesis, the rate of growth increases with increasing biologic productivity in surface water. "As the rate of input of organic debris increases to the level at which anoxic diagenesis begins... the mobilization of $\mathrm{Mn}$ under anoxic conditions results in rapid nodule growth that virtually swamps the input of other metals, leading to lower $\mathrm{Cu}$ and $\mathrm{Ni}$ contents" (Heath, 1981, p. 757). This process, Heath believed, explains the high manganese content of the nodules in the hemipelagic sediment along the eastern margin of the Pacific.

The three types of nodules described by Halbach and Ozkara are all from within a relatively small area in which the water depths range from $4,600 \mathrm{~m}$ at the summit of a seamount to $5,200 \mathrm{~m}$ on the surrounding ocean floor. The presence of both todorokite and vernadite in the same nodules in- 
dicates that both minerals may form in the same macroenvironment. Halbach and Ozkara believed that the type formed is governed by topography, the availablity of rock fragments to serve as nuclei, local sedimentation rate, and bottom-current activity; vernadite forms as nodules or as crusts on rock surfaces where no sediment has accumulated or on the tops of nodules exposed to seawater, and todorokite forms at or near the surface of the sediment, which is largely radiolarian ooze in the southern part of the Clarion-Clipperton zone and red clay in the northernmost part. Nodules containing adjacent laminae of both minerals (the A type of Usui and the $\mathrm{AB}$ type of Halbach and Ozkara) reflect merely a change in the nodule's exposure to seawater-for example, burial by sediment to deposit todorokite on top of vernadite or a winnowing away of enough sediments to uncover a nodule forming near the bottom surface. Local variations in nodule content within the ClarionClipperton zone-in which the todorokitevernadite nodules are most common (Halbach and Ozkara, 1969)-may thus reflect differences in the todorkite contents of the nodules as a result of local variations in their exposure to seawater. Cronan (1977), however, pointed out that, although the presence of todorokite is a probable prerequisite for the enrichment of nickel and copper in the nodules, it is not the only factor, for some todorokite-rich nodules outside the North Pacific have lower contents of these metals.

The great concentration of manganese with respect to iron in Clarion-Clipperton zone nodules is thus explained as a diagenetic mobilization of manganese in sediments in which the iron, although it is several to many times more abundant than manganese, remains fixed. More puzzling is the fact that, in the vernadite-amorphous iron phase apparently formed by colloidal precipitation from seawater, the manganese-iron ratio, although averaging only about 1.5 according to Usui's analyses, is the reverse of what it is in seawater. For whatever reason, proportionately more iron than manganese leaves seawater in some other way.

This fact leads to other interesting questions: why do the iron and manganese phases occur together, and why do they commonly occur as nodules? As Halbach and Ozkara (1979) and others indicated, they oecur as encrustations on bedrock where nucleating grains are absent. The tendency for extremely fine grained particles to form ag- gregates is common in many other kinds of materials; Ramberg (1952) attributed this tendency to differences in surface energy that lead to a lower free energy in clusters rather than in disseminated form. The scarcity of ironmanganese minerals indicates that iron and manganese have little chemical affinity, but Burns and Burns (1977, p. 246) pointed out that, "although $\mathrm{MnO}_{2}$ and $\mathrm{Fe} \mathrm{OOH} \cdot x \mathrm{H}_{2} \mathrm{O}$ consist of very small disordered crystallites, both phases contain cations in octahedral sites of hexagonally close-packed oxygen layers. Therefore, these two phases in manganese nodules are highly susceptible to epitaxial intergrowth [that is, oriented intergrowth of one phase on the other where lattice parameters or interplanar spacings are similar] which probably initiates nucleation and leads to the intimate association of manganese and iron oxide phases." As mentioned earlier, Bischoff and others (1981) thought that the other main constituent of manganese nodules, phillipsite, may form as a coupled reaction with the manganese oxides. It thus appears that there are good reasons for these chemically distinct phases to occur together in the nodules.

Because both todorokite and vernadite phases may form in the same macroenvironment, it would seem that, of the factors previously proposed as affecting the composition of the nodules, hydrostatic pressure (Barnes, 1967), dissolved oxygen (Cronan and Tooms, 1969), and $\mathrm{pH}-\mathrm{Eh}$ conditions within the abyssal aqueous environments (Crerar and Barnes, 1974) do not control the deposition of todorokite versus vernadite or the ratio between the two. Such physicochemical factors, however, may influence their contents of minor elements. The enrichment in the cobalt contents of nodules from shallow depths, for example, has been ascribed to oxidation from $\mathrm{Co}^{+2}$ to $\mathrm{Co}^{+3}$ under the highly oxidizing conditions prevailing on seamounts and similar features (Goldberg, 1961; Burns, 1965; Cronan and Tooms, 1969; Piper and Williamson, 1977), and Goldberg (1965) suggested a similar effect with respect to lead. The wide variations in the nickel and copper contents of todorokite (Usui, 1979) may be due in part to variations in physicochemical factors.

\section{RELATION TO REGIONAL VARIATIONS IN SEDIMENT TYPE, BIOLOGIC PRODUCTIVITY, AND PHYSIOGRAPHY}

Because of the importance of sediment diagenesis in the formation of todorokite, which 
has a high manganese-iron ratio and generally high nickel and copper contents, regional variations in sediment character should be examined as a possible source of regional variations in nodule composition. Piper and Willilamson (1977) found that, in the Pacific, the relation between the manganeseiron ratio of nodules and latitude is almost the reverse of the relation between the manganeseiron ratio of sediments and latitude (sediment data from Skornyakova (1965)). In nodules, manganeseiron ratios are in the range of 6 to 9 near $10^{\circ} \mathrm{N}$. and $10^{\circ} \mathrm{S}$. and diminish to about 2 in the equatorial region and to less than 1 north and south of the $20^{\circ}$ parallels. In sediments, the high manganese-iron ratio is about 0.7 in the equatorial region, and the lows of 0.01 to 0.03 are in the $10^{\circ} \mathrm{N}$. and $10^{\circ} \mathrm{S}$. regions. On the basis of a comparison with Lisitzin's (1972) map showing sedimentation rates for the Pacific, Piper and Williamson suggested that nodules having high manganese-iron ratios tend to occur in areas where sediment accumulation is slow.

Although Skornyakova (1979) found no correlation between the manganese, nickel, copper, and cobalt contents of nodules and associated sediment, she broadly related changes in nodule composition to sediment lithology. In the northern Pacific, for example, she observed that nodules having the highest average manganese, nickel, copper, and zinc concentrations are associated with the radiolarian ooze of the equatorial belt and decrease successively in the adjacent zones of the miopelagic clay, eupelagic clay, and calcareous ooze. She attributed the differences in the iron and manganese contents of nodules on the eastern and western sides of the Pacific to differences in primary manganese contents during sedimentation; sediments on the west are initially poor in manganese and those on the east are richer because of the presence of only a thin oxidized layer of sediment. She related the composition of nodules in the equatorial belt to the high organic productivity associated with the equatorial currents, which cause the diagenetic migration of the metals as buried organic matter oxidizes, and to slow deposition of sediment because of highvelocity bottom currents. Heath (1981) also related the metal content of the nodules to sediment type and, in turn, to biologic productivity in the overlying waters.

The zone of highest organic productivity in the equatorial region of the Pacific lies 50 to $100 \mathrm{~km}$ south of, rather than above, the zones in which nodules are richest in nickel and copper. Exon (1981, p. 61) suggested that this zone is a result of northwestward movement of the Pacific plate in this region at a rate of about $100 \mathrm{~km} / \mathrm{m}$.y.: "Assuming that the high productivity zone has not moved much (relative to the equator) in the past 10 million years, the time during which the nodules probably formed, they would have been beneath the high productivity zone for much of their growth."

Several other investigators (Arrhenius, 1963; Greenslate and others, 1973; Margolis and Burns, 1976; Piper and Williamson, 1977; Cronan, 1977) also have suggested that organic productivity plays an important role in concentrating some of the nodule metals and transporting them to the bottom and, when such metals are buried by sediment, in creating the reducing environment that lead to their diagenetic mobilization and subsequent deposition at the surface. According to Glasby (1981, p. 4), "On a regional scale, the most important factor controlling the composition of South Pacific abyssal nodules is the biological productivity of the overlying surface sea water." Nodule abundance in that area, he reported, is inversely related to sedimentation rate-a factor. that Piper and others (1982) considered to be of primary importance in the distribution of nodules over the Pacific basin as a whole (see also Menard, 1976).

Greenslate (1975), Wendt (1974), and Margolis and Burns (1976) reported the widespread presence of sessile arenaceous foraminifera on the nodules. Margolis and Burns found that, whereas foraminifera are present on nodules from all latitudes, they are most abundant and most diverse on nodules from the Clarion-Clipperton zone. The iron, titanium, and cobalt contents of foraminiferal tubes are higher than those of the nodule surface on which they are growing, and the manganese, nickel, and copper contents are lower. Margolis and Burns did not believe that the foraminifera actually precipitate manganese, copper, and nickel, although they deposit iron oxide as a cementing agent, but they did "feel that the large number of these animals ... on the nodules from the coppernickel rich zones of the northeastern equatorial Pacific, are somehow linked to the unique chemical composition of nodules from this area" (Margolis and Burns, 1976, p. 259), perhaps as a part of the high biologic productivity of the area. They asked, however, why, if high productivity of the surface 
layers of the ocean is the critical factor in tracemetal concentration in the manganese nodules, are nodules from other areas of oceanic upwelling and high productivity (the diatom ooze beneath the Antarctic convergence at about $55^{\circ} \mathrm{S}$., for example), not also so enriched? As a possible reason, they suggested dilution by terrigenous sediment in those areas. Nodules from high southern latitudes differ from those in the equatorial region not only in their lower metal content but also in their low manganese-iron ratios. Cronan (1977, p. 37) suggested that high detrital sedimentation rates "could lead to low $\mathrm{Mn} / \mathrm{Fe}$ ratios in view of the greater amounts of releasable $\mathrm{Fe}$ relative to $\mathrm{Mn}$ in the products of continental weathering," and he suggested that higher detrital sedimentation rates in the Atlantic compared to the Pacific may explain the differences in their manganese-iron ratios.

However, many of the stations outside the Clarion-Clipperton zone in the Pacific, where nodules are high in combined nickel and copper (figure 14), as well as many stations where the nodules contain 35 percent manganese or more (figure 18) do, in fact, lie seaward of areas of coastal upwelling along the eastern side of the Pacific basin, close enough, perhaps, to receive some of the organic debris generated by coastal upwelling. But such a relationship is not evident in the central South Pacific, where the nodules are also high in combined nickel and copper (figs. 14 and 15).

Many of the regional variations in nodule metal content relate to the physiography of the ocean basins as it controls depth, organic productivity, and sediment type. Cronan's (1977) analysis of variations in nodule metal contents from different environments brings out, for example, the high cobalt content of nodules from seamounts and other submarine elevations, the high manganese content of nodules from continental borderlines, and the high combined nickel and copper contents of abyssal nodules.

In summary, many factors may play a part in the origin of subsea manganese nodules and the variations in their compositions: (1) the rate of deposition of sediment and its content of terrigenous and biogenous matter, (2) the redox potential of the environment and the extent to which diagenetic processes are locally operative, (3) the local availability of various metals, (4) the local availability of nucleating materials, (5) the bottom topography and water depth and the bottom-current activity and character, and (6) the biologic productivity of surface waters, which is, in turn, related to oceanic circulation and its effects in locally bringing nutrient-rich waters into the photic zone.

Combinations of these factors seem to explain, at least partly, some of the features of nodule distribution and composition. For example, the high concentrations of cobalt in western Pacific nodules relate to the highly oxidizing, essentially nondepositional environment prevailing on the extensive seamounts and plateaus in that area. The asymmetrical concentrations of the principal metals in nodules on the eastern sides of the oceans versus those on the western sides and their latitudinal variations may be a function of slow sedimentation at abyssal depths and oceanic circulation. The main elements of oceanic circulation are (1) two large circulating gyrals, one in the northern hemisphere moving clockwise and one in the southern hemisphere moving counterclockwise, (2) an eastward-flowing equatorial countercurrent between them, and (3) areas of high organic productivity where cold, nutrient-rich waters upwell in coastal areas along the eastern sides of the basins in each hemisphere and along the equatorial countercurrent. These elements combine to create a widespread blanket of sediments on the abyssal floor; this blanket varies regionally in character, depending on whether biogenous, pelagic, or terrigenous sediments are dominant, and is generally below the lysocline where metals are liberated from organic matter and where diagenic processes are active in mobilizing and partitioning metals.

The differences in the average compositions of nodules from ocean to ocean may reflect the major differences in their geology and morphology. The Atlantic Ocean, for example, receives much more terrigenous matter per unit of area than the Pacific, its abyssal plains and areas covered by noncalcareous pelagic sediments are proportionally much smaller, and its mean depth is nearly $\mathbf{1 0}$ percent less-all factors that would help to account for the lower average contents of manganese, nickel, and copper in Atlantic nodules.

But such broad controls are not much help in explaining many aspects of the regional trends-for example, the continuation of the poleward decrease in manganese, nickel, and copper contents of nodules to high latitudes, even in areas of high organic productivity; the area of the central South Pacific in which the content of these metals is high; the apparent localization of the manganese-rich (35 
percent or more) nodules on the eastern side of the Pacific basin and the northeastern equatorial region east of the Clarion-Clipperton zone and their lower nickel and copper contents; the higher iron content of nodules on the western side of the Pacific; and the anomalously high local content of some normally minor metals such as tellurium, lead, and zinc. Given the large number of factors that may affect the composition of the nodules, it is not surprising that it is difficult to determine their interplay in accounting for specific variations. But, plainly, a greater understanding of ocean processes and regional oceanography is needed to explain all the variations observed in the compositions of subsea manganese nodules. If the reasons for these variations do come to be understood, they may facilitate, on one hand, prospecting for economically valuable deposits; on the other hand, the local composition of nodules may serve as an indicator of locally prevailing environmental conditions.

\section{SUMMARY}

Analysis of the publicly available data in the Scripps Sediment Data Bank supports and extends previous observations concerning the composition of subsea manganese nodules. Although all nodules contain amorphous iron oxide, one or more manganese minerals, and phillipsite-all of which form by accretion around a nucleus-and some admixed silicate grains from extraneous sources, regional variations in composition are pronounced. Nodules from the Pacific average 1.42 times as much manganese and 2.36 times as much combined nickel and copper as those from the Atlantic and $\mathbf{1 . 2}$ times as much manganese and $\mathbf{1 . 5}$ times as much combined nickel and copper as those from the Indian Ocean. The mean iron content of Atlantic nodules is about 1.2 times that of Indian nodules and nearly 1.5 times that of Pacific nodules. Within each of the oceans, the composition shows both a circumferential and a latitudinal variation. Nodules richest in manganese, nickel, and copper are found mainly in the eastern parts, and those richest in iron and cobalt are found in the western parts. The average manganese, nickel, and copper contents of nodules within the $20^{\circ}$ latitudinal zones generally increase toward the equator in both hemispheres, and iron generally decreases, although its high is in the $20^{\circ}$ to $40^{\circ} \mathrm{S}$. zone. Cobalt decreases slightly toward the equatorial region in the northern hemisphere but shows the opposite relation in the southern hemisphere.

Nodule composition is also related to water depth. The relation is not linear but is more in the nature of a threshold depth of about 2,900 to 3,000 $\mathrm{m}$, above which combined nickel and copper contents greater than 1 percent are rare and below which nodules containing cobalt in amounts greater than about 0.6 percent are rare. Below the threshold depth for combined nickel and copper and above that for cobalt, the maximum metal contents increase to an optimum depth (in the Pacific, about 4,800 to $5,200 \mathrm{~m}$ for combined nickel and copper and 800 to $1,850 \mathrm{~m}$ for cobalt) and then decline. The manganese content shows little correlation with depth, although there does appear to be a decrease in the maximum and perhaps an increase in the minimum with increasing depth. Publicly available data on concentration are too sparse to support generalizations about its variations, but nearly all measurements showing nodules in concentrations of more than about 13 $\mathrm{kg} / \mathrm{m}^{2}$ are from depths of greater than about 3,700 $\mathrm{m}$. The greatest concentrations of metalliferous oxides, however, appear to be not in the nodules but in the widespread encrustations on the midPacific seamounts at depths of 1,200 to $2,500 \mathrm{~m}$.

Although the composition of the nodules varies widely, three rarely overlapping, distinct compositional types that are of possible economic interest can be recognized. (1) Nodules containing more than about 1.0 percent combined nickel and copper only expectionally contain more than 0.5 percent cobalt and 35 percent manganese. (2) Nodules containing more than 0.5 percent cobalt rarely contain more than 1.0 percent combined nickel and copper. (3) Nodules containing more than 35 percent manganese only exceptionally contain more than 0.5 percent cobalt, although they average nearly 1.1 percent combined nickel and copper. Geographically, nodules in these compositional groups occur in the regions where they might be expected on the basis of the relationships previously mentioned. For example, areas in which nodules have high cobalt contents are found mainly at relatively shallow depths in the central Pacific. Nodules having high nickel and copper contents occur mainly at abyssal depths at low latitudes. The ClarionClipperton zone in the northeastern equatorial Pacific represents the largest accumulation yet known of nodules averaging 1.8 percent combined nickel and copper or more. Similar types also are 
present in the southeastern equatorial Pacific and the equatorial part of the Indian Ocean, but nodules having high combined nickel and copper contents also occur at higher latitudes. Nearly all of the stations at which high manganese contents have been found are in the eastern and northern equatorial Pacific.

The data on high cobalt and high manganese types are not sufficient to justify an attempt to delineate the areas in which they are found as targets for exploration, although the data available would help in selecting regions where deposits of those types might be sought. Rough exploration targets for nodules having high combined nickel and copper contents have been delineated, however, and indicate several large areas where exploration might be justified later on.

Nearly 60 chemical elements have been found in subsea manganese nodules, many in concentrations far exceeding their average abundances in the Earth's crust. Variations in the concentrations of many of these elements with latitude, depth, and metal type follow the principal metals. For example, the highest means for magnesium, scandium, chromium, and zinc are found in nodules containing more than 1.8 percent combined nickel and copper; the highest means for phosphorus, titanium, vanadium, calcium, strontium, yttrium, zirconium, lanthanum, cerium, and lead are found in nodules containing more than 0.5 percent cobalt; the highest means for sodium and lead are found in nodules containing more than 35 percent manganese. However, the nodule groups having high combined nickel and copper, cobalt, and manganese contents do not include the maximum values for several other elements, such as titanium (8.9 percent), vanadium (0.5), zinc (9.0), and lead (0.75). Many of these maximums are higher than the means by an order of magnitude or more and may represent analytical errors. That this explanation may not hold, however, is suggested by the fact that the maximum for each ocean is also much higher than the world mean. The world maximum for zinc, for example, is from the Indian Ocean, but the high values in the Atlantic and Pacific Oceans are 8.0 and 7.0 percent, respectively. It seems possible, therefore, that types of metal-rich nodules other than those discussed here may exist and that some of them may be of potential economic value. Some minor metals in nodules rich in combined nickel and copper and in cobalt may also prove to be recoverable as coproducts.
Molybdenum and vanadium, for example, would seem to be candidates for recovery from nodules in the Clarion-Clipperton zone.

Not many samples have been analyzed for precious metals, but the few analyses available indicate that some are present in amounts much higher than their average abundances in the Earth's crust, although they are still too low to be of primary economic value. Platinum, for example, has been found in a sample from the ClarionClipperton zone and in one from the Blake Plateau in amounts of 123 and $453 \mathrm{ppb}$, respectively.

Many of the variations in the composition of manganese nodules are reflected in their mineralogy. It is now well established that the nodules are mixtures of three manganese mineral phases (vernadite, todorokite, and birnessite), an amorphous iron oxide phase, phillipsite, and admixed clay and other silicate minerals from extraneous sources. Fine-grained manganese and iron oxides have the capacity to attract and hold by physical adsorption a wide variety of metals; in addition, the crystal structures of todorokite and birnessite have sites in which small divalent cations such as nickel and copper can replace $\mathrm{Mn}^{+2}$ and other sites that will accommodate large cations such as potassium. It has also been established that todorokite forms on the parts of nodules that are buried in the uppermost layer of sediments as a result of diagenetic processes in which manganese (but not iron) is dissolved under the reducing conditions prevailing in the sediments (perhaps created by decaying organic matter), carried upward, and precipitated under the oxidizing conditions prevailing on the sea bottom. The amorphous iron-vernadite phases are direct precipitates from seawater and form on the tops of nodules exposed to seawater or as crusts on bedrock surfaces where there are no nucleating grains. Both groups of minerals form in the same macroenvironment of the deep ocean floor, and the mineral composition of a nodule thus depends on its exposure to seawater, as opposed to sediment in which diagenetic processes are operating. That fact alone does not explain the regional variations in nodule composition, however, for the nickel and copper contents of todorokite vary considerably.

Many factors may play a part in the origin and composition of the nodules, and combinations of these factors seem to explain at least partly some of their variations. For example, the high cobalt content of western Pacific nodules may be related 
to the highly oxidizing, essentially nondepositional environment prevailing on the extensive seamounts and plateaus in that area. The circumferential and latitudinal variations may be related to oceanic circulation, which creates areas of high organic productivity along the eastern sides of the basins in each hemisphere and along the equatorial countercurrent and results in a slowly accumulating, widespread blanket of sediments on the abyssal floor. The regional variation in the character of this blanket depends on the dominance of biogenous, pelagic, or terrigenous sediments in which diagenetic processes are active in mobilizing and partitioning metals. The differences in the average compositions of the nodules from ocean to ocean may relate to major differences in their geology and morphology. The Atlantic, for example, receives much more terrigenous matter per unit of area than the Pacific, its abyssal plains are proportionately less extensive, and its mean depth is 10 percent less - all factors that would help account for its lower average manganese, nickel, and copper contents. But a better understanding of ocean processes and regional oceanography and geology is required to explain all the variations observed in the composition of subsea manganese nodules.

\section{REFERENCES CITED}

Andrews, J. E., Pautot, G., and Friedrich, G., 1980, Results evaluation of hypotheses concerning nodule growth [abs.]: International Geological Congress, 26th, Paris 1980, Resumes, no. 26, v. 3, p. 897.

Arrhenius, G., 1975, Mineral resources of the ocean floor, in The new wave in the earth sciences: Cambridge, Massachusetts Institute of Technology, $77 \mathrm{p}$.

Barnes, S. S., 1967, Minor element composition of ferromanganese nodules: Science, v. 157, p. 63-65.

Bender, M. L., 1971, Does upward diffusion supply the excess manganese in pelagic sediments?: Journal of Geophysical Research, v. 76, p. 4212-4215.

Bender, M. L., and Gagner, C., 1976, Dissolved copper, nickel, and cadmium in the Sargasso Sea: Journal of Marine Research, v. 34, p. 327-339.

Bender, M. L., Klinkhammer, G. P., and Spencer, D. W., 1977, Manganese in seawater and the marine manganese balance: Deep-Sea Research, v. 24, p. 799-812.

Bischoff, J. L., Piper, D. Z., and Leong, K., 1981, The aluminosilicate fraction of north Pacific manganese nodules: Geochimica et Cosmochimica Acta, v. 45, p. 2047-2063.

Borchert, H., 1970, On the ore-deposition and geochemistry of manganese: Mineralia Deposita, v. 5, p. 300-314.

Burns, R. G., 1965, Formation of Co (III) in the amorphous $\mathrm{FeOOH} n \mathrm{H}_{2} \mathrm{O}$ phase of manganese nodules: Nature, v. 205, p. 999 .
1976, The uptake of cobalt into ferromanganese nodules, soils, and synthetic manganese (IV) oxides: Geochemica et Cosmochimica Acta, v. 40, p. 95-102.

Burns, R. G., and Burns, V. M., 1977, Mineralogy of manganese nodules, in Glasby, G. B., ed., Marine manganese deposits: New York, Elsevier, p. 185-248.

-1979, Manganese oxides, in Burns, R. G., ed., Marine minerals: Mineralogical Society of America Reviews in Mineralogy, v. 6, p. 1-46.

Burns, R. G., and Fuerstenau, D. W., 1966, Electroprobe determination of inter-element relationships in manganese nodules: American Mineralogist, v. 51, p. 895-902.

Buser, W., and Grutter, A., 1956, Uber die Natur de Manganknollen: Schweizerische Mineralogische und Petrograpische Mitteilungen, v. 36, p. 49-62.

Calvert, S. E., 1978, Geochemistry of oceanic ferromanganese deposits: Philosophical Transactions of the Royal Society of London, v. 290A, no. 1366, p. 43-73.

Calvert, S. E., and Price, N. B., 1977, Geochemical variation in ferromanganese nodules and associated sediments from the Pacific Ocean: Marine Chemistry, v. 5, p. 43-74.

Cheney, E. S., and Vredenburgh, L. D., 1968, The role of iron sulfides in the diagenetic formation of iron poor manganese nodules: Journal of Sedimentary Petrology, v. 38, p. 1363-1365.

Chukhrov, F. V., Gorshkov, A. I., Beresovskaya, V. V., and Sivtosov, A. V., 1979, Contributions to the mineralogy of authigenic manganese phases from marine manganese deposits: Mineralia Deposita, v. 14, p. 249-261.

Crerar, D. A., and Barnes, H. L., 1974, Deposition of deep-sea manganese nodules: Geochimica et Cosmochimica Acta. v. 38, p. 279-300.

Cronan, D. S., 1967, The geochemistry of some manganese nodules and associated pelagic sediments: Unpublished Ph.D. thesis, University of London.

1975, Manganese nodules and other ferromanganese deposits from the Atlantic Ocean: Journal of Geophysical Research, v. 80, p. 3831-3837.

-1976, Manganese nodules and other ferromanganese oxide deposits, in Riley, J. P., and Chester, R., eds., Chemical oceanography: London, Academic Press, v. 5, p. 217-263.

1977, Deep-sea nodules: Distribution and geochemistry, in Glasby, G. P., ed., Marine manganese deposits: Amsterdam, Elsevier, p. 11-44.

1980, Underwater minerals: London, Academic Press, 362 p.

Cronan, D. S., and Tooms, J. S., 1969, The geochemistry of manganese nodules and associated pelagic deposits from the Pacific and Indian Oceans: Deep-Sea Research, v. 16, p. 335-359.

Exon, N. F., 1981, Manganese nodules in the Cook Islands region, Southwest Pacific: South Pacific Marine Geological Notes, v. 2, no. 3, p. 47-65.

-1982, Manganese nodules in the Kiribati region, equatorial western Pacific: South Pacific Marine Geological Notes, v. 2, no. 3, p. 77-102.

Flanagan, F. J., and Gottfried, D., 1980, USGS rock standards III: Manganese nodule reference samples USGS-Nod-A-1 and USGS-Nod-P-1: U.S. Geological Survey Professional Paper 1155, 39 p.

Fleischer, M., 1980, Glossary of mineral species, 1980: Tucson, Mineralogical Record, 192 p. 
Frazer, J. Z., and Fisk, M. B., 1980, Availability of copper, nickel, cobalt, and manganese from ocean ferromanganese nodules (III): La Jolla, Calif., Scripps Institution of Oceanography, S10 reference 80-16 (prepared for U.S. Bureau of Mines), $117 \mathrm{pp}$.

Glasby, G. P., 1981, Manganese nodule studies in the Southwest Pacific: South Pacific Marine Geological Notes, v. 2, no. 3, p. 37-46.

Goldberg, E. D., 1954, Marine geochemistry, pt. I, Chemical scavengers of the sea: Journal of Geology, v. 62, p. 249-265.

-1961, Chemistry in the oceans, in Sears, M., ed., Oceanography: American Association for the Advancement of Science Publication 67, p. 583-597.

1965, Minor elements in sea water, in Riley, J. P., and Skirrow, G., eds., Chemical oceanography: London, Academic Press, v. 1, p. 163-196.

Goldberg, E. D., Broecker, W. S., Gross, M. G., and Turekian, K. K., 1971, Radioactivity in the marine environment: Washington, D.C., Committee on Oceanography, National Academy of Science-National Research Council, p. 137-146.

Goldschmidt, V. M., 1954, Geochemistry: London, Oxford University Press, 730 p.

Greenslate, J. L., 1975, Manganese-biota association in northeast Pacific sediments: Unpublished Ph.D. thesis, University of California, San Diego.

Greenslate, J. L., Frazer, J. Z., and Arrenhius, G., 1973, Origin and deposition of selected transition elements in the seabed, in Morgenstein, M., ed., Papers on the origin and distribution of manganese nodules in the Pacific and prospects for exploration: Honolulu, Hawaii Institute of Geophysics, p. 45-70.

Halbach, P., and Fellerer, R., 1980, The metallic minerals of the Pacific seafloor: Geojournal, v. 4, no. 5, p. 407-422.

Halbach, P., and Ozkara, M., 1979, Morphological and geochemical classification of deep-sea ferromanganese nodules and its genetical interpretation: Colloques International du Centre National de la Recherche Scientifique, no. 289, p. 77-88.

Halbach, P., Rehm, E., and Marchig, V., 1979, Distribution of $\mathrm{Si}, \mathrm{Mn}, \mathrm{Fe}, \mathrm{Ni}, \mathrm{Cu}, \mathrm{Co}, \mathrm{Zn}, \mathrm{Pb}, \mathrm{Mg}$, and $\mathrm{Ca}$ in grain-size fractions of sediment samples from a manganese nodule field in the central Pacific Ocean: Marine Geology, v. 29, p. 237-252.

Harriss, R. C., Crocket, J. H., and Stainton, M., 1968, Palladium, iridium, and gold in deep-sea manganese nodules: Geochimica et Cosmochimica Acta, v. 32, p. 1049-1056.

Heath, G. R., 1981, Ferromanganese nodules of the deep sea, in Skinner, B. J., ed., Economic geology - 75th anniversary volume, 1905-1980: El Paso, Economic Geology Publishing Co., p. 735-765.

Hein, P., 1977, Geochimie des nodules du Pacifique nord-est, étude statistique: Centre National pour l'Exploitation des Oceans Rapports Scientifiques et Techniques no. 35, 74 p.

Hewett, D. F., Fleischer, M., and Conklin, N., 1963, Deposits of the manganese oxides [supplement]: Economic Geology, v. 58, p. $1-51$.

Heye, D., and Marchig, V., 1977, Relationship between the growth rate of manganese nodules from the Central Pacific and their chemical constitution: Marine Geology, v. 23, p. M19-M25.
Horn, D. R., Horn, B. M., and Delach, M. N., 1972, Ferromanganese deposits of the North Pacific: National Science Foundation, Office of International Decade of Ocean Exploration Technical Report 1, 78 p.

Horn, D. R., Delach, M. N., and Horn, B. M., 1973, Metal content of ferromanganese deposits of the oceans: National Science Foundation, Office of International Decade of Ocean Exploration Technical Report 3, 51 p.

Howarth, R. J., Cronan, D. S., and Glasby, G. P., 1977, Nonlinear mapping of regional geochemical variability of manganese nodules in the Pacific Ocean: Transactions of the Institution of Mining and Metallurgy, v. 86, p. 134-138.

Hutchinson, G. E., 1947, The problems of ocean geochemistry: Ecological Monographs, v. 17, p. 299-307.

Lee, Tan, and Yao, Chi-lung, 1970, Abundance of chemical elements in the earth's crust and its major tectonic units: International Geology Review, v. 12, p. 778-786.

Lisitzin, A. P., 1972, Sedimentation in the world oceans: Society of Economic Paleontologists and Mineralogists Special Publication 17, 218 p.

Lynn, D. C., and Bonatti, E., 1965, Mobility of manganese in diagenesis of deep-sea sediments: Marine Geology, v. 3, p. 457-474.

Manheim, F. T., 1965, Manganese-iron accumulations in the shallow marine environment, in Schink, D. R., and Corliss, J. T., eds., Symposium on marine geochemistry: University of Rhode Island Graduate School of Oceanography, Narragansett Marine Laboratory Occasional Publication 3, p. 217-276.

Manheim, F. T., Aruscavage, P. J., Simon, F. O., and Wu, C. C., 1980, Composition and mineralogy of western Atlantic ferromanganese nodules, with special emphasis on platinum metals [abs]: International Geological Congress, 26th, Paris 1980, Resumes, no. 26 , v. 3, p. 966.

Manheim, F. T., Halbach, P., Woo, C. C., and Commeau, R. F., 1982, Economic significance of ferromanganese crusts on seamounts of the Mid-Pacific area [abs.]: Geological Society of America Abstracts with Programs, v. 14, no. 7, p. 555.

Margolis, S. V., and Burns, R. G., 1976, Pacific deep-sea manganese nodules: Their distribution, composition and origin: Annual Review of Earth and Planetary Science, v. 4, p. 229-263.

McKelvey, V. E., and Wright, N. A., 1980, Metal content of manganese nodules in part of the southeastern equatorial Pacific: U.S. Geological Survey Open-File Report 80-373, 24 p.

McKelvey, V. E., Wright, N. A., and Rowland, R. W., 1979, Manganese nodule resources in the northeastern equatorial Pacific, in Bischoff, J. L., and Piper, D. Z., eds., Marine geology and oceanography of the Pacific manganese nodule province: New York, Plenum, p. 747-762.

Menard, H. W., 1964, Marine geology of the Pacific: New York, McGraw-Hill, 271 p.

-1976, Time, chance, and the origin of manganese nodules: American Scientist, v. 64, p. 519-529.

Menard, H. W., and Frazer, J. Z., 1978, Manganese nodules on the sea floor: Reverse correlation between grade and abundance: Science, v. 199, p. 969-971.

Mero, J. L., 1962, Ocean-floor manganese nodules: Economic Geology, v. 57, p. 747-767.

1965, The mineral resources of the sea: Amsterdam, Elsevier, 312 p. 
Pautot, G., and Melguen, M., 1979, Influence of deep water circulation and sea floor morphology on the abundance and grade of central south Pacific manganese nodules, in Bischoff, J. L., and Piper, D. Z., eds., Marine geology and oceanography of the Pacific manganese nodule province: New York, Plenum, p. 621-649.

Pautot, G., Hoffert, M., Karpoff, A., and Schoaf, A., 1978, Le Bassin de Tiki (Pacifique Sud Central): Relations entre composition-distribution des nodules et profondeurmorphologie du fond: Colloque International du Centre National de le Recherche Scientifique no. 289, p. 113-118.

Piper, D. Z., 1972, Rare elements in manganese nodules from the Pacific Ocean, in Horn, D. R., ed., Ferromanganese deposits on the ocean floor: Washington, D.C., National Science Foundation, p. 123-130.

1974, Rare earth elements in manganese nodules and other marine phases: Geochimica et Cosmochimica Acta, v. 38, p. 1007-1022.

Piper, D. Z., and Williamson, M. E., 1977, Composition of Pacific Ocean ferromanganese nodules: Marine Geology, v. 23, p. 285-303.

Piper, D. Z., Leong, K., and Cannon, W. F., 1979, Manganese nodules and surface sediment compositions: DOMES sites A, B, and C, in Bischoff, J. L., and Piper, D. Z., eds., Marine geology and oceanography of the Pacific manganese nodule province: New York, Plenum, p. 437-473.

Piper, D. Z., Swint, T. R., McKelvey, V. E., and Sullivan, L., 1982, Distribution of manganese nodules in the Pacific Ocean [abs.]: Circum-Pacific Energy and Mineral Resources Conference, 1982, Abstracts of Papers, p. 41.

Price, N. B., and Calvert, S. E., 1970, Compositional variation in the Pacific Ocean ferromanganese nodules and its relationship to sediment accumulation rates: Marine Geology, v. 9, p. 145-171.

Rabb, W., 1972, Physical and chemical features of Pacific deep sea manganese nodules and their implications to the genesis of nodules, in Horn, D. R., ed., Ferromanganese deposits on the ocean floor: Washington, D.C., National Science Foundation, p. 31-49.

Ramberg, H., 1952, The origin of metamorphic and metasomatic rocks: Chicago, University of Chicago Press, 317 p.

Renard, D., Michard, G., and Haffert, M., 1976, Comportment geochimique du nickel et du cobalt a linterface eausediment: Application a Yenrichissement en ces elements dans les formations ferromanganiferes: Mineralia Deposita, v. 11 , p. 380-393.

Skornyakova, N. S., 1965, Dispersed iron and manganese in Pacific Ocean sediments: International Geology Review, v. 7, p. 2161-2174.

1976, Chemical composition of ferromanganese nodules of the Pacific: Transactions of the Academy of Sciences of the U.S.S.R., P. P. Shirshov Institute of Oceanography, v. 109 , p. $190-240$.

1979, Zonal regularities in occurrence, morphology, and chemistry of manganese nodules of the Pacific Ocean, in Bischoff, J. L., and Piper, D. Z., eds., Marine geology and oceanography of the Pacific manganese nodule province: New York, Plenum, p. 699-728.

Straczek, J. A., Horen, A., Ross, M., and Warshaw, C. M., 1960, Studies of the manganese oxides, pt. IV, Todorokite: American Mineralogist, v. 45, p. 1174-1184.

Tooms, J. S., Summerhayes, C. P., and Cronan, D. S., 1969, Geochemistry of marine phosphate and manganese deposits: Oceanography and Marine Biology Annual Review, v. 7, p. 49-100.

Usui, A., 1979, Minerals, metal contents, and mechanisms of formation of manganese nodules from the central Pacific basin (GH 76-1 and GH 77-1 Areas), in Bischoff, J. L., and Piper, D. Z., eds., Marine geology and oceanography of the Pacific manganese nodule province: New York, Plenum, p. 651-679.

Wendt, J., 1974, Encrusting organisms in deep-sea manganese nodules: International Association of Sedimentologists Special Publication 1, p. 437-447. 